\title{
Planeamiento y geometría en la Ciudad Medieval Aragonesa
}

\author{
Ramón Betrán Abadía*
}

\begin{abstract}
RESUMEN
El texto analiza las técnicas urbanísticas empleadas para la producción de la ciudad medieval aragonesa. Por razones de espacio, solamente se estudian las poblaciones debidas a un planeamiento consciente y dotadas de un orden geométrico. Con esta premisa, se integran los sucesivos episodios analizados -incluidas las más remotas planificaciones islámicas- en un intento de comprensión evolutiva del fenómeno urbano y de su dependencia de las necesidades espaciales de una formación social cambiante.
\end{abstract}

PALABRAS CLAVE: Ciudad medieval, urbanismo, urbanismo islámico

\section{REGULARIDAD Y PLANEAMIENTO URBANO}

En su diálogo Eupalinos ou l'Architecte ( 192 I), Paul Valéry hace que Sócrates le pida a Fedro que trace en la pared, en un solo movimiento, «cualquier rasgo sin pensar en él.» Fedro dibuja algo parecido a «una línea de humo [...] [que] rinde la imagen de un capricho sin objeto, sin principio ni fin, ni más sentido que la libertad de mi ademán en el radio de mi brazo.») La geometría es para Valéry un producto de la educación, en cierto modo contrario a la naturaleza espontánea del hombre. Pero Le Corbusier

\begin{abstract}
This paper focuses on the urbanistic techniques used to produce the medieval towns in Aragon. Due to the lack of room, only the ones conceived under an explicit planning, so exhibiting a geometrical order, are studied. The different and correlative chronological episodes -the earliest islamic foundations included- are put togheter with the aim of understanding the evolution of urban phenomenon, and its dependency from the spatial needs of an ever-changing social formation.
\end{abstract}

KEY WORDS: Medieval town, town planning, islamic urbanism

opina todo lo contrario, y en El Espíritu Nuevo en Arquitectura (1924), responde al pasaje anterior del Eupalinos:

«No se admitirá sin extrañeza que tal sea el gesto inicial de un hombre. Para mí, que no soy filósofo, que soy simplemente un ser activo, me parece que este gesto primero no puede ser vago, que en el mismo nacimiento, en el momento cuando los ojos se abren a la luz, surge inmediatamente una voluntad: si me hubiesen dicho que trazase algo sobre una pared, me parece que habría trazado una cruz, que está hecha de cuatro ángulos rectos, que es una perfección

* Arquitecto. Ayuntamiento de Zaragoza. 
que lleva en sí algo divino y que es, al mismo tiempo, una toma de posesión de mi universo, porque en los cuatro ángulos rectos tengo los dos ejes, apoyo de las coordenadas con las que puedo representar el espacio y medirlo.ly

Le Corbusier tenía razón. Los más remotos asentamientos urbanos de que tenemos noticia son otras tantas pruebas de la asociación de planificación y regularidad. En el muro de lo que pudo ser un santuario en la más antigua ciudad conocida, Çatal Hüyük, subsiste un fresco, fechado en el 6200 a.e., que representa la ciudad como una retícula con manzanas casi cuadradas. No nos interesa tanto la veracidad de la imagen, ciertamente muy idealizada, como el modo en que sus habitantes deseaban verla.

La mayoría de los asentamientos urbanos carecen de regularidad geométrica, pero no de orden; cuando la regularidad falta es porque no se verifican sus condiciones objetivas, pero nunca por una valoración favorable de la irregularidad. Hasta mediados del siglo XVIII, cuando la burguesía invente el derecho natural y formule la teoría del contrato social, no se formulará ninguna teoría urbanística que defienda positivamente los valores del pintoresquismo y de la sorpresa.

Las primeras religiones institucionalizadas de Oriente Próximo concibieron un universo sujeto a un rígido orden geométrico, impuesto penosamente por los dioses creadores al caos primigenio, del mismo modo en que los reyes disponían la colonización de un territorio o la fundación de una ciudad. Las primeras ciuda- des, residencias del poder, se presentaban como imágenes del Cosmos, sujetas a su mismo orden y con una lectura simbólica superpuesta a su funcionalidad inmediata, que reforzaba la idea del rey como imagen de los dioses.

\section{Dos modalidades de planificación geométrica}

En las agrupaciones de edificios monumentales, los egipcios emplearon rígidas geometrías simbólicas pretendidamente sujetas al orden del universo, para manifestar la relación entre el poderoso y la divinidad. En los asentamientos residenciales, emplearon otra forma de geometría, emparentada con la agrimensura, cuyo único fin era resolver un problema práctico de distribución del suelo según criterios de funcionalidad y adecuación al estatuto social -igualitario o no- de los destinatarios de las parcelas '.

En Mesopotamia y en Persia se erigieron raras pero significativas ciudades circulares, tipo urbano ausente en Egipto, en el que la totalidad urbana simboliza el orden cósmico centrado en el soberano, mediante procedimientos proyectuales elaborados por sacerdotes versados en matemáticas y astrónomía; el orden rígido impuesto a la ciudad revela un férreo dominio de las clases dirigentes. A esta familia pertenecieron la ciudad hitita de Sendschirli ${ }^{2}$, Darad (Darabjerd) ${ }^{3}$ y Ecbatana ${ }^{4}$. De ellas derivaron las ciudades utópicas descritas por Platón en Leyes y en Critias, y, ya en el siglo VIII, Bagdag, ombligo del mundo en cuyo centro el califa ejercía un poder absoluto y universal ${ }^{5}$.

\footnotetext{
I Un ejemplo de este tipo de núcleos es el-Lahun (actual Kahun), creado ex novo para alojar a los sacerdotes y a los obreros cualificados que participaron en la construcción de la pirámide de Sesostris || (I897-|879 a.e.); a pesar de que todas las viviendas eran modulares, las de los sacerdotes y capataces eran mayores que las de los obreros.

2 Su doble muralla, perfectamente circular y con tres puertas conformando un triángulo equilátero ideal, encierra un montículo coronado por el palacio real, también fortificado aunque con el perímetro oval irregular de la meseta que ocupa.

3 Tal vez fundada por Darío, como una fortaleza circular rodeada con una muralla concéntrica, también circular, con ocho puertas equidistantes.

4 La persa Hagamatana, construida por el rey medo Deyoces, «prendado del poder absoluto», y descrita por Heródoto (Historia I, 98 100) como un palacio real rodeado por una muralla circular dorada, rodeado, a su vez, por otras seis murallas concéntricas, cada una de un color.

5 Fundada en el 762 por el califa cabbāsí Abū Ŷacfar al-Mansūr. Era un círculo perfecto de 530 hectáreas de superficie, rodeado por tres muros defensivos concéntricos, con cuatro puertas fortificadas orientadas a los puntos cardinales. En el centro se emplazaban el palacio califal y la Gran Mezquita, en medio de una inmensa área circular ajardinada de 1.500 metros de diámetro.
} 
Un bajorrelieve neoasirio procedente de la sala del trono del palacio de Assurbanipal en Nimrud (ca. 900 a.e.) representa una ciudad como un círculo almenado en el que se inscribe una cruz que lo divide en cuatro cuarteles iguales, donde se representan personajes que ejercen otros tantos oficios; recuerda el jeroglifo egipcio nywt $(\oplus)$, indicativo de la ciudad, y el carácter cuneiforme sumerio er, ur, «ciudad», formado por los cinco trazos correspondientes a los lados de un cuadrado girado $45^{\circ}$ y su diagonal vertical. Un emblema igual al nywt representaba al cosmos en Roma, y su traslación urbana se realizó en las colonias provinciales, donde se repitió una y otra vez la instauratio -orientatio y delimitatio-, el rito de la fundación de la Roma Quadrata descrito por Plutarco en su Vida de Rómulo.

Aun con una estructura ortogonal, la asiria Babilonia, dominada por el célebre zigurat de siete pisos de otros tantos colores - uno por planeta, con el sol en la cúspide-, participó de la intención simbólica de las ciudades circulares. Al menos en la idealización transmitida por el Enuma Elish y Heródoto, Babilonia representa al mundo, es la Casa de la Totalidad, con dos ejes primordiales en cruz que dividen la planta cuadrada -la tierra emergente- en cuatro cuarteles correspondientes a las cuatro regiones del universo; alrededor de su muralla, el Éufrates y el foso rememoran el medio acuático primigenio del que nació el mundo y que rodea la tierra emergente.

\section{Regularidad y propiedad del suelo}

La ciudad regular es posible cuando lo es el planeamiento y el urbanista goza de la libertad necesaria. Además de unas condiciones materiales adecuadas (terreno Ilano, suelo homogéneamente resistente, ausencia de pre- existencias...) son necesarias las prerrogativas de la propiedad. En la ciudad precapitalista, esta condición se verificaba en contadas ocasiones: en los estados teocráticos, cuando prevalecía el derecho de conquista o en fundaciones sobre suelo perteneciente al fundador.

Las realizaciones urbanas más regulares y racionales que ha dado la historia se produjeron donde se hizo tabla rasa de los derechos adquiridos. Juvenal y Séneca describieron una caótica Roma - donde existía la propiedad ex iure Quiritium-, pero los romanos realizaban ordenaciones cartesianas en las ciudades y campos provinciales, donde todo el suelo era ager publicus por conquista.

Las grandes ciudades medievales eran irreductibles a un orden geométrico global ${ }^{6}$, pero las bastidas y pequeñas poblaciones fundadas sobre territorios reconquistados alcanzaban un alto grado de regularidad. En los suelos de realengo, de señores territoriales o sometidos a derecho de conquista los urbanistas de la Edad Media pudieron concentrar su atención en los requerimientos de la ciudad, sobre la base del borrón y la cuenta nueva.

El Renacimiento hubo de limitarse en las capitales europeas a abrir plazas y enderezar calles, mientras en América y en las ciudadelas militares podía producir trazados urbanos tan perfectos como los dibujados en los tratados contemporáneos de arquitectura.

La urbanización acometida en las ciudades europeas durante el siglo $X X$, gestionada por expropiación sistemática, ha producido barrios mucho más ordenados que la aplicación de las complejas técnicas de autogestión, sobre todo la compensación, en la urbanización periférica española.

6 Aunque se imprimieron las huellas geométricas del poder -o de los poderes- en los órdenes radiocéntricos, centrados en la catedral, de las parroquias y de los conventos mendicantes; en la disposición de las sedes del gobierno, de las instituciones ciudadanas y, desde el final del Medievo, de los palacios de la nobleza; en la adición de barrios planeados y, a su manera, en la formación de los guetos consiguientes a los concilios tercero y cuarto de Letrán. Por razones de espacio limitaremos este trabajo al estudio del orden geométrico del plan urbanístico, con exclusión de las actuaciones sectoriales que imprimieron a las ciudades medias y grandes su característico orden complejo. 


\section{ORGANIZACIÓN Y REGULARIDAD EN LA CIUDAD ISLÁMICA}

Todo lo dicho vale también para entender la ciudad islámica. La característica forma laberíntica de su estado maduro no expresa desorden, sino el orden que corresponde a unas específicas formas de asentamiento por tribus, clanes o familias extensas, a una titularidad fragmentaria del suelo y del vuelo, y a la predominancia de las normas del derecho privado sobre un inexistente derecho público urbanístico. Desde hace décadas se abre paso la idea de que, en un primer momento, muchas fundaciones urbanas islámicas se atuvieron a trazados ortogonales $\mathrm{O}$, al menos, marcadamente regulares, y que fue su evolución posterior, sujeta a los avatares del derecho civil islámico, la que las llevó a la irregularidad laberíntica que conocemos $^{7}$.

La tortuosidad y la angostura del sistema viario en la ciudad musulmana, y la privatización de algunas de sus partes funcionales, se iban produciendo por el juego de unas cuantas normas jurídicas civiles aplicadas a lo largo del tiempo al albur de cada situación particular:

- En razón de la autonomía jurídica de la familia en un estado concebido como confederación de clanes, en el Islām prevaleció lo privado sobre lo público. En rigor, no existía la propiedad privada del suelo en un sentido parecido a la plena propiedad burguesa, aunque, en la práctica, todo funcionara como si la hubiera ${ }^{8}$. Una familia podía acceder al disfrute exclusivo de un suelo por adquisición (compra, herencia...), de hecho o por reconocimiento del derecho de uso preferente. En estos dos últimos casos, desde el acceso a la posesión (yad) operaba un plazo ${ }^{9}$ cuyo transcurso pacífico implicaba la usucapión o prescripción adquisitiva (hìyāza). Sobre el fundo así adquirido operaba un derecho casi intocable (milk $)^{10}$, que incluía la más absoluta libertad de disposición de su titular ${ }^{\prime \prime}$.

- El propietario de una casa gozaba del derecho de uso preferente de la franja de calle que discurría ante el muro donde se abría su puerta (finā'), de cuya limpieza y cuidado era responsable. Ahí, los habitantes de la vivienda salían a sentarse, ataban sus animales, extendían tenderetes -en principio provisionales- para vender sus mercancías, cargaban y descargaban, vertían las aguas de la casa, proyectaban toldos o balcones, dejaban su basura... (BRUNSCHVIG 1947: 133134; VAN STAËVEL 200 I: 234-235; GARCÍABELLIDO 1997: 69). A veces, sobre esta incierta franja de servidumbre ampliaban

\footnotetext{
7 La conciencia que los responsables de la planificación hubieron de tener de la precariedad de la trama ordenada permite suponer que, salvo que imperaran razones propagandísticas, se obsesionarían menos por la perfección geométrica que por la eficacia de reparto. Tampoco debe desestimarse que muchas de las transformaciones consistentes en estrechamientos e interrupciones de calles pasantes, convertidas en adarves, se produjeran ya en el momento de la materialización del plan. En los análisis que conozco de la mutación de las tramas malladas islámicas hacia las arborescentes se ha puesto demasiado énfasis en la evolución a medio y largo plazo, y se ha pasado por alto que hubieron de producirse transformaciones importantes en el mismo momento (entiéndase por tal un período de tiempo más o menos largo) en que, sobre una trama sólo replanteada en el terreno (fuera o no la traslación de un plan trazado sobre el papel), los beneficiarios de las parcelas construyeron sus casas. Sería entonces cuando los futuros habitantes podrían acordar, dentro de los límites de sus respectivos intereses y al amparo del carácter consensuado del derecho islámico, la privatización de determinados espacios teóricamente destinados a viales, de modo que algunas de las calles pasantes quedarían reducidas a adarves y no pocas se estrecharían, continuándose en lo sucesivo el proceso con el motor, sobre todo, de las sucesivas particiones del parcelario. Probablemente, serían más frecuentes en adelante los nuevos adarves formados por perforación de manzanas para acceder a parcelas interiores segredadas de otras mayores, que por estrangulamiento de anteriores calles pasantes.

8 Salvo por la preeminencia en el Islām del uso sobre el título.

9 Al parecer, 10 años sobre suelos privados y 20 sobre vías públicas (VAN STAËVEL 1995: 57).

IO Lo que no excluía que, aun con reticencias doctrinales, el Islām conociera la expropiación forzosa ( $\hat{y} a b r a n$ šarciyyan y, por supuesto, la adquisición en avenencia, bien documentadas en la creación y ampliación de mezquitas y cementerios públicos, apertura de calles y caminos, y otras obras de indudable interés público. Junto a las adquisiciones con justa compensación económica, operó con cierta frecuencia la confiscación de bienes por el estado bajo acusación de rebeldía.

I। El derecho a vender el suelo adquirido dio lugar a un activo mercado de bienes raíces, registrados en un catastro público (zimām
} al-bilād); en la compra de suelo y casas se invertían aquellos excedentes de capital deseosos de valores seguros. 
abusivamente la casa, provocando su privatización de hecho y el consiguiente estrechamiento de la calle. Operaba entonces el principio alcoránico «lā ḍărar wa-lā ḍirān» («ningún daño entre vosotros»)), pieza fundamental del derecho māliki para intervenir en la dinámica urbana, que prohibía con carácter general hacer uso del derecho propio con el único objeto de perjudicar a otros o causar un daño desproporcionado con el beneficio obtenido. Aunque la ocupación abusiva de la calle fue reiteradamente prohibida por el derecho musulmán, con esa base la autoridad sólo actuaba contra el infractor si la invasión reducía su anchura libre por debajo del umbral estrictamente exigido por la circulación ${ }^{12}$, o si se causaba un perjuicio objetivo a un vecino y éste lo denunciaba; sólo entonces podía ordenar la demolición de la construcción ilegal. Si, como era mucho más frecuente, se aceptaba el hecho consumado, al cabo de 10 ó 20 años el suelo quedaba incorporado por usucapión al patrimonio del infractor. Con tan simples principios, la calle era presionada aleatoria y multilateralmente por invasiones de las casas, bien ocupando directamente el suelo, bien volando saledizos y pasadizos sobre ellas.

- En lugar de preservarse los inmuebles urbanos indivisos, como ocurría en la villa feudal de fundación ${ }^{13}$, el sistema hereditario musulmán producía un fraccionamiento progresivo y exhaustivo de la propiedad, que se iba dividiendo con la sucesión de las generaciones para dar lugar a un minifundismo urbano. En el Islām, sólo un tercio de los bienes podía ser objeto de legación testamentaria a voluntad del titular; la herencia de los otros dos tercios se resolvía en un complejo reparto entre los parientes, tasado en función de su grado de parentesco.
Los bienes inmuebles no gozaban de ninguna especificidad, de modo que, lejos de instituciones del tipo del hereu aragonés, los fundos rústicos y urbanos tendieron pulverizarse en sucesivas herencias. Tras unas pocas generaciones, las manzanas urbanas quedaban fragmentadas en gran cantidad de parcelas de tamaño mínimo, muchas interiores y sin fachada ni acceso directo desde las calles que inicialmente la delimitaban. Consecuentemente, junto con las nuevas parcelas iban apareciendo los adarves y pasajes necesarios para llegar hasta ellas. Aunque las calles primitivas hubieran sido públicas, los nuevos callejones eran ya de propiedad privada. Este complicado sistema de herencia no sólo trituraba el suelo, sino también el vuelo, de modo que las casas se fragmentaban por pisos y habitaciones, y eran impulsadas a elevarse cada vez más para posibilitar nuevas divisiones interiores, o a proyectarse fuera de sus fachadas en saledizos, ajimeces o vuelos que apuraban al máximo las posibilidades de privatización de calles y adarves, y terminaron por cubrir tramos enteros, convertidos en túneles lóbregos y húmedos. Dentro de cada casa aparecían retorcidos pasillos que llevaban a las distintas heredades.

Los descubrimientos arqueológicos recientes y la persistencia inalterada de las fundaciones áulicas ordenadas sobre rígidas geometrías ('Anyar, Ayla, Bagdag, Sāmarrā', Madīnat al-Zahrā'), permiten imaginar el efecto distorsionante que tuvo la dinámica urbanística de la sociedad musulmana, impulsada por la hegemonía de las normas de derecho civil y el general desinterés del poder en el mantenimiento de un eventual orden abstracto primitivo. Es indiferente que la ciudad fuera una planificación regular de origen romano o helenístico, una

12 La estrechez y la tortuosidad a que llegaron las calles andalusíes se explican porque el Islām medieval no utilizó la rueda ni el carro, que en las ciudades occidentales impusieron ciertos límites al trazado viario. La jurisprudencia mālikī consideró idónea para las calles públicas una anchura de 7 codos, que permitía cruzarse a dos acémilas cargadas con fardos a ambos lados (JIMÉNEZ y NAVARRO 200I: 90).

I3 Donde el suelo pertenecía al señor y sus ocupantes eran meros usufructuarios. Muchos documentos de los siglos XII y XIII consideraban inalterables las parcelaciones, rústicas o urbanas, ordenadas en la población de nuevas villas; así, en el nombramiento de quiñoneros para Mosqueruela (Teruel), de 1265, se advirtió que la parcelación que trazaran sería «firme y estable a perpetuidad». 
formación ortogonal creada ex novo por los musulmanes, un campamento militar estabilizado o un asentamiento no planeado; tras unas pocas generaciones, cualquier ciudad llegaba a un estado laberíntico muy semejante ${ }^{14}$.

Con el paso del tiempo, las trazas malladas abstractas las formaciones planeadas se transformaron en estructuras orgánicas arborescentes, caracterizadas por la precisa jerarquía del viario en calles públicas mayores y secundarias, y adarves de importancia decreciente; por la restricción de su funcionalidad a quienes estrictamente necesitaban utilizarlo, y por una mínima flexibilidad de uso ${ }^{15}$. Las autoridades no concebían el espacio urbano como una unidad homogénea, sino como un sistema donde el interés colectivo se ajustaba a un gradiente de intensidad según el número de usuarios potenciales.

Hay que advertir que, hasta los siglos $X u$ $X \mathrm{I}$, las ciudades no evolucionaron de una manera muy diferente en las regiones islámicas y feudales, proveniendo en buena parte nuestra idea de dos urbanismos radicalmente diferentes de la comparación de realidades diacrónicas. Sólo a partir de los siglos XII y XIII, cuando se traduzcan del árabe al latín los tratados matemáticos musulmanes, junto con las obras de Euclides o Ptolomeo, renazca la ciudad occidental y los estados nacionales emergentes se muestren en condiciones de aplicar técnicas de planeamiento más refinadas y se interesen por desarrollar un simbolismo urbano de raíz clásica, el urbanismo occidental acometerá realizaciones equiparables a las fundaciones áulicas y castrales que los musulmanes habían realizado desde el siglo VIII.
Conocemos en el territorio del Aragón actual ejemplos de planeamiento urbano musulmán de particular relevancia, a los que nos referiremos a continuación.

\section{Barbastro}

Barbaštur, la actual Barbastro, es una fundación de comienzos del siglo IX cuya planta rectangular centrada en una cruz de calles sugiere un origen castrense; según una tradición verosímil, a la sombra del castillo de al-Midyar, luego alcazaba, se estableció un campamento militar para reforzar la defensa en la línea cabecera de la Marca Superior. El campamento debió de ocupar el recinto rectangular del Entremuro, de trazado regular y organizado a partir de dos calles centrales, relativamente rectas y perpendiculares entre sí, que se cruzan en el centro del recinto; en el cuartel sudeste estaba la mezquita aljama, en el solar que ahora ocupa la catedral. Por orden de 'Abd alRaḥmān III, en el 918 se fortificó con una muralla de piedra con torreones, superior a las de todas las demás ciudades de la Marca Superior, según al-Himyarī. Durante el siglo X, Barbaštur se elevó a la categoría de madina y llegó a convertirse en cabeza de la cora que llevó su nombre.

Estaríamos, así, ante un típico misr emparentado, aunque a escala muy reducida, con ciudades nacidas de establecimientos campamentales primitivos como Kūfa, Bașra (Iraq), Fusțāt (Egipto), Qayrawān (Túnez) o, con mayor aproximación morfológica y salvando la mucha distancia, cAqaba (Jordania).

\footnotetext{
14 Este proceso permite entender la aparente contradicción entre la distorsión del espacio de ciudades preislámicas planeadas como Zaragoza, y la fascinación de los cronistas musulmanes ante su trazado regular, microcósmico, y la anchura y rectitud de sus calles. Al-cUdvī ( I003-1085) la describió así en un pasaje de sus Fragmentos geográfico-históricos que guarda cierta semejanza con el comienzo del fuero de Jaca de 1077: «Saraqusta, en lengua latina Yayar Agust, deriva del nombre de César Augusto [Qaysar Awgustus], que es quien la fundó. Dicen que fue construida en forma de cruz, y le hicieron cuatro puertas; una de ellas, en el comienzo del solsticio de verano, queda frente al sol naciente, y la opuesta, que corresponde a Occidente, queda frente al sol poniente. En el comienzo del solsticio de invierno, el sol naciente queda frente a la puerta que corresponde a la quibla, y el poniente frente a la puerta opuesta [...] La ciudad de Zaragoza y la de Astorga son semejantes en cuanto al trazado, la construcción, la fábrica y la solidez. No hay ninguna otra ciudad que se les parezca, si bien Zaragoza tiene mayor extensión. Fue construida entre cinco ríos»».

I5 La malla de calles abiertas en ambos extremos permite variadas posibilidades de desplazamiento entre dos puntos, y hace de toda calle posible paso para ir a otra; la red ramificada terminada en callejones ciegos obliga siempre el mismo recorrido e impide que los adarves de acceso a las viviendas funcionen como calles de paso.
} 


\section{La Zaragoza taifal}

Por las mismas fechas en que al-cUḍrī escribió la descripción de Saraqusta que citábamos más arriba, el rey taifa Ahmad Abū Ŷa $a^{c} f a r$ ibn Sulaymān al-Muqtadir bi-llāh ( I 046- I08 I) construyó el recinto fortificado de la Aljafería, desde entonces sede de la corte, en cuyas inscripciones conmemoró la reconquista de Barbastro ( 1065 ) tras perderse un año antes frente a la primera cruzada convocada en Occidente. La Aljafería es un grato palacio real y un organizado centro de gobierno construido por el soberano lejos de la incomodidad y la inseguridad de la ciudad. Pero, más que eso, es un embrión de ciudad perfecta, que rememora en pequeña escala la Madinat al-Zahrā' de 'Abd al-Rahmān III (936), émula a su vez, al proclamarse el Califato de Córdoba, de Mahdiyya (Túnez), nueva capital fātimí (9|2), y a la postre de la tradición iniciada por los califas cabbāsíes de manifestar su poder mediante la fundación de una ciudad perfecta: el nuevo estado y la nueva dinastía requerían una nueva capital, aun de escala tan reducida como la Aljafería, un gesto que ampliaba la refundación de la madina por Mundir I - el primer rey de la taifa saraqusțí-, también simbólica, mediante el engrandecimiento de la aljama y la construcción del nuevo barrio de la puerta de Șinhāŷa.

La Aljafería evocó deliberada y anacrónicamente los palacios omeyas del Creciente Fértil occidental, construidos en el siglo VIII a imagen de los trazados castrenses romanos y de palacios de la Antigüedad tardía como el de Diocleciano en Split, y, en los casos excepcionales de Mšatta y Ujaydir, tal vez de prototipos sasánidas. La planta es un trapecio, casi un cuadrado, de 76 metros (N-S) por 88 (E-W) ${ }^{16}$, orientado hacia los puntos cardinales ${ }^{17}$. El muro, construido en tapial, fue reforzado por dieciséis torreones de planta ultrasemicircular y diámetro descendente en altura, construidos con sillares de alabastro. Además de los palacios omeyas, los cubos ultrasemicilíndricos -hasta el momento infrecuentes en la arquitectura militar andalusí- imitaban ostensiblemente los de la muralla romana de Zaragoza, también de alabastro, con respecto a la que la Aljafería quedaba en una posición exterior, pero próxima. Como en Mšatta, la planta del recinto se subdividió en tres bandas aproximadamente iguales orientadas de sur a norte; el salón del trono ocupó el tercio norte de la banda central, flanqueado por un pequeño oratorio octogonal al este y precedido por un patio situado en el centro del conjunto. Como en Mšatta, 'Ayn al-Garr - Ujaydir, las bandas laterales albergaron viviendas y dependencias de servicio de las que no quedan vestigios. También como Mšatta, la Aljafería sólo tiene una puerta, flanqueada por dos cubos, que se abre en el extremo norte del paño oriental, en lugar del centro del paño sur, como hubiera sido normal; con este desplazamiento se quiso encarar la entrada del conjunto hacia la madina, con la que estaba unida a través de un camino paralelo al Ebro que llegaba a la puerta de Toledo, donde estaba la Sudda, y seguía hasta la mezquita congregacional.

Inseguro en el poder como otros reyes taifas, al-Muqtadir, segundo rey de la dinastía hūdí que en el 1038 había desplazado por la fuerza a los tuŷīíes, que, a su vez, se habían independizado del Califato de Córdoba tan sólo 47 años antes de la conquista de Barbastro, incluyó en la Aljafería alusiones explícitas a la arquitectura califal cordobesa -sobre todo en el salón del trono-, a la antigüedad omeya -origen oriental del Islām- y al urbanismo imperial romano -origen de la ciudad de Zaragoza. En estos intentos retóricos por expresar una legitimidad dinástica problemática, al-Muqtadir se aseme-

16 Unos $6.700 \mathrm{~m}^{2}$ de superficie, aproximadamente lo mismo que Qașr al-Hayr aš-Sarqī (un cuadrado de 80 metros de lado) y algo por encima de la media de los palacios omeyas de Siria, Jordania y Palestina, que GRABAR (1973: I62), tras haber estudiado una veintena de ellos, establece en $70 \times 70$ metros.

17 El muro oriental, que mira a la ciudad, está casi perfectamente orientado de sur a norte; el eje norte-sur del palacio gira algo menos de $9^{\circ}$ en el sentido contrario a las agujas del reloj, supongo que para acomodar la orientación del mihrab del oratorio anejo al salón del trono, girado $45^{\circ}$ con respecto al eje del palacio. 
jó al segundo rey aragonés, su contemporáneo Sancho Ramírez, que recurrió a la arquitectura románica y al urbanismo romanista de Jaca con el mismo objeto.

La Aljafería no fue el único proyecto de escala más o menos urbana realizado en la Saraqusța taifal. En las excavaciones realizadas en los años 2001 y 2002 para la construcción de un estacionamiento bajo el paseo de la Independencia y del nuevo Archivo de la Corona de Aragón en las inmediaciones del edificio Pignatelli, emergieron sendas agrupaciones de viviendas tradicionales organizadas en torno a patios, correspondientes a dos barrios residenciales levantados, al menos en el primer caso, a partir de planes geométricos de trama viaria ortogonal.

Los dos barrios se formaron en el siglo $\mathrm{XI}^{18}$, y su origen ha de vincularse al particular momento cultural, económico y político que vivió la ciudad en el período taifal. La afluencia de inmigrantes y la construcción de la Aljafería serían posibles causas de su urbanización, a uno y otro lado del arrabal de Azoque, que desde finales del siglo IX o comienzos del X se habría ido formando en el entorno de la dicha calle; a pesar de esta interrupción, en ambos casos se mantuvo una trama ortogonal ${ }^{19}$. A diferencia de los arrabales especializados formados antes en las salidas de la madina para alojar actividades cuyo emplazamiento tendía a situarse extramuros independientemente de la disponibilidad de espacio dentro de la muralla, los de la puerta de Șinhāŷa y del Campo del Toro son tejidos residenciales convencionales, si acaso con estructuras comerciales vinculadas al mercado de la puerta de Șinhāŷa y al transitado camino que lo unía con las Santas Masas. Hay que suponer que la formación de estos arrabales respondió a una acuciante necesidad de nuevo suelo urbano, por haber quedado pequeña la madina para una población en pleno crecimiento. El desarrollo de la ciudad en el siglo $\mathrm{Xl}$, verdadero canto del cisne de Saraqusța, se debió, paradójicamente, al derrumbe de la sociedad andalusí, expresado en la desaparición del Califato y el consiguiente clima de inseguridad en extensas zonas de al-Andalus ${ }^{20}$, y al progreso de la feudalización en Occidente ${ }^{2 !}$. Este crecimiento demográfico y económico vino unido a unas nuevas estructuras políticas empeñadas en una retórica del poder que compensaba una situación objetiva de inestabilidad y se beneficiaba del drenaje de la tributación territorial, a la sazón muy superior a lo admitido por el Corán, hacia la nueva capital 22.

I 8 Probablemente, en tiempo del primer rey taifa, Mundir I (I0 | 8- I022), el arrabal aparecido en el paseo de la Independencia, al que en adelante llamaremos de la puerta de Sinhāŷa, y durante el reinado de al-Muqtadir el del Archivo de la Corona de Aragón, al que llameremos arrabal del Campo del Toro.

19 En el caso de Independencia, con un trazado ortogonal de las calles; en el de Campo del Toro, sólo podemos referirnos a los muros de las casas.

20 Si entre los siglos VIII y X la Marca Superior y Saraqusta habían mantenido unas relaciones mínimas con el resto de al-Andalus, que contrastaban con una fuerte relación cultural con Oriente, desde el inicio del siglo XI afluyeron numerosos inmigrados de Córdoba y del sur de al-Andalus, que huían de las persecuciones de intelectuales por Almanzor y de la fïtnā. Por supuesto, también acudirían a la ciudad habitantes de su entorno rural, en busca de seguridad frente a las cada vez más frecuentes correrías aragonesas o atraídos por el incremento de la actividad terciaria

2I En buena parte, el fuerte crecimiento demográfico de Saraqusta a partir del año mil, confirmado por las ordenaciones residenciales recientemente descubiertas, se debió al proceso de feudalización que al mismo tiempo se estaba verificando en las sociedades europeas, proceso imparable y expansivo que acabó a medio plazo con la formación social andalusí. Gracias al desarrollo de las estructuras feudales al norte de la Marca Superior y al consiguiente incremento del excedente, se multiplicó el tráfico comercial entre Occidente y al-Andalus, motivando el crecimiento de Saraqusța, «puerta de todas las rutas» en palabras de al-cUdrī. Así, el desarrollo urbanístico del período taifal mantuvo una estrecha relación con las fundaciones burguesas a fuero de jaca con que los reyes ramirenses jalonaron las rutas de comunicación de Francia con la península, a través de Aragón y Navarra. Por otro lado, una parte apreciable del oro que la taifa daba regularmente al rey de Aragón en concepto de parias -aunque la del león era gasto bélico- se reinvertía en la adquisición en Saraqusta de productos manufacturados, sobre todo suntuarios, y de materias primas procedentes del Sur. Durante el siglo XI y el comienzo del XII, el incremento del poder adquisitivo en Aragón no indujo la creación de una clase burguesa ni la proliferación de actividades artesanales y mercantiles en su territorio, sino que redundó, ante todo, en beneficio de Saraqusta.

22 Como expuso IBN JALDUN en un importante pasaje del Muqaddimah (IV, I7), el florecimiento de la ciudad capital en la formación social islámica medieval -calificada como tributaria o mercantil-tributaria- se debió a su absorción de las rentas que el soberano recaudaba y redistribuía entre sus allegados, obligados como él, para mantener su prestigio, a un gasto suntuario que encauzaba la riqueza hacia la artesanía, el comercio y la cultura. 
Desconocemos la extensión de los dos barrios, sin duda superior a la mostrada por las respectivas excavaciones. El arrabal de la puerta de Șinhāŷa pudo limitar al oeste con el arrabal de Azoque, al norte con las construcciones preexistentes en torno al mercado de la puerta de Sinhâŷa -entre las que hubo una alhóndiga-, y al sur con la necrópolis y los baños construidos junto a la iglesia paleocristiana de las Santas Masas. Este arrabal no surgiría como una ampliación del de Azoque, sino como una formación urbana estructurada a los lados de la vía que unía la puerta de Șinhāŷa con las Santas Masas ${ }^{23}$. El arrabal del Campo del Toro pudo haber llegado por el este hasta el arrabal de Azoque o a sus proximidades, $y$ al norte hasta un camino que llevaba de la parte meridional de la madina a la Aljafería ${ }^{24}$ y desde donde debieron de producirse los accesos principales al barrio. Este arrabal acogió a familias de nivel económico superior al de Independencia, a juzgar por el mayor desahogo de las casas y sus mejores condiciones constructivas. Su proximidad a la Aljafería sugiere una vinculación de sus ocupantes, cortesanos o funcionarios, con el palacio reconstruido por al-Muqtadir, de forma parecida, aunque a escala más modesta, a la implantación califal planificada junto al camino que unía Córdoba con Madīnat al-Zahrā'.

El gran interés de los hallazgos radica en su correspondencia con tramas ordenadas sobre suelos no urbanizados antes del siglo Xl, y que, en la parte excavada, no volvieron a soportar estructuras residenciales después del siglo XII o los primeros años del XIII, de modo que un corto período de ocupación preservó las características geométricas de la ordenación de la distorsión producida por el derecho civil islámico o por la feudalización de la ciudad. La mayoría de las casas podrían haber quedado ya abandonadas en el año siguiente a la conquista como consecuencia de la emigración forzada por la capitulación de la ciudad, vaciándose totalmente ambas áreas en un plazo corto; al no haberse construido ningún barrio ni apenas edificación desde I | | 8 hasta el final de la Edad Media -salvo la fallida iglesia románica de tres naves cuya cimentación apareció en las excavaciones de Independencia ${ }^{25}$, estos suelos debieron de permanecer abandonados primero y ocupados después por huertas y eras, y, ya en la baja Edad Media, por unos pocos grandes recintos conventuales con abundantes espacios libres y huertas propias. De manera similar, sobre el solar del ensanche de Madre Rafols pervivieron por siglos las eras del Campo del Toro.

Ante los restos del arrabal de la puerta de Șinhâya no puede cabernos duda de que respondió a un planeamiento previo ${ }^{26}$, de naturaleza muy probablemente pública ${ }^{27}$. Bajo el Paseo, afloraron siete manzanas (dos prácticamente completas) y cinco calles, dos de dirección norte-sur (la que unía la puerta de Șin-

23 Junto con Santa María la Mayor (el Pilar), era el principal templo mozárabe de Zaragoza.

24 Paralelo al que, al norte, discurría junto a uno de los tres grandes cementerios de la ciudad y tenía el carácter de vía ceremonial.

25 Cuya implantación, ajustada a los límites este y oeste de las manzanas y con una forzada cabecera anticanónicamente orientada a norte (como la Seo), sugiere un intento de mantener parte de la trama viaria taifal, pero también la completa despoblación del arrabal, dos de cuyas manzanas hubieran sido ocupadas por la iglesia.

26 Aunque podamos intuirlo, los datos que tenemos no nos permiten afirmar que el arrabal del Campo del Toro respondiera a una planificación isodómica, como el de la puerta de Șinhāŷa.

27 Tienen razón NAVARRO y JIMÉNEZ (2003) al recelar de la tendencia reciente a ver por todas partes planes isodómicos de iniciativa estatal. Pero este escepticismo no debería llevar a la negación sistemática del planeamiento ortogonal ni de la capacidad interventora del estado, particularmente en las capitales estatales (las ciudades palatinas cabbāsíes, la Córdoba califal, la Zaragoza taifal...) La regularidad de la parcelación propiamente urbana del arrabal excavado en Independencia no se explica por la sola pervivencia de las trazas de la parcelación rústica anterior; por otro lado, las características de la red viaria, la apretada regularidad de los lotes y la ubicación de los accesos nos llevan a pensar en una intervención directa o indirecta del estado antes que en la autogestión de grupos preconstituidos. La saturación de las manzanas excavadas mediante parcelas modulares-muy evidente en la meridional, de planta cuadrada-, no permite pensar en la progresiva colmatación de un lote de colonización inicialmente rico en espacios libres, sino en la realización de un plan de alta densidad: 12 viviendas en una manzana de unos $1.165 \mathrm{~m}^{2}$ implican una densidad sobre manzana neta de 103 viv/ha; téngase en cuenta que Torres Balbás estimó una densidad media sobre suelo urbano bruto de 58 viv/ha en tejidos saturados. 
hâŷa con las Santas Masas y una paralela al oeste) y tres transversales, formando una trama ortogonal. Aunque lo limitado de los restos aflorados no permite demasiadas generalizaciones, puede pensarse en manzanas más o menos cuadradas de 32 a 37 metros de lado (o rectangulares de lados submúltiplos), subdivididas en parcelas rectangulares y separadas por calles de 2 a 4'50 metros de anchura, según su importancia 28.

Resulta evidente que las manzanas de este arrabal mantuvieron una relación modular con las parcelas, en origen iguales entre sí; con el tiempo, se producirían particiones y agrupaciones de solares que deformaron, aunque de modo poco sensible, el parcelario original, sin llegar a afectar apenas a las calles. La modulación parcelaria es más clara en la manzana meridional, de unos 33 metros en dirección este-oeste por 36 en la norte-sur, donde la parcela fundacional debió de tener unos 8 metros (este-oeste) por II (norte-sur). En su interior penetra un adarve de I'80 a 2 metros de anchura, con acceso desde el lado oeste; la configuración de la manzana y de la trama viaria sugiere que este adarve, que daba paso a las parcelas interiores, es contemporáneo de la urbanización ${ }^{29}$. El perímetro de la manzana está ocupado por diez parcelas (cuatro módulos de 8 metros en los lados norte y sur; tres módulos de II metros, más la anchura del adarve, en los lados este y oeste) y dos más en el interior ${ }^{30}$. Es importante subrayar, porque evidencia la gran mutación experimentada por el urbanismo musulmán desde sus orígenes campamental-gentilicios, que, exceptuado un mínimo de casas con acceso por el adarve, la mayoría de los zaguanes tenían entrada desde las calles pasantes exteriores, probablemente al-musliminn.

La otra manzana excavada casi en su integridad, al norte de la anterior, tiene una dimensión equivalente en dirección este-oeste, pero sensiblemente menor en la perpendicular (de 25 a 28 metros), lo que permite imaginar que en origen se subdividió en sólo dos filas de parcelas con acceso desde las calles que la limitaban por el norte y por el sur, si bien el destrozo causado por la cimentación de los ábsides dificulta una interpretación clara. Parece que en fecha posterior se formó un adarve privado para dar acceso desde la calle pasante septentrional a una pequeña parcela enclavada en la zona central de la manzana.

Es posible que con el plan del arrabal de la puerta de Șinhāŷa Mundir I quisiera simbolizar su capacidad ordenadora y emparentarla con el modelo ideal romano y, mutatis mutandis, con la refundación de Mūsà ibn Nușayr en el 7| 4. Los hallazgos de Independencia refuerzan el paralelo que hemos propuesto en otros lugares entre la intención románica de Sancho Ramírez y la de los reyes taifas, permitiéndonos las más atractivas hipótesis su cotejo con el plano de Jaca (fuero de 1077, con constitución simultánea de la diócesis -la primera en territorio cristianoaragonés- e inicio de las obras de la catedral). Advertido que la forma cuadrada de las manzanas de Jaca resulta extraña a la planificación occidental del siglo Xl, podemos preguntarnos por la posible relación entre ellas y la ordenación urbana que algún tiempo antes, e incluso simultáneamente, se había realizado en Zaragoza. Del mismo modo que los nueve torreones semicilíndricos del recinto

\footnotetext{
28 Decreciente conforme se alejan de la madina. El tramo excavado del camino de las Santas Masas alcanzaba una anchura de 4'50 metros en su extremo norte, unos 3'40 metros a la altura de las manzanas centrales y 2'80 metros entre las meridionales. De las calles perpendiculares a esta vía, la de mayor sección era la más próxima a la madina, que oscilaba entre los 2'90 y los 3’40 metros; la anchura de la primera paralela estaba comprendida entre 2'l0 y 2'70 metros, y la segunda debió de ser similar a ésta o todavía más estrecha.

29 Cuando afirmo que el adarve debió de nacer con el barrio no quiero decir que necesariamente se planeara, ya que es presumible que la decisión de truncar algunas calles pasantes, y también en parte su estrechamiento, se produjera en el momento en que los primeros ocupantes del barrio recién replanteado acometían la construcción de sus casas.

30 Con el tiempo, las doce parcelas originales se transformaron en quince, con partición en dos mitades iguales de tres parcelas (dos de ellas de esquina -SE y SW- y otra en el lado norte) y absorción de la mitad de otra parcela (la de la esquina NE) por la colindante, reduciéndose en consecuencia el resto de parcela a la mitad.
} 
exterior del castillo de Loarre, fortaleza áulica construida frente a Huesca por Pedro I ( 1094 I 104), parecen rememorar los cubos de la muralla de Zaragoza y de la Aljafería, Sancho Ramírez bien pudo haberse inspirado en el desarrollo de la Saraqusța taifal, la Cæsaraugusta romana, en la planificación de su nueva capital.

\section{LA CIUDAD CRISTIANA: URBANIS- MO ROMÁNICO}

\section{La urbanización medieval}

La ciudad cristiana medieval presentó rasgos de regularidad geométrica cuando se verificaron las condiciones objetivas que más arriba enumeramos como necesarias para ello, lo que a partir del siglo XI ocurrió con frecuencia por efecto de un modo de producción, el feudalismo, que dio lugar a unas novedosas estructuras de propiedad y de poder.

La Iglesia, los reyes y los señores afianzaron en los siglos XI a XIII instituciones de gobierno fuertes, estables $y$ coherentes, entre las que descollaba un aparato estatal y paraestatal jerarquizado presente en todo momento y lugar para recaudar impuestos, dictar justicia, mantener el orden económico y social y, en definitiva, penetrar toda la sociedad con la voluntad del poder; acompañando este proceso, una estructura eclesiástica jerarquizada, expresada en las parroquias y los conventos, se desplegó sobre la red urbana para enraizar el control ideológico de la sociedad. En la transición de la sociedad segmentaria al estado, tuvo un papel fundamental la reestructuración de la ocupación territorial, que, mediante la fundación de nuevas villas y barrios, reordenó la distribución de la población en el territorio, atrajo nuevos pobladores y facilitó la mejor explotación de los recursos naturales y de las oportunidades comerciales, así como el sometimiento de la población a las renovadas estructuras de poder.

La primera consecuencia urbanística de estas estructuras fueron las villas de fundación que poblaron Europa desde el siglo XI, cuando reyes, monasterios y grandes señores territoriales se interesaron por concentrar la población antes dispersa sobre el territorio para hacer eficaz su señorío y optimizar los rendimientos de la explotación agraria ${ }^{31}$. Como escribió DUBY (1962), la intensa repoblación que entre los siglos XI y XIII se verificó en toda Europa, y no sólo en la España de la reconquista, debió mucho a la voluntad de los señores de hacer más beneficiosa la explotación de los derechos inherentes a la autoridad y a la tenencia de amplias extensiones de tierra, hasta entonces poco cultivadas ${ }^{32}$.

En el seno de esta profunda reestructuración de las formas de explotación y ocupación del territorio, la proliferación de las nuevas fundaciones y el crecimiento de las ciudades entre

3I La función de las villas de fundación como nodos de penetración de las nuevas redes de poder centralizado explica el papel que en su implantación tuvo la geometría, tanto en la escala urbana como en la territorial. El territorio debía someterse mediante villas uniformemente espaciadas y sujetas a una jerarquía. En el orden interno, la geometría permitía controlar el asentamiento de la población, repetir una y otra vez eficaces modelos urbanos y, más adelante, escenificar la impronta del poder mediante recursos urbanísticos que superaban las exigencias impuestas a las aldeas campesinas formadas por impulso de sus propios habitantes. El contenido simbólico del poder implícito en las geometrías rígidas se enfatizó con la consolidación de los nuevos estados centralizados, desde las últimas décadas del siglo XII, para producir ejemplares muy acabados a lo largo del XIII.

32 La asociación de la urbanización feudal a la mejora de las técnicas de explotación y al aumento de los excedentes no debe hacer pensar en un enriquecimiento general de la sociedad. Antes bien, la formación de villas de colonización y de ensanches urbanos vinieron posibilitados por potentes migraciones provocadas por el empobrecimiento de los campesinos, la pérdida de sus pequeñas propiedades y la creciente presión fiscal. Las colonizaciones de los siglos XII y XIII no evitaron, sino que expandieron por nuevos territorios el fraccionamiento de la propiedad rústica que reducía al máximo las posibilidades de inversión para aumentar el rendimiento de la tierra y del trabajo, y ponía a cada familia campesina en una situación límite que le impedía acumular reservas para hacer frente a cualquier eventualidad. Las poblaciones europeas de tamaño grande y medio experimentaron engrosamientos demográficos no acompañados de aumentos del trabajo y la riqueza, y, en definitiva, se generalizaron procesos de superpoblación y empobrecimiento urbanos, con deterioro de las condiciones de vida, cuyas consecuencias se manifestaron en las terribles epidemias del siglo XIV; los nuevos suburbios estuvieron mayoritariamente habitados por una población marginal y empobrecida: entre los siglos XIV y XVII se dibujó una segregación social del espacio urbano que prefiguró la característica más relevante de la futura ciudad capitalista (GEREMEK 1986: 66 y 80-8I). 
los siglos XI y XV no puede aislarse del abandono y la decadencia de numerosas poblaciones rurales.

\section{Las villas de fundación}

Hemos adelantado que la instauración de las estructuras feudales no se limitó a la constitución de grandes dominios señoriales; desde comienzos del siglo XI, la alteración de las formas de explotación características de la alta Edad Media requirió el establecimiento de castillos en lugares estratégicos del territorio que, a cambio de apoyo militar, los reyes dieron en régimen de honor a los grandes personajes de su entorno, que las añadieron de hecho a sus patrimonios familiares. Se indujo así un primer proceso de reestructuración demográfica, con tendencia a la concentración de los hogares campesinos en torno a las fortificaciones, paralela al sometimiento de los pequeños propietarios alodiales a formas de punción del excedente propiamente feudales, auspiciadas por los tenentes y las huestes de guerreros a su servicio. La desarticulación del espacio rural altomedieval, más o menos homogéneamente poblado por pequeñas aldeas y caseríos dispersos, dejó paso a un marco propicio a las relaciones feudales: la población se estructuró y se encuadró en la nueva división dominical y jurisdiccional del territorio, con la poderosa ayuda de la renovada estructura eclesiástica de parroquias y diócesis, más las divisiones intermedias de los arciprestazgos; se establecieron nuevas divisiones administrativas -tenencias, merindades, alfoces...- en correspondencia con las eclesiásticas; se articularon eficaces sistemas de succión de la renta feudal y se forjó una cadena de dependencias personales.

Este proceso de concentración de la población rural fue paralelo a la jerarquización de los núcleos de población. Por una parte, se con- solidaron las civitates donde estaban establecidos los obispos; por otra, se formaron circunscripciones señoriales en torno a los castillos (no necesariamente sobre propiedades del señor), cuyos campesinos fueron abandonando el hábitat disperso para concentrarse alrededor de éstos; finalmente, se creó ex novo una red de burgos intermedios dedicados al comercio y la artesanía, y vinculados a los principales ejes de comunicación territorial, con el Camino de Santiago ${ }^{33}$ como ejemplo más destacado.

Desde el último cuarto del siglo $\mathrm{Xl}$, el proceso de repoblación y reestructuración demográica, económica y jurídico-política del territorio se atuvo a una planificación de alcance más general y a instrumentos jurídicos más elaborados, como las cartas de población y los fueros, cuyo contenido era diferente según el tipo de habitantes y funciones que los dueños de la tierra querían implantar en la población naciente, ampliada o refundada. Los procesos de repoblación no sólo se beneficiaron del perfeccionamiento de las herramientas jurídicas, sino también del instrumental urbanístico, que a finales del siglo XI vio renacer los trazados regulares y sistematizados. Estos trazados fueron posibles gracias a que las fundaciones se producían en suelos pertenecientes a un señor -el rey, un señor territorial, una institución eclesiástica, un señorío urbano, una comunidad de villa y tierra...- al que correspondía ordenarla en todos sus aspectos antes de entregar las parcelas a los pobladores en régimen de tenen$\mathrm{cia}^{34}$ para que se instalaran y ejercieran sus actividades -mercantiles, artesanales, agropecuarias o bélicas- con la consiguiente extracción de un beneficio por parte del fundador, tanto en forma de renta agraria, diezmos, tributos, multas, derechos de mercado, peajes u otras banalidades, como por la misma mejora en la comercialización de la producción, o el incremento en la seguridad del territorio.

\footnotetext{
33 En el siglo Xl, el único eje territorial que recorría toda la España cristiana y la unía con el resto de Europa.

34 Parcelas urbanas solamente, cuando se trata de pobladores burgueses (fuero de Jaca) o parcelas urbanas y parcelas rústicas (fueros militares y de extremadura), a veces con concesión adicional de todo aquel suelo yermo que se pusiera y mantuviera en explotación.
} 
El rey o el señor interesado en la fundación de una villa en terrenos de su pertenencia promulgaba un fuero o una carta puebla que contenía privilegios para atraer población, diseñados a la medida del tipo de colonos pretendido: libertad de circular, reducciones fiscales y exenciones militares para atraer burgueses; obligación de tener siempre un hombre armado en casa, participación obligatoria en cabalgadas y huestes con derecho a parte del botín, u otorgamiento de parcelas mayores para quienes tuvieran caballo para atraer guerreros; derecho de escaliar (apropiación de la tierra yerma que cada cual cultive) para atraer agricultores dispuestos a poner en cultivo extensos términos incultos...

Las fundaciones medievales requerían una planificación parcelaria que, por medio de la geometría, impusiera un orden en la partición del suelo y posibilitara su incorporación al proceso productivo y fiscal; la parcela destinada a albergar la casa de una familia nuclear -padre, madre e hijos solteros- era a la vez unidad fiscal y unidad compositiva de la nueva villa. En las nuevas villas, el plano parcelario era el punto de arranque de la vida urbana, el elemento originario, generativo en todos los órdenes. Más tarde, como instrumento estructurador de la distribución de rentas urbanas y rústicas en el término, el parcelario seguiría siendo un elemento económico y social fundamental.

Además de la parcelación regular, en las ciudades y barrios de nueva planta se trazaron callejeros ordenados, que buscaban la máxima eficacia funcional, la delimitación de manzanas adecuadas para la parcelación pretendida, y, a partir de cierto momento, un determinado efecto estético, expresado en el ideal tardomedieval de la ciudad como forma bella.

CANIGGIA (1973: 31) propuso una serie de constantes en la formación de cualquier agregado urbano espontáneo, evidentes en las poblaciones medievales, que podemos hacer extensivas a los núcleos planificados más simples de los siglos XI y XII, de tipo lineal:

a) Todo asentamiento se produce sobre un recorrido, previo, que lo genera: las parce- las residenciales se van sucediendo a los lados de un camino territorial existente.

b) En el tejido parcelario-edificatorio que se apoya en el recorrido aparecen siempre unas características precisas:

- Modulación de la anchura del frente de fachada. Esa anchura correspondía a la longitud usual de una viga de madera o de ésta más el ancho de la escalera longitudinal (4'50-6 metros); si las casas se edificaban con medianeras comunes, como era frecuente en el Medievo, esta longitud de fachada era igual a la anchura de la parcela. También era común que entre cada casa y la contigua se dejara un callizo, herencia del ambitus romano, corredor de cinco pies que mediaba entre parcelas contiguas para evitar riesgos de propagación de incendios y favorecer el desagüe; esta solución suponía una mayor autonomía individual de los pobladores y una menor presencia del sentido de lo colectivo.

- Ortogonalidad de las parcelas con respecto al eje de la calle que les da acceso.

- Homogeneidad de las profundidades de las parcelas en la banda edificada, que comprende tanto los edificios como los espacios libres anejos, utilizados como corral y patio de luces. Incluyendo la profundidad de la casa y la de la zona, generalmente trasera, sin edificar, las parcelas de este período solían tener profundidades de 15 a 25 metros.

Todas estas características derivaban del uso codificado de un tipo residencial, la casa estrecha y profunda con dos fachadas en los lados cortos.

Si la población crecía, el camino primigenio podía completarse con nuevos recorridos paralelos. En este caso, resultaban manzanas longitudinales formadas por dobles filas de parcelas estrechas y profundas adosadas por sus traseras y con sus frentes recayentes a calles rectas paralelas de donde obtenían acceso; de éstas, una -el camino matriz- ostentaba el nivel jerárquico superior. 
Podían aparecer también trazados en espina de pez, que implicaban una complejidad mayor y preservaban mejor la homogeneidad de todas las calles de acceso, ya que, a diferencia del modelo anterior, se diferenciaban dos tipos de calles esencialmente distintos:

- la calle dorsal, coincidente con el recorrido matriz, sólo servía para la circulación general, dando acceso a las calles costales pero no a viviendas;

- las calles costales, que partían de la dorsal y a cuyos lados se alineaban, perpendicularmente, las parcelas, con acceso desde ellas; la circulación de estas calles estaba más restringida, ya que se limitaba, en general, a la que iba y venía del recorrido matriz a sus parcelas.

Además de la jerarquía viaria que introducía (con ventajas en cuanto a la exclusión del tráfico de paso de las calles con acceso a viviendas) y, con ella, la mayor homogeneidad funcional del parcelario (ya que todas las parcelas mantienían una relación mediada con el camino matriz), los trazados en espina de pez suponían una distinta orientación de las parcelas con relación al camino matriz que los trazados de calles paralelas al camino: en aquél caso, los frentes de las parcelas eran perpendiculares al camino, $y$, en el segundo, paralelos. Por eso, era corriente que los trazados de una sola calle o de calles paralelas a la matriz aparecieran cuando éste seguía una dirección de norte a sur, por lo que las fachadas daban a este y oeste; cuando el camino matriz tendía a una dirección de este a oeste, los esquemas en espina de pez permitían evitar fachadas orientadas a norte ${ }^{35}$.

Estas calles secundarias añadidas al camino matriz formaban tejidos urbanos por alineación de parcelas con las mismas características a) y b) señaladas más arriba, pudiéndose añadir dos nuevas:

c) Aunque el recorrido matriz pudiera ser más o menos irregular, las nuevas calles tendían a ser rectas, especialmente en los trazados en espina de pez (en los de calles de acceso paralelas, podían mantener un cierto paralelismo con la matriz).

d) Las nuevas calles de acceso estaban separadas entre sí por distancias más o menos iguales, equivalentes al doble de la profundidad de la parcela (esto es, de 30 a 50 metros), de modo que cada calle daba acceso a casas por sus dos lados.

Entre los recorridos de implantación edificatoria, que daban acceso a las casas, quedaban recorridos de conexión, estrechas y escasas callejas perpendiculares que sólo permitían el tránsito entre calles primarias y la evacuación de aguas, sin dar acceso, por lo general, a ninguna parcela. Estas calles secundarias no estaban sujetas a los condicionantes circulatorios de las principales, que sí contenían accesos, por lo que, mientras éstas tendían a coincidir con las líneas de nivel del terreno, aquéllas podían absorber fuertes pendientes e incluso convertirse en escaleras en poblaciones en ladera.

\footnotetext{
35En razón del máximo aprovechamiento del suelo, en la ciudad planificada en llano las manzanas solían estar formadas por dobles hileras de parcelas unidas por sus fondos; esto suponía que si las fachadas alineadas con uno de los lados largos tenían una orientación dada, las del otro lado tenían la opuesta; de ahí que la solución más equitativa fuera producir hileras edificadas con fachadas a este y a oeste; una orientación perpendicular de las calles hubiera permitido fachadas a sur, pero también hubiera obligado a que la mitad de las casas orientaran su frente principal a norte.

Este dilema no se producía en los muchos pueblos, de formación comúnmente espontánea, asentados sobre una ladera orientada a sur. En este caso, las calles adaptaban su trazado a las curvas de nivel y su disposición era asimétrica, puesto que, para adaptarse mejor a la pendiente, las manzanas solían consistir en una alineación simple de parcelas, de forma que sólo a un lado de cada calle había accesos (o bien a un lado estaban los zaguanes y al otro las entradas a dependencias agrícolas). La fachada norte sólo tenía una o dos plantas, mientras que la fachada sur tenía por debajo más niveles para salvar el escalonamiento del terreno, alcanzando en total tres o cuatro plantas; normalmente, la inferior de todas se dedicaba a los animales, con entrada diferenciada desde la margen septentrional de las calles, y el zaguán se abría, en un nivel superior, en la fachada norte. Esta solución proporcionaba protección frente a los vientos del norte y óptimo asoleo de la fachada sur, y, al elevar el caserío en la ladera, facilitaba la defensa, alejaba las casas de las aguas de escorrentía y liberaba para el cultivo las mejores tierras del llano.
} 
La distancia entre las calles secundarias no estaba modulada con la rigidez con que se separaban las calles primarias, ya que el potencial de agregación transversal de las parcelas estaba limitado al doble de su profundidad, pero el potencial de agregación longitudinal era indefinido, pudiendo ser muy variable la longitud resultante de las manzanas, que no dependía ya del tipo edificatorio, sino de la distancia razonable entre conexiones de calles primarias y secundarias, de acuerdo con las necesidades de la circulación urbana y de la evacuación pluvial.

En los ejemplos más espontáneos, las calles secundarias cortaban a las primarias de manera independiente en cada manzana, con lo que la alineación en todo el conjunto se verificaba en las calles de acceso, pero no en las de conexión. En los ejemplos planificados, los ejes de las callejas de conexión que atravesaban manzanas paralelas tendían a coincidir, aproximando el trazado viario a una retícula desigual, con calles más frecuentes, más anchas y con accesos en una dirección, y calles más raras, estrechas y sin accesos en la perpendicular (como ocurre en el barrio de San Pablo de Zaragoza).

Conforme los trazados son más tardíos, la longitud de las manzanas, al principio muy larga, tiende a disminuir, reduciéndose al doble o el triple de la anchura, y, en los ejemplos más avanzados, ya del siglo XIII en adelante, a una dimensión igual a la anchura, produciendo manzanas cuadradas y calles equidistantes en las dos direcciones. Mientras no se desarrollen tipos residenciales más complejos para la resolución de las esquinas, estos trazados en dame- ro no serán más que una apariencia de cuadrícula: durante la Baja Edad Media, aun cuando las manzanas fueran cuadradas y las calles parecieran iguales en las dos direcciones, ni aquéllas daban fachada más que a dos lados, ni en éstas había accesos más que en una de las direcciones.

En las villas de los siglos XI y XII, a la homogeneidad del parcelario se añadió la inexistencia de algo comparable a un centro urbano, con exclusión de plazas y edificios privilegiados, que, aunque inmediatos, solían quedar fuera del caserío ${ }^{36}$. Antes del siglo XIV, las plazas del mercado eran más bien amplios yermos situados a la entrada a la villa, normalmente junto a la iglesia. Incluso muchas de las iglesias que hoy en día ocupan el centro del parcelario, como la parroquia de la Asunción de Canfranc, estuvieron inicialmente en un extremo, que en los núcleos itinerantes solía ser el de la entrada; en poblaciones con dos parroquias, era muy frecuente que se emplazara una en cada extremo, y en las más complejas, con tres o más parroquias, se mantenía la tendencia a emplazarlas junto a puertas de la cerca.

Con estos elementales principios, los nuevos burgos y villas se trazaron en los siglos $\mathrm{XI}$ y XII según criterios sólo dirigidos a lograr la homogeneidad del parcelario y una racionalidad elemental en el trazado de las calles; más que la regularidad en sí misma, se buscaron la igualdad y la repetición ${ }^{37}$. Lo prioritario en la ordenación no era el espacio urbano, sino la parcela, unidad tributaria a partir de la que se verificaba la extracción de rentas ${ }^{38}$.

36 Así ocurrió en Canfranc, Alcorisa, Villafranca del Campo, Santa Cilia de Jaca...

37 A propósito de las bastidas francesas del siglo XIII, LAVEDAN y HUGUENEY (1974: 73) escribieron que son raros los textos que se refieren a tracistas de ciudades; las pocas referencias conservadas aluden a parceladores (lotisséeur), individuos encargados de dividir el suelo en parcelas fáciles de valorar y de repartirlas entre los pobladores, fijando en su caso el canon que éstos debían pagar a cambio de ellas; «de ahí a diseñar el plano de una ciudad, hay distancia», concluyeron.

38 Salvo excepciones como Jaca, capital de un nuevo reino vasallo de Roma y sede de su única diócesis, sería un contrasentido buscar en las creaciones del urbanismo románico intenciones artísticas o representativas, puesto que la ideología dominante no atribuía la menor sustancia estética o moral a la ciudad en general y a los asentamientos burgueses en particular. Durante el primer feudalismo, la nobleza y los monjes habitaban castillos y monasterios situados en medio de sus dominios rurales, en pleno florecimiento productivo, y las poblaciones y barrios burgueses no pasaban de ser escenarios económicamente secundarios, poblados, a los ojos de las clases dirigentes, por parásitos improductivos, ajenos a los tres órdenes feudales, que no trabajaban la tierra con sus manos. Todo esto era tanto más cierto como que las zonas de mayor actividad repobladora, entre ellas Aragón y Castilla, solían ser también las de mayor implantación e influencia política de Cluny, cuyo rechazo a la ciudad era tan manifiesto como luego lo sería el del Císter. Si la ciudad era obra del demonio, de donde el verdadero interesado en salvar el alma debía huir para recluirse 
La regularidad de las villas de fundación, como casi todo lo inherente al trazado urbano en casi todas las ciudades, no se debía a un capricho estético: la ciudad no pertenece a la categoría de lo artístico. Detrás de todo trazado hay unas precisas intenciones políticas y económicas. De ahí que cuando el relieve del terreno u otras circunstancias lo recomendaron, el plano se deformó cuanto hizo falta para preservar la urbanización regular y la funcionalidad del viario, como veremos que ocurrió en Aínsa, Berdún o Cordes.

\section{El fuero de Jaca y la atracción de pobladores francos}

En el siglo XI, mientras Europa experimentaba un gran impulso económico, el naciente reino de Aragón, despoblado y con escasos recursos naturales, no reunía las condiciones estructurales necesarias para el florecimiento espontáneo del comercio; pero Sancho Ramírez y sus sucesores aprovecharon la condición fronteriza del territorio, etapa obligada en las vías que unían la Península con Francia, para fundar un conjunto de burgos de mercado que se acompañaron con los más remotos trazados regulares del urbanismo feudal aragonés.

Los reyes ramirenses fundaron nuevas villas en tierras de su patrimonio personal, obteniendo pingües beneficios en concepto de tasas e impuestos a cambio de los privilegios que les otorgaban. Pero el destino de estas fundaciones no se agotaba en ellas mismas; antes bien, su fin primordial era el impulso de la producción agraria en las tierras próximas sobre los niveles de subsistencia, propiciando la superproducción para el mercado y el consiguiente incremento de la renta de que se beneficiaban, además del propio rey, los monasterios cluniacenses y los señores laicos beneficiarios de concesiones territoriales en el entorno de las grandes rutas de comunicación, entre las que en ese momento -y no por mucho tiempo- el camino de Santiago ostentaba la supremacía ${ }^{39}$. El hecho de que el estudiado proceso de infeudación del territorio navarro-aragonés incluyera programas simultáneos de fundación de burgos de mercado ${ }^{40}$ y de sistematización en la concesión en honor de castillos con sus términos rurales -con la consiguiente tendencia a la concentración de la población campesina en villas a los pies de las torres ${ }^{41}$-, demuestra la estrecha complementariedad de los dos fenómenos de mejora de las técnicas de extracción señorial del excedente agrario y de incremento de ese excedente por la circulación mercantil, y corrobora la tesis, enunciada por Guy Bois, de la decisiva importancia del mercado en la formación del feudalismo: la organización de una eficaz estructura de castillos e iglesias para la punción sistemática del excedente campesino debe ir acompañada por un desarrollo mercantil que impulse la producción más allá de los niveles de subsistencia.

\footnotetext{
en un monasterio, los barrios burgueses entraban de lleno en la marginalidad. Los burgueses, amantes del vicio y del dinero, cantaban las excelencias del aire de la ciudad, que, como decía el adagio alemán, los hacía libres. Pero quienes no lo eran, y en particular los eclesiásticos, podían, con san Bernardo, comparar a París con Babilonia y afirmar que las ciudades habían sido sembradas por el diablo con las cenizas de Sodoma y Gomorra; no en vano, según Génesis (4, 17) la primera ciudad de la Tierra, Henok, había sido construida por Caín después de su expulsión del Paraíso. Los burgos fundados por los reyes y los señores del primer feudalismo para estimular la actividad comercial en sus dominios se nutrieron de pobladores jurídica y socialmente marginales, francos y judíos, a los que el fuero de Jaca también concedió un trato favorable; la actitud mental ante el proyecto de un nuevo burgo mercantil no debió distar mucho de la que pudiera haberse tenido ante la fundación de una puebla de moros o un barrio de judíos, si no de una mancebía. Para reyes y señores, los burgos eran una fuente de ingresos pero, desde luego, no la base de su prestigio.
}

39 Más sistemático y ambicioso todavía que la política de establecimiento de burgos del Camino de Santiago, pero análogo en sus objetivos, fue el amplio programa de fundación de villas de mercado acometido por los Caballeros Teutónicos en los territorios conquistados en Prusia Oriental, Polonia y Checoslovaquia a partir de 1230: un centenar de nuevas villas mercantiles, en general centradas en extensas plazas y separadas entre sí de 30 a 40 kilómetros, que superpusieron al territorio agrícola incorporado al Sacro Imperio una densa trama de mercados comarcales desde los que se impulsó la ampliación de la producción y se succionaron sus excedentes.

40 Fueran los socorridos burgos del Camino o poblaciones lejanas a él, incluso carentes de fuero de francos.

4 I Fenómenos, a la vez, superpuestos a la formación de grandes dominios, sobre todo monásticos, iniciada tiempo atrás y a la sazón en un momento culminante de concentración, y a la estructuración jerárquica de la red eclesiástica, acompañada con la imposición de diezmos y primicias. 
No hubo, pues, una contradicción entre el proceso de encastillamiento propiciado por la Corona, mediante el que se reestructuró el campo y se concentró la población de acuerdo con las estructuras feudales importadas de Francia, y la fundación de los burgos mercantiles con que, sin demasiado éxito ${ }^{42}$, se quiso impulsar la producción agraria, según el modelo que BOIS (1989: 106-107) estudió en Cluny, donde antes del año mil se había creado una villa de burgueses a la sombra de la abadía, con mercado semanal $y$, desde mediados del siglo $X \mathrm{I}$, ferias periódicas; esta villa eclipsó pronto a Mâcon e impulsó la actividad agraria en el dominio monástico. No puede pasarse por alto la influencia de Cluny sobre Sancho Ramírez de Aragón y Navarra y Alfonso VI de Castilla, ni el hecho de que muchas de las villas burguesas de fundación real se situaran cerca de los grandes dominios cluniacenses, principales beneficiarios de los nuevos mercados ${ }^{43}$.

El mecanismo para la fundación de las nuevas villas y de los burgos mercantiles -también artificiales- que se adosaron a otras ya existentes, fue la concesión de franquicias y privilegios a los pobladores, mediante un fuero o una carta de población. Dichos privilegios que- daban referidos a zonas urbanas acotadas -aquellos burgos y villas que habitaban los burgueses. El modelo jurídico que luego se extendió por todo el norte de la península y por el sur de Francia para la atracción de francos fue el fuero de Jaca, dado a esta ciudad en 1077 e integrado por un conjunto de privilegios que entonces no eran reconocidos en ninguna otra parte del mundo: libertad de circular, limitación de obligaciones militares, importantes exenciones fiscales ${ }^{44}$... En este documento aparece, por primera vez en la península, la palabra burgensis, nacida en la Europa central en el primer lustro del siglo XI.

Después de 1077, el fuero de Jaca se concedió a poblaciones aragonesas como como San Pedro de Ruesta (ca. 1079), Aínsa (I I 27), Asín ( I | 32), Berdún ( I | 38; fuero de Jaca en I | 58), Mianos ( 1 170), o a barrios como el burgo nuevo de Ayerbe (ca. I I 22), burgo nuevo de Alquézar ( I | 25), el vicus novus o burgo de San Esteban de Luesia ( I 25; fuero de Jaca en II54) - Santa María de Uncastillo ( 1 169); a las poblaciones navarras de Estella (1077), burgo viejo de Sangüesa (antes de 1094), burgo nuevo de Sangüesa (I I 22), Puente la Reina (I I 22), Monreal (I |49), Villava (I | 84), Tiebas (I 264), Torral-

42 Por causa de la rápida expansión territorial de Aragón, propiciada precisamente por el atractivo de la conquista para los ejércitos feudales ultrapirenaicos, y que implicó la rápida incorporación al reino de las relativamente grandes ciudades de la Marca Superior: Huesca (I096), Barbastro (I | 00), Ejea (I |05), Zaragoza (I | |8), Calatayud (I |20), Daroca (I I20)... Frente a ellas, los artificiosos mercados sin ciudad creados a fuero jaqués - exceptuada la propia Jaca, verdadera ciudad emplazada también sobre la vía de Zaragoza y Huesca a Francia- casi quedaron reducidos a la nada, y el mismo camino de Santiago, fronterizo y encajado en territorios montañosos, vio abortadas sus expectativas económicas.

43 LAPEÑA (1994: 307ss.) estudió las relaciones entre la ciudad de Jaca y el monasterio cluniacense de San Juan de la Peña, a sólo 20 kilómetros, propietario privilegiado de campos de cereal y, en menor medida, de viñedos en el entorno rural de Jaca y otras poblaciones del Camino. Para el monasterio pinatense, como para el cercano de benedictinas de Santa Cruz de la Serós, muy vinculado a San Juan, Jaca fue la ciudad de servicios y el mercado natural que le permitió dar fluida salida a su producción. San Juan de la Peña poseía, además, un importante patrimonio inmobiliario en la misma ciudad de Jaca, entre el que ya a comienzos del siglo XII figuraban no pocas tiendas. Desde Jaca a la frontera Navarra, el Camino atravesaba tierras, ocupadas por un gran número de pequeñas aldeas, que en buena parte eran propiedad de San Juan de la Peña, titular también de extensos dominios en Navarra: en Estella, Sancho Ramírez tuvo que pactar con el cenobio la fundación del burgo, cediéndole la décima parte de sus rentas y la propiedad de sus iglesias a cambio de desviar la ruta hacia suelo de realengo. También Ruesta, la tercera de las fundaciones de francos navarro-aragonesas, se enclavó en terrenos de realengo lindantes con los dominios de San Juan de la Peña.

44 Estas libertades no constituían un estatuto de plena franquicia, sino una serie de privilegios, generalmente en aumento con el tiempo, que reducían sensiblemente las obligaciones de los pobladores con el rey, su nuevo señor natural. Aun en los casos en que otorgó a la ingenuitas y a la libertas absolutas, el rey seguía siendo el único propietario de la tierra -y, en cuanto tal, mantenía unos importantes derechos-, y cuantos privilegios otorgaba no pasaban de ser concesiones puntuales debidas a su buen ánimo y espontánea voluntad. Rara vez se dieron estos privilegios excepcionales a una villa completa; se limitaron siempre a burgos cuya formación y precisa extensión estaba prevista por el rey, cuidando de que no afectaran a los núcleos a los que se adosaban o a otras fundaciones paralelas; cuando, como era habitual, el burgo se fundaba junto a una villa castrense dada en honor a un tenente (Alquézar, Luesia, Pamplona...), ésta seguía sometida a ordenamientos jurídicos consuetudinarios, en tanto que el burgo se regulaba por fuero de francos. 
ba (I264) O los barrios pamplonenses de San Cernín (I I 29), San Nicolás (antes de I 184 ) y la Navarrería ( I | 89); también se otorgó a San Sebastián (ca. I I 80) o Fuenterrabía (I 203), en Castilla, y Céntulo IV lo dio entre 1078 y 1088 a los pobladores de Olorón, en el Bearn, mayoritariamente llegados de Canfranc. Alfonso II escribirá en II 87 que «consta que de Castilla, Navarra y de otras regiones suelen venir a Jaca para aprender sus buenas costumbres y fueros y llevarlos a sus lugares».

El fuero perseguía crear y preservar un núcleo de población homogéneo, para albergar una clase burguesa en la que todos los pobladores cristianos fueran jurídicamente iguales entre sí y ante el rey, fuera cual fuera su anterior condición y ya se tratara de caballeros, labradores o burgueses, lo que era un importante logro para los dos últimos grupos. Entre los siglos XI y XIII, todas las redacciones del fuero de Jaca coincidían en excluir de la posibilidad de posesión de tierras a los nobles y los clérigos. Para evitar la entrada de la ciudad como propietarios de estos dos estamentos indeseables, en el fuero de Jaca de 1077 se prohibía vender o regalar inmuebles a la iglesia y a los infanzones, limitando estos intercambios a los que se pudieran producir entre burgueses, con lo que la condición original del núcleo no se distorsionaba; en algunos casos, esta limitación quedaba reforzada por un derecho de tanteo sobre cualquier transmisión, con el fin de comprobar su cumplimiento.
De este hecho procede una característica común a las villas pobladas a fuero de Jaca: la homogeneidad extrema de su parcelario, la falta de cualificación urbanística de partes del plano y la ausencia de jerarquía viaria. A cada poblador se le otorgaba gratuitamente una heredad urbana (partem, plaçam o plaztam), igual a todas las demás, lo que requería una ordenación urbanística previa por parte de los merinos del rey ${ }^{45}$. Quienes vinieran una vez poblado el burgo, deberían adquirir el suelo a título oneroso a los pobladores que quisieran venderlo.

Los pobladores no eran propietarios del suelo, sino que, permaneciendo éste siempre bajo el dominio del rey, lo utilizaban libremente en régimen de honor; en consecuencia, no podían vender ni comprar un suelo que no era suyo, y que el rey les había concedido libre de cargas y gratuitamente por el hecho de acudir a poblar el lugar; pero sí eran de su propiedad las construcciones que sobre estas parcelas edificaban, y, por ello, se les reconocía el derecho a enajenarlas y transmitirlas a sus descendientes indefinidamente, si bien con ciertas limitaciones consustanciales a los intereses que habían inspirado la fundación de esas poblaciones ${ }^{46}$. En su item primero, el fuero de Jaca establecía la obligación de cada poblador de edificar y cercar la parcela que le fuera asignada por sus propios medios.

\footnotetext{
45 De ahí que el trazado de un plano parcelario homogéneo -y, por tanto, de una urbanización tan regular como permitiera el relieve del suelo- fuera complemento indispensable del fuero.

46 En ocasiones, la prohibición de vender o regalar bienes inmuebles a nobles y clérigos quedaba reforzada por un derecho de tanteo por parte del rey sobre cualquier transmisión; en Luesia o en Aínsa, se utilizó una fórmula que se limitaba a garantizar la indefinida posesión de las donaciones recibidas por el poblador y todos sus descendientes; en el burgo nuevo de Alquézar, se añadía una autorización expresa para poder disponer a voluntad de la propiedad, guardando las limitaciones impuestas por el fuero; en otros casos, la fórmula empleada, análoga a la de las concesiones de alodios a los nobles, limitaba el derecho de transmisión a la propia descendencia, siendo necesaria la explícita aprobación del rey en caso de enajenación a otras personas (LACARRA I98I: I 19). Ésta era la más repetida e importante de todas las trabas que en estos burgos se imponía a sus habitantes en cuanto a la disposición de sus propiedades inmuebles, que se tenían libres e ingenuas -esto es, sin trabas para ser enajenadas ni obligación de pagar un censo por su posesión. La segunda limitación, común a todas las concesiones de honores por parte del rey, era que su tenencia se subordinaba al deber general de la fidelitas, cuyo quebranto implicaba la desposesión. Por otro lado, y para evitar la formación dentro de estas poblaciones de poderes fácticos que pudieran amenazar el equilibrio económico interno y la misma efectividad del poder real, se impedía la concentración de propiedades mediante la prohibición de vender inmuebles sin el permiso regio y procedimientos como la prescripción de año y día, que, además de expresar el peculiar carácter utilitario del derecho del poblador sobre su parcela, dificultaba la acumulación fundiaria. Por esta prescripción de año y día, recogida ya en el primer fuero de Jaca, un vecino accedía a la propiedad efectiva de una heredad cuando llevaba ese tiempo poseyéndola sin que hubiera reclamaciones; a partir de entonces, y no antes, podía venderla, ateniéndose a las limitaciones forales.
} 


\section{Las primeras ciudades regulares en Aragón}

Desde 1076, Sancho Ramírez puso el máximo empeño en garantizar la paz en el Camino de Santiago y en asentar una población libre que explotara sus posibilidades económicas. Su política y la que simultáneamente llevó a cabo en Castilla Alfonso VI, de la mano ambos de Cluny y la iglesia gregoriana, imprimieron un gran impulso al Camino Francés como ruta de peregrinación, de intercambio y de urbanización, hasta convertirlo en el eje vertebral del desarrollo cultural y económico de una Hispania cristiana que comenzaba a imponerse de una manera irrefrenable al Islām.

La revitalización del Camino implicó actuaciones de diverso tipo: se erigieron iglesias repletas de reliquias y convertidas en centros menores de culto ligados a la peregrinación jacobea, se mejoró la infraestructura viaria, se fundaron albergues y hospitales ${ }^{47}$, y se colonizó con nuevos burgos el territorio atravesado por la ruta, convertida en importante motor económico. Como los emperadores romanos y los adelantados españoles en América, los reyes ramirenses de Aragón y Pamplona impulsaron esa colonización mediante la fundación o la revitalización de poblaciones como Canfranc, Jaca, Estella, Ruesta, Sangüesa o Puente la Reina.

Canfranc (Campus Francus), que no recibió el fuero de Jaca pero gozó de privilegios similares y probablemente fue poblada con francos, ejemplifica los más antiguos procedimientos de planificación regular en la Edad Media europea ${ }^{48}$. Su trazado, una elemental planta de ciudad-itinerante como Castrojeriz, Redecilla del Camino o Los Arcos, consta de dos hileras estrechas y largas de parcelas iguales, de unos 6 metros de anchura y 25-30 de fondo, a ambos lados del camino, con la iglesia de la Asunción en el centro de un lado. Sabemos que en 1095 había en Canfranc un importante mercado, así como un albergue particular al servicio de los pobres y los peregrinos; Alfonso I dio al hospital Santa Cristina de Somport, distante 13 kilómetros, un palacio, un horno y un molino que tenía en Canfranc.

Según nos revela la vista del valle de Canfranc dibujada por Spannocchi en 1592, al menos hasta entonces la villa debía tener la mitad de longitud que en la actualidad, quedando la iglesia en un extremo y el castillo en el otro, ambos fuera del continuo parcelado. Posteriormente, las manzanas residenciales se duplicaron, dejando la iglesia en el centro. En la parte inferior de un plano del castillo de Canfranc, Spannocchi dibujó un tramo de la calle única, por el que sabemos que las casas eran, al menos en la porción croquizada, de una sola planta, separándose cada una de las de los lados por amplios vacíos cerrados por una tapia, que se utilizarían como corrales.

Jaca, primera sede episcopal aragonesa, constituyó una aplicación excepcional del fuero, ya que su plano tuvo una significación y una complejidad que excedía la simplicidad de los burgos de los siglos XI y XII. En I035, Jaca, la única villa algo importante del exiguo territorio aragonés ${ }^{49}$, constaba de un pequeño núcleo central habitado por villanos del rey (el llamado castrum), un núcleo exterior eclesiástico, centrado en el monasterio de san Pedro el Viejo (fundado a principios del siglo $X$ ) y un pequeño barrio mercantil, también aislado, a los pies del camino de Francia a Pamplona y Compostela, que incluía en 1035 una ermita de Santiago. Antes de 1077, debieron de formarse agrupaciones de casas adosadas a ambos lados

47 En 1077 o al comienzo de 1078, Sancho Ramírez estableció el hospital de Santa Cristina de Somport, en beneficio del tramo aragonés y en detrimento del que cruzaba el Pirineo por Roncesvalles.

48 Desde el mismo nacimiento de Aragón como reino independiente, se cobraban en Canfranc los peajes por el paso de las mercancías procedentes de Francia; estos aranceles aduaneros y el comercio favorecido por el paso continuo de mercaderes y peregrinos fueron los únicos medios de subsistencia de sus habitantes durante toda su historia, ya que la población estaba en un terreno incultivable.

49 Situada en la confluencia del camino de Santiago con el de Zaragoza a Francia, lo que le permitió mantener una relativa importancia durante la baja Edad Media. 
del camino que unía la villa regia con el barrio de San Pedro (actual calle de Bellido), con alineación simple de parcelas al sur y planta en espina de pez al norte.

Tras acumular la corona de Pamplona a la de Aragón, Sancho Ramírez acometió en 1077 la transformación de Jaca en sede episcopal -apenas seis años después de la introducción del rito romano- y única ciudad aragonesa ${ }^{50}$, iniciando la construcción de la catedral y, al mismo tiempo, promulgando el célebre fuero ${ }^{5}$. La catedral de Jaca y la ordenación urbana auspiciada por el fuero no sólo son dos obras estrictamente contemporáneas, sino elementos de un programa unitario. Los dos elementos que conforman la imagen de la Jaca de Sancho Ramírez son igualmente románicos y contienen potentes componentes simbólicos de la universalidad espiritual en que se inscribe el proyecto político del rey: la cuadrícula orientada, la cruz de calles equivalente al cardo y el decumano máximos, la cúpula semiesférica apoyada sobre cuatro arcos con el Tetramorfos sobre las trompas, el clasicismo de la escultura de la catedral o el mensaje cósmico de los crismones de sus puertas.
Todo viene a participar del mismo discurso regio ${ }^{52}$.

Catedral y manzanas del ensanche constituyen un único proyecto urbano. Las nuevas manzanas se extienden hacia el sur, rellenando huecos, prolongando y reinterpretando la Jaca preforal, absorbida por una nueva estructura potentemente formalizada y jerarquizada. La catedral, al norte del casco jaqués, se insertó en un tejido ya consolidado en 1077 , mediante una operación de vaciado y profunda reconstrucción de la parte más importante de la vieja villa, junto al monasterio fundacional de san Pedro y la entrada del camino jacobeo desde Francia; la plaza, los dos conjuntos religiosos y las edificaciones vinculadas a ellos, entre ellas un hospital de peregrinos anejo a la catedral, configuraron una ciudad levítica dentro de la ciudad $^{53}$.

Sancho Ramírez, el rey que consiguió que el papa llamara a los príncipes cristianos a cruzada contra Barbastro treinta y un años antes de la primera cruzada a Tierra Santa, que rindió vasallaje a Roma e introdujo el rito romano en Aragón, impuso a su capital una forma

50 La promulgación del fuero (enero o febrero de 1077) y la instauración de la sede episcopal (marzo de 1077) fueron fenómenos separados por días o semanas, lo que indica su complementariedad; no hay que pasar por alto, de todos modos, que el fuero, que afirma ser causa de la elevación de la villa a ciudad, es anterior. La poca solidez jurídica de esta elevación de rango -ni una sede episcopal podía implantarse en una villa ni el rey tenía capacidad para crear una ciudad, rango limitado a las civitates romanas- explica que, como observó SANGORRÍN (1920: I 17), "en cuanto la sede episcopal pasó a Huesca [1098], ninguno le da a jaca el título de Ciudad, sino el de Villa, en los dos siglos siguientes XII y XIIlı. Sancho Ramírez, que no contaba con ninguna civitas en Aragón, no podía hacer sino apoyar la ambigua capacidad de Jaca para ser sede diocesana provisional promoviendo la reproducción de las condiciones históricas de la civitas. Siguiendo los modelos próximos de Huesca, Pamplona y, sobre todo, Zaragoza, capital taifal cuyo contraste con la empobrecida vida urbana hispanocristiana era manifiesto, el rey intentó hacer de Jaca una población merecedora del rango de ciudad, por su nutrida población, por su riqueza, por su cosmopolitismo, por su composición social burguesa, por la exclusión de actividades primarias, por ser sede de instituciones rectoras civiles y eclesiásticas, y, también, por el prestigio arquitectónico de sus monumentos y por la forma deliberadamente urbana (romana) de su plano.

5I Aunque el fuero propició la adición de nuevos barrios burgueses a un castro poblado por campesinos y milites, no operó, como en Pamplona, Alquézar o Luesia, por adosamiento de nuevos burgos jurídicamente diferenciados, sino por absorción del castro por una nueva ciudad, a cuyo suelo se hizo extensivo el fuero sin excepciones. mediante el fuero, el rey intentó acrecentar el vecindario de laca, elevada de villa a civitas, sobre todo con nuevos pobladores dedicados a la artesanía, a la hostelería y al comercio; GARCÍA DE VALDEAVELLANO (1969: 134-135) puso de manifiesto que la nueva categoría de ciudad no debía proceder de los milites y rustici que ya poblaban la villa antes de 1077, sino de los burgensis que acudieran a la llamada del fuero desde el otro lado de los Pirineos: cuando Ramiro II exigió en I 37 que los aragoneses juraran fidelidad al príncipe Ramón Berenguer, el 78 '85 \% de los 600 u 800 habitantes de Jaca procedía de fuera de la península; había además un I'60% de judíos.

52 Parangonable al discurso de Mundir I y al-Muqtadir de Saraqusța, expresado en el palacio de la Aljafería y en la traza ortogonal de los nuevos ensanches meridionales.

53 Con su estructura tripartita original -atrio, naves y ábsides alineados longitudinalmente- y las proporciones de sus partes ( $2 \times 1$ en el atrio y en el cuerpo central, y $|x|$ en el ábside central), la catedral se asemejó, probablemente de modo intencionado, al templo salomónico descrito en el Antiguo Testamento, completando una hipotética lectura de Jaca como Jerusalén, vinculada a su papel de etapa inaugural del camino hacia Compostela, la Jerusalén de Occidente. 
deliberadamente latina, apoyada en la cruz de un cardo y un decumano, ejes que unen el centro del reino con los cuatro puntos cardinales en los que abstraía la referencia a la humanidad entera el comienzo del fuero de Jaca:

«In nomine Domine nostri Ihesu Christi et individue Trinitatis, Patris et Filii et Spiritu Sancti amen. Hec est carta auctoritatis et confirmationis quam ego Santius, gratia Dei Aragonensium rex et Panpilonensium, facio uobis notum omnibus hominibus, qui sunt usque in orientem et hoccidentem, et septentrionem et meridiem, quod ego uolo constituere ciutatem in mea villa que dicitur laka.»

La planta del ensanche promovido al sur del antiguo núcleo ramirense es una retícula de calles rectas y manzanas cuadradas. A diferencia de todas las fundaciones francas de la época, aquí no primó la lógica de la agrupación parcelaria, con sus características manzanas estrechas de longitud indefinida, sino la forma cuadrada de las manzanas, que resultaba ajena a los procesos de agrupación permitidos por los tipos edificatorios en la época. Esta falta de coherencia entre la agrupación parcelaria y la forma de la manzana sugiere una intención formalista e ideológica: la forma urbana jaquesa es premeditadamente romana -románica-, símbolo de la voluntad universalizadora que inspiró el fuero.

En el plano de Jaca se impuso lo ideológico, y no parece arriesgado buscar su inspiración en la cercana Zaragoza, la Cæsaraugusta romana y la Saraqusța taifal, llamada a ser algún día centro del reino de Aragón y hostigada por Sancho Ramírez desde 1081. La forma urbana de Zaragoza pudo ser vista como modelo para la nueva cabecera de un reino que nacía con la vista puesta en Roma, ciudad que el mismo Sancho I había podido admirar personalmente en su viaje de 1068.

Si Jaca estuvo sujeta a fuertes condicionantes representativos y simbólicos que la alejaron, paradójicamente, de la lógica genética de su fuero, al final del siglo Xl, mientras se consolidaba el ensanche foral, se formaron dos burgos mercantiles cercanos al mercado y a la catedral, pero dando la espalda al centro urbano formado en 1077. Integrado en el extremo nordeste del espacio foral, el burgo de San Nicolás, que incluía una iglesia homónima documentada en II04, fue una agrupación convencional de manzanas alargadas formadas por alineación doble de parcelas estrechas y profundas. Extramuros de la ciudad se había formado ya antes de 1135 el Burgonovo o Burnao, un arrabal mercantil y hostelero extendido a ambos lados del camino de Francia, que sí respetaba las características generales de las villas burguesas de la época. Además de una veintena de casas y algunas construcciones funcionales, existían en 1592 la iglesia de Nuestra Señora del Burnao y unas casas conventuales anejas.

Aun cuando no se sitúe sobre el camino de Santiago, sino sobre la ruta de Zaragoza y Huesca a Francia ${ }^{54}$, Ayerbe es otro ejemplo paradigmático de la ciudad burguesa de fundación en Aragón. Desde comienzos del siglo XI, había una población musulmana nacida al abrigo de un castillo desde el que se dominaba la vía que unía Zaragoza y Huesca con Francia; esta formación espontánea pervivió tras la conquista aragonesa, y es conocida aún hoy con el nombre de El Lugaré o barrio de San Benito; era un

54 Tras la conquista a los musulmanes de la línea Ejea-Huesca-Barbastro, y casi inmediatamente del valle del Ebro, los terrenos subpirenáicos de las Cinco Villas y los somontanos de Huesca y Barbastro pasaron a ser tierras de interior lejanas a la frontera. A partir de las décadas de I I 10-1 120, fueron objeto de una reestructuración jurisdiccional y productiva que incluyó la creación de una serie de núcleos mercantiles con análoga finalidad a la que desde 1077 se intentaba dar a los burgos creados en el entorno del Camino Francés, y para los que también se empleó con frecuencia el fuero de Jaca: Ayerbe, Alquézar, Aínsa, Luesia, Asín, los burgos de Uncastillo... Al sur de esta línea quedaban los territorios, más ricos, que habían estado sometidos a una intensa islamización, dotados ya de una estructura territorial que incluía verdaderas ciudades (Huesca, Zaragoza, Tarazona) y núcleos de población de cierta entidad (Ejea, Borja, Barbastro, Fraga, Calatayud, Daroca, Belchite, Tudela) rodeadas por algunos de los terrenos agrícolas más productivos de al-Andalus, donde el fuero de Jaca, un instrumento con el que se intentó crear mercados donde no había ciudades, será ya innecesario. 
castro típico, asentado en la ladera oriental de un cerro fortificado y surcado por calles longitudinales que seguían las curvas de nivel y partían de un eje central (la actual calle de San Benito) coincidente con la línea de máxima pendiente, que descendía desde el castillo. En el Lugaré estuvo la iglesia parroquial de San Pedro, la única de la villa durante toda la Edad Media.

Hacia I I22, Alfonso I concedió el fuero de Jaca a aquellos hombres que acudieran a poblar el Burgo Nuevo, que se edificó a partir de la parcelación de unos terrenos inmediatos a la confluencia de los caminos de Ejea y de Huesca hacia Francia. Se formó así un burgo mercantil de nueva planta, en llano, en un lugar privilegiado por el tráfico de viajeros y mercancías y a una cierta distancia del núcleo central de Ayerbe. Entre el Lugaré y el Burgo Nuevo quedó una amplia extensión sin urbanizar, ocupada por huertas de los habitantes del poblamiento preexistente ${ }^{55}$.

El Burgo Nuevo se ordena a partir de la estricta parcelación de manzanas rectangulares en solares estrechos y profundos, alineados medianera con medianera, a los lados del camino de Ejea, ahora convertido en calle del Barrio Medio; al mismo tiempo o poco después, se ordenaron de modo similar las calles paralelas de San Miguel y Nueva, al oeste y al este del camino, respectivamente. Entre estas tres calles, existía un número muy escaso de pasos transversales de rango marcadamente secundario. El carácter marginal del burgo, jurídica, social, económica y formalmente independiente del viejo Ayerbe, al que no se extendió el fuero de Jaca, se hace evidente tanto por la distancia que quedó entre ambos núcleos como porque el Nuevo no asumió ninguna función urbana representativa; en este barrio, poblado por francos, la homogeneidad de la estructura urbana y de la edificación doméstica era extrema: todas las parcelas eran idénticas y no existía ningún espacio o edificio representativo, ni siquiera una iglesia.
Emparentados con el de Ayerbe están los burgos nuevos de Alquézar, San Esteban de Luesia, y Santa María de Uncastillo, también barrios de nueva planta poblados a fuero de Jaca y adosados a poblaciones enriscadas sujetas a ordenamientos consuetudinarios; todos ellos se forman por alineaciones de parcelas en manzanas rectangulares alargadas, y configuran barrios morfológicamente diferenciados y físicamente separados de los castros matrices, con sus tradicionales estructuras radiocéntricas.

Un grupo aparte dentro de las fundaciones burguesas medievales aragonesas es el constituido por aquellas que, aun recibiendo fuero de francos por su función comercial preponderante, tuvieron fuertes condicionantes defensivos, conformando un grupo morfológico bien definido y presente tanto en Aragón como en el sur de Francia o en Navarra. Morfológicamente, se caracterizan por aunar una parcelación regular, fruto de la planificación, con una perfecta adaptación al terreno, en general una meseta de paredes escarpadas elevada sobre los campos de su entorno.

Aínsa, Berdún o Artieda prefiguran este tipo urbano, muy común en la Edad Media. Cantavieja, La Iglesuela, Castellote y otras fundaciones templarias y hospitalarias de la zona oriental de la actual provincia de Teruel presentarán modelos similares a mediados del siglo XIII. Durante la guerra contra los albigenses, Raymond VII de Tolosa fundará entre 1222 y 1249 las llamadas primeras bastidas, villas fortificadas emplazadas en altura que responden al mismo modelo ${ }^{56}$.

En I 127, Alfonso I otorgó a Aínsa el fuero de Jaca, acorde con su condición central en el Sobrarbe, que le daba una relevancia comercial de la que es testimonio su enorme y bien proporcionada plaza del mercado. Era también Aínsa un importante enclave defensivo, que contaba desde el siglo XI con un castillo, muy

\footnotetext{
55 Probablemente, el Burgo de I I 23 debió de extenderse algo más hacia el norte, ocupando al menos una parte de la posterior Plazo Mayor, que los Urriés urbanizaron en el siglo XVI como centro de su nueva planificación urbana.

56 Son muy conocidas Cordes ( I 222), Castelnau-de-Montmiral (ca. I 222), Penne-d'Agenais ( I 229), Lauzerte (I 24I) o Puymirol (I 246).
} 
ampliado a finales del XVI y comienzos del XVII para convertir la villa en un punto fuerte frente a Francia. La defensa condicionó el asentamiento sobre una meseta estrecha y alargada de difícil acceso, cuyos bordes coinciden en todo el perímetro con una hilera continua de viviendas cerradas hacia el exterior: ciudad y territorio se funden en una estrecha relación mutua. Junto a la puerta septentrional del recinto se erigió la colegiata de santa María, cuyo campanario fortificado servía como torre de vigía; junto a la puerta de Abajo, en el otro extremo, estaba la iglesia del Salvador, también románica. Inicialmente, entre la villa y el castillo quedaba un extenso yermo donde en el siglo XIV se construyó la conocida plaza porticada para albergar uno de los mercados más importantes de Aragón. Esta plaza, característica de las operaciones de reforma y ensanche urbano bajomedievales, responde a un nuevo y ambicioso concepto del espacio público, presidido por el orden geométrico y definido a través de la arquitectura.

El tipo de Aínsa se aplicó sistemáticamente en el área del camino de Santiago aragonés después de I 134. Desde 1076 a I| 34, cuando los reinos de Aragón y Pamplona permanecieron unidos y su frontera en paz, el estímulo comercial de la ruta francesa de Compostela se apoyó en la fundación de pequeñas poblaciones en sus márgenes, de acceso inmediato y sin fortificar. Ni Jaca ni ninguna otra población del camino contaron antes de II 34 con murallas, proveyéndose de elementales cercos sin capacidad defensiva, sólo erigidos con fines fiscales y jurídicos. Desde la muerte de Alfonso el Batallador en I I 34 hasta la conquista de Navarra en I 1 |2, los dos reinos permanecieron escindidos y su frontera se convirtió en permanente zona de conflictos.

Las confrontaciones fronterizas y, más aún, el interés de la monarquía feudal por agrupar la dispersa población de la Canal de Berdún en un corto número de núcleos fortificados desde los que se dominara un territorio rústico despoblado, provocaron grandes modificaciones en su paisaje urbano, con la concentración de la población en unas cuantas villas fáciles de defender, la fortificación de las poblaciones tradicionales mejor emplazadas (Jaca, Ruesta, Sigüés, Escó) y el abandono de asentamientos en llano junto a la ruta, a cambio de otros en altura, a la defensiva (Berdún, Mianos, Artieda, Tiermas, Salvatierra de Esca) ${ }^{57}$.

Entre 1134 y 1200, estas refundaciones en alto se realizaron por otorgamiento del fuero de Jaca, manteniendo las características sociales de la población pero adecuando su asentamiento a condicionantes defensivos perentorios, de acuerdo con el modelo desarrollado en Aínsa; así se repoblaron Berdún, Artieda y Mianos. A partir de 1200, se recurrió ya en esta área a cartas específicas para zonas de frontera, y el fuero de Ejea fue concedido para fomentar el cambio de emplazamiento a Obelva/Salvatierra y a Tiermas.

Berdún era una población nacida en el siglo $X$ y vinculada al comercio, que ocupaba tierras realengas junto a la ruta jacobea, al pie del mogote donde se encuentra el núcleo actual. En II34, los navarros la arrasaron y, en I I 38, Ramón Berenguer dispuso su reedificación, otorgándole el fuero de Jaca en II58. Dada la arriesgada situación de la villa, por su proximidad a Navarra, esta repoblación no se llevó a cabo en el lugar donde había estado el primer Berdún, sino en lo alto del cerro que lo dominaba, en una estrecha meseta plana bordeada por pendientes muy escarpadas. Abajo quedaron la ermita de Santa María de las Eras, algunas casas y la plaza del mercado, que seguía necesitando de la proximidad del camino y que tenía una importante actividad en el siglo Xll. El castillo no se construyó hasta el XVI, derri-

57 En Tiermas o en Berdún, se tiene la sensación de una alternancia en la posición urbana, en poblaciones que parece que, a lo largo de los siglos, han ido subiendo o bajando del cerro al camino y del camino al cerro, según el devenir de los acontecimientos. Para entender este fenómeno, hoy tan extraño, debe tenerse en cuenta que la construcción doméstica común era en los tiempos medievales de mala calidad y poco volumen, más fácil de abandonar y reedificar que de proteger. Las construcciones representativas, el castillo y la iglesia, permanecieron fijas en lo alto (aún hoy es común verlos aislados en un cerro, con el pueblo a los pies) o, en el caso del edificio eclesiástico, se duplicaron. 
bándose para ello doce casas del núcleo. En Berdún, las casas que forman el perímetro del núcleo urbano se cierran al exterior y cumplen las veces de la muralla. La iglesia de Santa Eulalia se incorpora al perímetro, reforzando la puerta principal, su punto más débil, y dignificando la entrada a la ciudad; la torre de campanas es también torre de vigía y defensa.

Como corresponde a una fundación a fuero de Jaca, aun en esta difícil implantación topográfica, todas las parcelas del nuevo Berdún fueron aproximadamente iguales, con planta estrecha y alargada: en el contorno, unos 5 metros de anchura por 17-20 de profundidad; el interior de la villa, de trazado más irregular, pudo ser ocupado en una fecha más tardía que su perímetro.

Desde mediados del siglo IX, Artieda consistía en una iglesia y un puñado de casas situadas en el terreno llano que bordeaba la ruta jacobea. Entre 1034 y 1037, este núcleo fue destruido en una incursión navarra, y la villa se reedificó en lo alto de un montículo muy escarpado, construyéndose también un castillo ya desaparecido. El nuevo Artieda presentaba una disposición similar a la de Berdún, con casas fortificadas que conformaban un característico perímetro triangular y la iglesia que protegía y sacralizaba la entrada desde el camino.

Como en los viejos dunum célticos, es una característica fundamental de este tipo de ciudades la prioridad de la construcción del anillo perimetral de casas sobre el caserío interior. Así, en Artieda, en un principio el área central debió quedar sólo ocupada por la propiedad señorial y la iglesia, manifestando el orden social imperante a través de un preciso orden urbano.

\section{Las ciudades regulares con fuero de Jaca en el camino navarro}

Debido a la pobreza del territorio que atravesaba y la situación bélica enquistada en la comarca desde 1 134, entre otros factores ${ }^{58}$, en el camino francés aragonés no han subsistido, aparte de Jaca, fundaciones urbanas relevantes. Perviven, en cambio, en Navarra tres villas de camino -Estella, Sangüesa y Puente la Reina- de indudable categoría urbanística, fundadas a fuero de Jaca por los reyes aragoneses entre 1077 y 1135.

Estella, la más antigua de ellas, recibió de Sancho Ramírez el fuero de Jaca en 1077, al mismo tiempo o casi inmediatamente después que la nueva ciudad aragonesa. El núcleo foral, conocido como burgo de San Martín, se situó al sur del río, a los pies del castillo real, donde tal vez hubiera ya un pequeño núcleo mercantil anterior a la fundación ramirense. Presenta una clásica estructura itinerante: una parcelación regular alineada a los lados de un tramo del Camino desviado ${ }^{59}$, convertido en calle y rápidamente poblado con posadas, tiendas y hospitales; en el centro de la calle se levantan, a uno y otro lado, el palacio real -un edificio del siglo XIl- y la capilla de San Martín ${ }^{60}$. Es un caso muy similar al de Canfranc, incluso en su apurado encaje en el territorio, que obligaba al caminante a atravesar la rúa de las Tiendas y que forzó a la población a saltar al otro lado del río Ega ya en la segunda mitad del siglo Xll.

\footnotetext{
58 El camino aragonés era un breve trecho de 85 kilómetros que nació como alternativa tardía al consolidado ramal de Roncesvalles y que pasó a ocupar una posición territorial marginal desde la conquista del valle del Ebro. Otra causa de su decadencia fue su estrecha vinculación con los monasterios cluniacenses, que desde el siglo XII se resintieron de una brusca caída de las donaciones, consumada con la fundación de las órdenes mendicantes a comienzos del XIII, y de la dificultad de atraer pobladores para continuar la colonización interior de sus dominios, ante la ventajosa competencia de la Tierra Nueva.

59 El rey llevó a sus tierras la población burguesa que los monjes de San Juan de la Peña pretendían hacer en Zarapuz, a 3 kilómetros de distancia hacia el sur, donde ya tenían un monasteriolo dependiente y un hospital de peregrinos; a cambio de la renuncia a fundar en sus dominios y del desvío a Lizarrara del Camino Francés que por entonces se estaba formando, los cluniacenses obtuvieron la concesión de la décima parte de las rentas reales y la propiedad de todas las iglesias que se construyeran en el nuevo burgo.

60 En 1135, el burgo de San Martín estaba formado, además de las casas de francos de la rúa, por las de los judíos que ocupaban los terrenos de mayor pendiente comprendidos entre la rúa y el castillo.
} 
Más compleja es la planta casi perfectamente regular de Puente la Reina, refundada por Alfonso I a fuero de Jaca en II22, en un lugar ya habitado por unos pocos mercaderes francos. La villa quedaba encajada entre un puente, por el oeste, y la confluencia de los dos ramales del Camino que cruzaban los Pirineos por Somport y Roncesvalles, al este: se buscaba que toda persona que recorriera la ruta jacobea atravesara la ciudad, para lo que ésta se rodeó por una cerca con sólo dos puertas en las que se percibían los peajes.

Con un contorno rectangular, el burgo se conformó a partir del tramo del Camino que lo atravesaba por su eje longitudinal de parte a parte -la rua maior-y una calle paralela a cada lado, algo más estrecha; hay otras calles transversales, la mayoría de mínima anchura y sin acceso a viviendas. Entre las calles, las manzanas son simples alineaciones de parcelas idénticas, muy estrechas y profundas. A lo largo del eje longitudinal se encuentran la plaza del mercado (en su estado actual, producto de una reforma urbana posterior) y la parroquia de Santiago, documentada en II42, alrededor de la que vivían los francos; otra parroquia, dedicada a San Pedro y también del siglo XII, ocupa la esquina sudoeste de la cerca, junto al río, en el barrio ocupado por los antiguos vecinos de la inmediata Murubarren, trasladados a la nueva población ya en II22. Vemos en Puente la Reina una elaboración muy sutil de la dualidad entre los barrios de francos y de indígenas que caracterizó las ciudades mercantiles navarras y aragonesas, debida en este caso a la simultaneidad y planificación conjunta de ambos establecimientos, que ocupan dos mitades equivalentes del plano.

Forma este plano un rectángulo muy alargado, de unos 120 metros de ancho por 340 de largo, excluido el contorno formado por estrechas parcelas adosadas a la muralla. El lado occidental de la plaza del mercado divide el lado largo en dos segmentos iguales, correspondientes a sendos rectángulos de unos 120 por 170 metros ${ }^{61}$. Cada uno de estos rectángulos debió de corresponder en origen a uno de los dos barrios (conocidos en el siglo XIII como de Romeros y la Navarrería) que componían la villa, que probablemente se separarían por una cerca ante cuya puerta se formó la plaza del mercado, regularizada ya fuera del período medieval.

Originalmente, Puente la Reina sólo se rodeó por una cerca, construida con fines fiscales; en 1235, esa cerca se había convertido en una verdadera muralla, con torreones cuadrangulares regularmente espaciados. Fuera de la cerca sólo se encontraba el hospital de peregrinos, avanzado en el Camino con respecto a la villa y situado justo en el encuentro de la ruta que llegaba de Somport con la que lo hacía de Roncesvalles; hacia él se produjo, ya en el siglo XIII, el único crecimiento del caserío, flanqueando la ruta jacobea.

El modelo urbanístico de Puente la Reina, de rara perfección, se repitió en muchas fundaciones erigidas en el siglo XII en el país vasco castellano, como San Sebastián, Vitoria o Laguardia.

Sangüesa es la ciudad navarro-aragonesa de trazado más complejo. A mediados del siglo XI existía ya un castillo en este lugar, a cuya villa le otorgó Sancho Ramírez el fuero de Jaca. A pesar de situarse en la misma entrada del camino francés en Navarra, la villa -en altura- no prosperó y Alfonso I volvió a darle fuero jaqués en I | 22. Para la refundación, se eligió un nuevo emplazamiento, inmediato al anterior, pero en llano y estratégicamente más adecuado; el Burgo Nuevo es una parcelación regular integrada en tres manzanas a cada lado del camino que llegaba de Tiermas, inmediata al puente de Santa María, sobre el río Aragón, y a un palacio de propiedad real emplazado junto a él, cuya capi-

6 Esto es, de proporción $1: \sqrt{2}$, un rectángulo muy fácil de construir sobre el terreno, cuyo lado mayor resulta de abatir la diagonal de un cuadrado formado a partir del lado menor. 
lla se reconstruyó como iglesia parroquial de santa María, en un extremo del caserío.

Pero tampoco el Burgo Nuevo tuvo demasiado éxito, y el mismo rey le concedió nuevo fuero en I 132, esta vez dirigido a trasladar ahí los habitantes del Burgo Viejo. Después de II35, Sangüesa creció gracias a la guerra y a su inmediatez a la frontera aragonesa, convirtiéndose en una importante plaza fuerte contra Aragón, enfrentada a las aragonesas Tiermas y Ruesta, con cuyo barrio bajo tiene una gran similitud formal.

La ciudad medieval quedó conformada definitivamente como un denso conjunto de manzanas rectangulares delimitadas por calles longitudinales paralelas al Camino y transversales casi perpendiculares y más espaciadas, rodeado por una muralla de contorno tendente al cuadrado. En el interior de la población no había plazas ni elementos significativos, situándose en posición perimetral diametralmente opuesta las dos parroquias de santa María (vinculada al burgo de I I22) y de Santiago (de la ampliación de 1132), integradas, a la manera habitual en el área navarro-aragonesa, en la fábrica de la muralla, junto a dos puertas a las que prestaron sus campanarios fortificados.

\section{Los ensanches de las ciudades aragonesas}

Cuando una ciudad como Huesca, Barbastro o Zaragoza era tomada, el suelo urbano y las huertas próximas pasaban a manos de los conquistadores. Un tenente del rey que operaba como señor de la ciudad, auxiliado por los partitores, repartía los inmuebles entre los señores que habían participado en la conquista, en proporción a su aportación; luego, éstos repar- tían el botín urbano con sus vasallos y favorecidos, lo que a veces supuso la captación de nueva población ${ }^{62}$.

Los pobladores que acudieron más adelante atraídos por los privilegios y la vida comercial de la ciudad ocuparon nuevos barrios extramuros en suelo de realengo. Los ensanches con que se recrecieron esas ciudades en los siglos XII y XIII no alteraron ni extendieron el orden jerarquizado del recinto central, sino que se adosaron como modos específicos de asentamiento. Se caracterizaron por la autonomía urbanística y la falta de cualidades formales, espaciales y funcionales capaces de competir con el centro urbano; sus elementales leyes de formación se limitaban a la lógica de agregación de la parcela medieval, estrecha y profunda, en manzanas rectangulares alargadas limitadas por angostas calles principales y transversales.

El más extenso de estos barrios es la Población del señor Rey (luego, San Pablo) de Zaragoza, creado para alojar a mercaderes, artesanos y hortelanos que vendían sus productos en el mercado, trasladado al lugar que aún hoy ocupa el Mercado Central por orden de Pedro II de 1210. Debemos relacionar el origen de este barrio, pronto el más poblado de Zaragoza ${ }^{63}$, con la extinción del régimen de señorío jurisdiccional a que estuvo sujeta la ciudad desde la conquista por Alfonso I y su concesión a Gastón de Bearn, con constitución de un concejo autónomo que en lo sucesivo se iría dotando de importantes privilegios ( I 199), y con la proclamación de Zaragoza, por bula de Inocencio III ( I 205) como sede de la coronación de los reyes de Aragón.

Las manzanas se forman por agrupación de dobles filas de parcelas iguales, de unos 6 metros

\footnotetext{
62 Poca, porque se evitaba atraer habitantes de los propios feudos, y, sobre todo, porque en la formación social feudal clásica las ciudades carecieron de la capacidad de absorber rentas, actividades y habitantes de que habían gozado en la sociedad tributaria mercantil islámica. La expulsión de los musulmanes no se vio seguida por una afluencia de nuevos pobladores capaz de ocupar las ciudades conquistadas, sometidas a una grave penuria demográfica; fruto de ello fue el abandono de extensas porciones urbanas, especialmente extramuros, y la promulgación por los reyes y los concejos de sucesivos privilegios para atraer población, en ocasiones específicamente burguesa; por poner un solo ejemplo, Pedro I concedió en I I00 ingenuidad, franqueza y exención de lezdas a los habitantes de Huesca y a quienes acudieran a instalarse en ella, por entonces muy mermada en su población; en II34, Ramiro el Monje añadió la reducción del servicio militar a tres días y la prescripción de año y día, originarios de las ordenaciones de francos.
}

63 En el siglo XV, residía en San Pablo la tercera parte del vecindario de la ciudad. 
de anchura y 25 de profundidad (unos $150 \mathrm{~m}^{2}$ ), medidas comunes en las parcelaciones medievales coetáneas y coincidentes con las de Laguardia (Álava; 1204) y Viana (Navarra; 1219), dos raros ejemplos del siglo XIII en cuyos fueros se fijó el tamaño de los lotes, de 3 por 12 estados (5'85 por 23'40 metros). En este ensanche no hubo al principio ninguna plaza ni espacio público relevante. El tejido viario forma una retícula de calles principales longitudinales y secundarias transversales, más estrechas y a las que recaían testeros $\sin$ accesos.

El barrio se completó con la implantación del convento de los dominicos entre sus manzanas y el Ebro, sobre el suelo de una antigua almecora islámica donde también se fundó la mancebía de la ciudad ${ }^{64}$. El convento, completado con una vasta plaza de predicación -la actual de Santo Domingo- y ampliado luego con el anejo femenino de Santa Inés (1299) y un hospital (|25|), fue un auténtico polo de desarrollo simbólico y asistencial del barrio, sin el que éste no puede entenderse ${ }^{65}$. Como el convento contemporáneo de San Francisco, el de dominicos no originó un nuevo arrabal, situándose al final del suelo ya parcelado en un barrio que interesaba potenciar. El convento no mantuvo una relación urbanística con la iglesia parroquial, centro simbólico y geométrico del barrio en cuyos confines se emplazó, sino, como era habitual, directamente con la Seo, al ocupar el extremo de la prolongación del decumano máximo romano, simétrico del emplazamiento original del convento de San Francisco 66.
Otro barrio zaragozano, el de San Miguel, fechable entre 1248 y 1260, se trazó en espina de pez con calle primaria preexistente de dirección este-oeste (el Coso) y siete secundarias norte-sur, un tipo característico del siglo XIII. Las manzanas, de unos 100 metros de longitud, se formaron por adosamiento de parcelas de unos 5 metros de anchura y de 16 a 21 metros de profundidad. Extramuros y bien dotado de agua, San Miguel albergó actividades molestas -sobre todo curtidurías-; en un principio, sus pobladores fueron cristianos, aunque los judíos abundaban ya a finales del siglo XIII, y a mediados del XIV ocupaban en exclusiva los tres callizos que conformaron la judería nueva (las actuales calles de Flandro, Hermanos Ibarra y Rufas). Se conformó así el barrio como una porción de ciudad sin autonomía formal: seis o siete manzanas accesibles por callizos que se comunicaban independientemente con el Coso -exterior al barrio-, algunas de las cuales podían incluso formar parte de la judería sin afectar al resto, ya que cada calle tenía sus propias puertas en los extremos. Como en otros casos, la iglesia parroquial de San Miguel de los Navarros queda en un extremo, sin articulación urbanística con el caserío.

En Huesca se ordenaron dos pequeños ensanches. El más importante era el del sur, desde la morería hasta el convento de Santa Clara, que, en realidad, correspondió a dos fundaciones sucesivas: la Población del señor Rey ( I25 I ) y la del Saco (I252). Por la misma época se desarrolló otro al este de la ciudad, que albergaba también una clase homogénea -labradores moriscos y, en menor medida, cristia-

64 Aunque la tradición situó el asentamiento de los predicadores en Zaragoza en 1219, la más remota constancia documental se remonta a una donación para la fábrica de su convento en 1227; el convento estaba en obras en 1250 y la iglesia parece haberse concluido antes de 1283. Por las mismas fechas se construyó la amplia iglesia de San Pablo, nueva parroquia de Zaragoza, sobre el solar que había ocupado la ermita de San Blas.

$65 \mathrm{Al}$ entregar a las dos primeras órdenes mendicantes dos amplios solares situados al final de los incipientes barrios de San Pablo y de las Eras -San Miguel no existía todavía-, las autoridades civiles quisieron utilizarlos como reclamos para atraer pobladores, además de centros religiosos y sociales de ambas extensiones urbanas. De la activa relación entre los conventos y la ciudad, y en particular sus elementos burgueses, da idea que el de Predicadores fuera desde 1262 la sede de la cofradía de Nuestra Señora de las Mercedes, que agrupaba a los mercaderes zaragozanos -San Pablo era un barrio mercantil y artesanal- y en el de San Francisco se constituyera, en 1383, la cofradía de Mercaderes Catalanes de Zaragoza.

66 En 1219, el rey autorizó a los franciscanos a instalarse al final del barrio de las Eras, en el otro extremo de la prolongación del decumano y también junto al muro de rejola. En 1286, los franciscanos se mudaron a las inmediaciones de la puerta Cineja del muro de piedra, y los agustinos reocuparon el solar del barrio de las Eras, cuyo desarrollo urbanístico y social había sido mucho menos satisfactorio que el de San Pablo. 
nos-, caracterizada por su marginalidad; el ensanche se situó al sur de un camino de salida de la ciudad -la actual calle de Lanuza- hacia el este, con manzanas muy regulares en espina de pez, a cuyas parcelas se accedía desde calles perpendiculares a la principal.

También Barbastro tuvo dos ensanches cristianomedievales, uno del siglo XII y otro del $X \mathrm{III}$, dispuestos el uno junto al otro en clara continuidad urbana. Toda la trama del primero, llamado de san Francisco y poblado tras la reconquista para alojar a los pobladores que no tenían cabida en el centro consolidado, se generó desde la plaza del Mercado, en el límite del arrabal oriental de la ciudad islámica. En el siglo XIII se formó un nuevo ensanche a los dos lados del camino de Monzón, también con parcelación regular y con esquema en espina de pez.

\section{Fundaciones mudéjares aragonesas}

Un tipo singular de asentamientos regulares medievales está formado por algunos enclaves establecidos en las márgenes del Ebro, la Huerva, el Jalón, el jiloca o el Cinca para el alojamiento de población mudéjar dedicada a la agricultura y la alfarería. La conquista cristiana de un territorio andalusí implicaba automáticamente la adquisición por la población musulmana del estatuto de elemento sometido, que en el orden territorial se manifestaba en su expulsión de las ciudades y en la prohibición de la propiedad de la tierra.

Los musulmanes debieron abandonar las ciudades inmediatamente o tras plazos más o menos cortos establecidos en las capitulaciones. La regla casi no conoció excepciones, y casi siempre los mudéjares -luego moriscos- de las ciudades reconquistadas vivieron confinados en morerías, barrios segregados emplazados generalmente extramuros.
La privación del derecho de propiedad inmueble obligó a los mudéjares a dedicarse a la artesanía, el comercio o el trabajo dependiente del campo. Aun en Valencia y Murcia, donde la permanencia tras la conquista de una nutrida población rural musulmana descartó su sustitución por colonos cristianos, las tierras fueron concedidas por los reyes a grandes señores feudales, laicos o eclesiásticos, de quienes los antiguos propietarios se convirtieron en aparceros o exaricos; a cambio de protección, los nuevos señores de la tierra fueron sometiendo progresivamente a los campesinos musulmanes un régimen señorial que se fue haciendo cada vez más gravoso (GUICHARD 1985).

Los nuevos señores aprovecharon la difícil situación de los moros que ni siquiera podían permitirse el exilio para fundar poblaciones rurales donde acoger a los que eran expulsados de las ciudades reconquistadas y quienes hasta entonces vivían en almunias dispersas. Ricos suelos de huerta se pusieron en explotación gracias a la colonización con sólo musulmanes, formalmente hombres libres que suscribían contratos agrarios colectivos con el señor y adquirían una condición semejante a la servidumbre, que les permitía seguir cultivando la tierra con la debida protección, a cambio de la apropiación señorial del excedente ${ }^{67}$ en condiciones tan ventajosas como sugiere el refrán recogido por Münzer «quien no tiene moro, no tiene oros.

Esto produjo una reestructuración de la forma musulmana de ocupar el territorio, sometida al nuevo orden en un equilibrio territorial peculiar; en las nuevas poblaciones, inmersas en territorios de señorío, los musulmanes pudieron mantener instituciones básicas como la del zalmedina o el almutafaz ${ }^{68}$. El viajero León de Rosmithal, que visitó España entre 1465 y 1467 , se sorprendió de encontrar en los alrededo-

67 A través de censos y monopolios de horno, molino o incluso baño, pretendiendo no pocos señores aprovechar el ritual musulmán para incrementar la renta feudal.

68 De Muel escribió Cock en 1585 que sus habitantes: «no comen tocino ni beben vino [...] Casi todos los vecinos de este pueblo son olleros, y todo el barro que se vende en Zaragoza lo hacen aquí [...] Tienen también su iglesia, pero muy poco visitada de los vecinos de ella, porque siempre está cerrada, si no es los domingos y fiestas, cuando por fuerza han de oir misa. Dijéronme que en todo el lugar no había más que tres cristianos viejos: el cura, el notario y el tabernero, el cual era también mesonero. Los demás irían de mejor gana en romería a la casa de Meca que a Santiago.» 
res de Zaragoza pueblos enteros de moros que mantenían sus costumbres, religión y modos de vida; el embajador veneciano Andrés Navagero (I524- I526) y Enrique Cock, que en 1585 acompañó a Felipe II a Zaragoza, Barcelona y Valencia, manifestaron igual sorpresa. Cuarte, Cadrete, María, Mozota, Botorrita, Muel, Nuez, Osera, Alfajarín, Villafranca, Torres de Berrellén, Sobradiel, La Joyosa, Urrea, Figueruelas, Bárboles, Bardallur, Ricla, Alfamén, Fuendetodos, Luceni, Letux, Lumpiaque, Alfocea, Calanda, Foz Calanda... son poblaciones que al final de la Edad Media estaban pobladas solamente por musulmanes, la mayoría de las cuales no existían siquiera cuando los territorios en que se ubicaban fueron reconquistados. De los treinta y seis núcleos de población enclavados dentro del término municipal de Zaragoza en el siglo XV, de dieciséis a diecinueve estaban poblados casi únicamente por moros.

Muchos de estos pueblos quedaron por completo deshabitados tras la expulsión de los moriscos en 1610, cuando salieron del reino de Aragón unos 70.000, la sexta parte de su población total y la mayoría absoluta en no pocas vegas de regadío, en particular a lo largo del Ebro y sus afluentes (DOMÍNGUEZ ORTIZ y VINCENT 1978: 194); en Gelsa, donde había mezquita pero no iglesia, fueron expulsadas las I 500 personas, de 33 I casas, que ahí vivían; en Cadrete fueron expulsadas unas 1000 personas, procedentes de 204 casas; en Cuarte, 1400. de 281 casas; otros 1000 en Muel, de 306 casas...

En ocasiones, los señores que fundaban un núcleo mudéjar para poner en explotación un territorio se limitaron a acotar una porción de su feudo como suelo urbano y dejar que los pobladores construyeran dentro sus casas. Pero lo normal es que, como en otras fundaciones feudales, el señor trazara una parcelación acorde con sus intereses. Estas parcelaciones eran por lo común regulares y homogéneas, ya que estaban destinadas a albergar una sociedad también homogénea, al igual que las morerías creadas ex novo en las ciudades reconquistadas. En muchas poblaciones mudéjares, como Gelsa, Alfajarín o Villafranca, se delata un plano regular, trazado según los procedimientos corrien- tes en el mundo cristianomedieval por el dueño de la tierra en la que se iba a recibir moros: si Alfajarín es una clásica ciudad itinerante, Gelsa se estructura sobre una cruz de calles. La comparación de esta última población con La Muela, una fundación ex novo del concejo de Zaragoza (I259), evidencia el parentesco de las plantas de algunos pueblos mudéjares con las de otros cristianos contemporáneos situados en el entorno de la capital aragonesa.

Sobre los lotes ordenados por el señor, podía ocurrir que los pobladores erigieran sus viviendas de acuerdo con modelos habitativos y constructivos mudéjares, dando a tales pueblas una muy peculiar condición mestiza. Pero esa autonomía, que era frecuente en las villas de fundación para colonos cristianos a los que se les cedían las parcelas en régimen de honor, no debió de serlo tanto en las pueblas de moros. Intervenía aquí el derecho dado a los pobladores sobre las parcelas: si ostentaban el dominio útil, lo normal es que cada cual construyera su casa; pero si eran meros aparceros que no ostentaban ningún título sobre el suelo y que ocupaban la villa de una manera más o menos precaria, era el señor quien se encargaba de construir y reparar las casas (TORRÓ 200I: 55I-552). Por tanto, muchas poblaciones de exaricos mudéjares debieron de contar, no sólo con parcelarios rígidos, sino con caseríos repetitivos, construidos directamente por el señor, que a veces utilizaba como mano de obra a quienes finalmente iban a ocupar las viviendas.

Aun en los casos en que los constructores y sus técnicas constructivas fueran mudéjares, no debió de estar en su mano decidir la forma y el tamaño de las casas, que, a diferencia de las villas para colonos cristianos, no solían pertenecerles; por supuesto, tampoco participaban en la parcelación del suelo ni cabe suponer que, una vez distribuido éste, pudieran operar los mecanismos de herencia del derecho māliki para deformar el parcelario fundacional. A pesar de que tanto las capitulaciones como numerosos privilegios posteriores reconocieron a los mudéjares el derecho a continuar fieles al Corán y a regirse conforme a la sūnna, lo cierto es que la ciudad mudéjar ya no era, 
como la islámica, la consecuencia del juego autónomo de las relaciones de vecindad sometidas a las normas del derecho civil, sino de una rígida asignación parcelaria oroginaria, efectuada por el señor fundador.

Estamos, pues, ante fundaciones cuya rigidez debió de ser todavía mayor que las villas cristianas donde el poblador disponía de un derecho de uso indefinido sobre la heredad y de la propiedad de la casa construida en ella. Advertido esto, se comprende que los pobladores mudéjares que acudían a las pueblas de aparceros no debieron de llevar consigo estructuras sociales anteriores para reproducirlas aquí. El señor estaba interesado en atraer familias nucleares a las que entregaba parcelas dimensionadas para construir sus pequeñas casas, de modo que huelga rastrear estructuras gentilicias de organización del espacio.

Conviene tener presentes estos elementos teóricos para abordar el estudio de las numerosas poblaciones mudéjares aragonesas, campo de trabajo hasta hoy prácticamente inexplorado -o explorado a ciegas- que en el futuro podrá aportar interesantes perspectivas al estudio del urbanismo planificado de la baja Edad Media y el Renacimiento.

\section{COMPLEJIDAD Y HETEROGENEI- DAD EN LA CIUDAD MEDIEVAL}

\section{Formaciones heterogéneas de frontera}

A diferencia de las cartas de francos, otros fueros, de los que el más antiguo es el dado a Alquézar en 1069, favorecieron actividades no mercantiles y tampoco urbanas, en particular la ganadería y determinados tipos de cultivo como el viñedo. Con ellos, se quería compensar la participación en la reconquista de señores laicos y eclesiásticos, órdenes militares e infanzones que no tenían cabida en el norte y que tampoco buscaban privilegios burgueses, sino la creación de un patrimonio. La promulgación del fuero atraía a nobles, infanzones y hombres dispuestos para la guerra que, por sí mismos o median- te sus vasallos, garantizaban la efectividad del asentamiento como base militar.

Un grupo elemental de fundaciones de esta familia está formado por las pequeñas villas inmediatas a la frontera navarra que recibieron fueros derivados del de Ejea para el reparto de su alfoz entre agricultores y ganaderos dispuestos a hacer la guerra; con ellos no se persiguió tanto importar colonos de regiones remotas, como concentrar la población antes dispersa en un número limitado de enclaves, adecuados a los intereses militares y, más aún, productivos, fiscales y políticos del sistema. Salvatierra de Esca recibió el fuero de Ejea en 1208; se dieron parcelas urbanas y rústicas de doble tamaño a quienes tuvieran caballo que a los peones, y se condicionó el derecho a vivir en la villa y a gozar de los privilegios forales al deber de participar en las acciones de armas a que se fuera convocado; los pobladores debían residir continuamente en la villa y cada casa debía mantener un hombre siempre dispuesto para la guerra. Con estos privilegios se sustituyó la vieja Obelba, una pequeña población en llano documentada en el año 890, por una modélica plaza fuerte planificada que recuerda a las más tardías bastidas francesas, donde se establecerían además familias campesinas del territorio. Salvatierra presenta un característico contorno rectangular alargado, correspondiente a una meseta escarpada, con calles rectas paralelas y perpendiculares, e hileras de parcelas de 12 metros de profundidad y 5 ó 10 de anchura, según se hubieran dado a peones o a caballeros; las parcelas dobles ocupan los lugares más privilegiados del núcleo medieval: próximas a sus flancos y a los lados de la calle Mayor. El acceso a la villa se produce por la mitad del flanco oriental, y queda protegido por la iglesia de san Salvador, cuya torre fortificada domina el camino y el acceso. En el extremo norte, de peor defensa, se emplazó el castillo, construido, quizá sobre una fortaleza anterior, por los invasores franceses que tomaron la villa en 1289 para no abandonarla hasta tiempo de Juan I.

Muy interesante es la planta del Pueyo de Tiermas, que recibió el fuero de Ejea en I20 I para atraer a una meseta de paredes muy ver- 
ticales y contorno fortificado a los habitantes del Burgo Nuevo de Tiermas ${ }^{69}$ y de varias aldeas vecinas ${ }^{70}$. En su planta actual se distinguen varias células de colonización, análogas a las jittāat de las ciudades campamentales islámicas, en que se agruparon los colonos procedentes de las diversas aldeas, formando pequeños recintos dentro del recinto amurallado común; cada una de estas células estaba formada por casas prismáticas aisladas que rodeaban un espacio libre colectivo y daban la espalda al exterior; entre ellas quedaron espacios intersticiales que con el tiempo se fueron colmando, para formar las calles estructurantes del conjunto. Este modelo se reprodujo en las villas concejiles del sudoeste del reino, a escala mayor tanto por lo que se refiere al tamaño de los barrios como a la distancia de captación de colonos.

Si la repoblación del norte se había apoyado en núcleos urbanos más o menos autónomos gracias a su función comercial o defensiva $o$ al cultivo de un alfoz inmediato, en el sur de Aragón se utilizaron modelos característicos de las extremaduras, basados al oeste en la creación de unas pocas, extensas y potentes comunidades concejiles, $y$ al este en la entrega de extensos territorios a poderosos señores feudales -sobre todo, órdenes militares-, para que procedieran a su colonización y explotación, con la necesaria creación de un hábitat concentrado.

Exceptuado el Bajo Aragón, la actual provincia de Teruel era un vasto territorio agreste y casi vacío. La repoblación no fue acometida directamente por la Corona, sino por unos poderes subalternos con gran autonomía a los que daba la capacidad de ordenar el conjunto del territorio, planificar su explotación y defensa, y fundar en él las poblaciones que estimaran convenientes, atrayendo hacia ellas habitantes que adquirían una condición vasallática, pero a los que se daban importantes privilegios.

En la zona occidental de la actual provincia de Teruel y suroeste de la de Zaragoza, la Corona auspició la creación de las cuatro grandes comunidades concejiles de Calatayud, Daroca, Teruel y Albarracín, inspiradas en el modelo de la extremadura castellana. Un extenso territorio era así colonizado y gobernado desde la villa cabecera, con miras a la óptima expolotación agropecuaria y a la defensa.

La zona sudeste del actual Teruel tenía características muy diferentes. Lindante con la Valencia todavía musulmana, no era una frontera estabilizada, sino un frente en progreso, desde el que los grandes poderes del reino, bajo la dirección de la Corona, debían acometer la expansión hacia Levante. Este amplio territorio se repartió entre unos poderes feudales expansivos de naturaleza supralocal e incluso supranacional, dispuestos y capaces para una colonización de esta índole: fundamentalmente, las órdenes militares ${ }^{71}$, la iglesia y algún representante de las familias más poderosas del reino ${ }^{72}$.

Mediante una carta ad populandum, la Corona entregaba un territorio prácticamente virgen a un agente con capacidad para colonizarlo, construyendo castillos, dividiendo y repar-

69 Una población en el llano, inmediata al río Aragón, a unos baños de origen romano que citó Aymeric Picaud y a la confluencia de los dos ramales aragoneses del Camino Francés antes de entrar en Navarra.

70 Sin demasiado éxito. Todavía en 1363 y de nuevo infructuosamente, Pedro IV llamó a los habitantes de Escó, Undués y Lerda para que abandonaran estas poblaciones y se instalaran en el Pueyo de Tiermas.

7I Las grandes órdenes internacionales -Hospital y Temple-, las peninsulares -Santiago y Calatrava- y también el fallido intento de orden aragonesa de Monte Agudio-San Redemptor. Había una clara intención de diversificar el dominio de la zona, de modo que ningún beneficiario pueda adquirir un poder excesivo.

72 Aliados y no enemigos de la Corona en la nueva concepción del estado y de su relación con la nobleza, la población y el territorio. A los reyes de la dinastía barcelonesa no les interesaba que la nobleza que se había consolidado en el viejo reino extiendiera sus privilegios y pretensiones hacia el sur. En cierto modo, la monarquía sustituyó un modelo personalizado de ocupación, dominio y expansión, por otro territorializado, paralelamente a la sustitución del concepto del rey como primus inter pares por otro en el que ejerce su poder sobre el territorio por derecho divino, manifiesto en el concepto del mero imperio. La idea patrimonial del reino ha dejado paso a otra territorial. 
tiendo las tierras, promulgando cartas de población y trazando caminos; la colonización se resumía en fortificar, organizar la producción agraria y poblar.

En los nuevos pueblos se asociaron dos sistemas generativos diferentes y orgánicamente yuxtapuestos: la parcelación homogénea, que los emparentaba con las villas burguesas de planta reticular, y la simbolización espacial del poder político-religioso de la orden, emparentada con las formaciones castrales radiocéntricas del norte. Una constante de estas nuevas poblaciones es la expresión plástica de la sumisión absoluta del caserío, asentado sobre un parcelario homogéneo, al castillo o palacio señorial, emplazado en la cima del terreno. Entre el castillo y las viviendas aparece la iglesia parroquial, casi siempre situada justo a los pies de aquél, como segundo elemento dominante que nunca es legible como un elemento integrado en el caserío, sino como tentáculo que emana de arriba ${ }^{73}$, como corresponde a estas villas de señorío eclesiástico. La simbolización urbana del poder no opera ya por oposición entre monumentos ordenados y caserío desordenado -esto es, como una conjunción aestética de opuestos-, a la manera de las villas altomedievales, sino mediante un orden global generado a partir de los elementos primarios del castillo y la iglesia.

La identificación del poder espiritual y el señorío terrenal se manifiesta en la aprehensión simbólica de la muralla y, en particular, de sus puertas. Es conocida la sacralización de la muralla en las sociedades tradicionales, en tanto que frontera entre el espacio urbano ordenado y aprehendido, y el mundo exterior des- conocido y caótico ${ }^{74}$. En las ciudades militares y eclesiásticas del sur, donde la muralla tiene una importancia defensiva real, su sacralización se realiza mediante técnicas arquitectónicas muy elaboradas que también estarán presentes en las ciudades y aldeas de las comunidades concejiles; es frecuente la asociación de las puertas de la muralla con iglesias que las refuerzan física y simbólicamente ${ }^{75}$; en muchas ocasiones, las mismas puertas se sitúan bajo torres y capillas abiertas.

Frente al acomodo espontáneo al terreno de las viviendas en las formaciones de castro y villa, en las poblaciones que estamos estudiando se verifica una parcelación del área doméstica tan regular como es posible ${ }^{76}$ y homogénea, de acuerdo con la condición jurídica y social de sus habitantes. La edificación residencial no envuelve espontáneamente el centro, sino que forma un conjunto autónomo, aunque situado a los pies de las sedes del poder. Esa regularidad parcelaria es visible en Villarluengo, en La Iglesuela, en Tronchón, en La Cuba, en Cantavieja, en Mirambel o en La Ginebrosa, entre las fundaciones templarias; en Castellote, del Redentor y luego del Temple; en Alcañiz o en Alcorisa, de Calatrava; tampoco está ausente en buena parte de las villas arzobispales del área, como Valderrobres, Linares o Puertomingalvo, o en otras de señorío laico.

\section{Las villas concejiles}

Características peculiares presentan las grandes comunidades concejiles del sudoeste, área fronteriza con Castilla ${ }^{77}$ que la Corona confió a cuatro concejos encargados de organizar la

\footnotetext{
73 La parroquia puede aparecer en simbiosis con el palacio, como dos expresiones de un mismo poder, a la manera de Valderrobres - una fundación del arzobispado de Zaragoza-, o bien, como en Linares de Mora, situada un peldaño por debajo del castillo, pero por encima del caserío, como un elemento por el que el primero se acerca al segundo.

74 Estudios de antropología del espacio como el conocido Lo sagrado y lo profano, de Mircea Eliade, exponen la preponderancia en la representación del espacio sacralizado del límite y el centro, a su vez relacionado con la cima.

75 Esta práctica estaba también generalizada en las villas situadas junto a la frontera navarra, como Ejea, Berdún, Artieda o Salvatierra.

76 Predominan los asentamientos en ladera pronunciada, a diferencia de los terrenos llanos preferidos por las villas burguesas, donde la defensa y el aprovechamiento agrario del suelo eran condicionantes menos decisivos.

77 Una frontera que ya no tenía expectativas de avance, a diferencia de la oriental.
} 
defensa y la explotación agropecuaria de extensos territorios poblados por aldeas. Dictó para ello ordenamientos inspirados en el fuero castellano de Sepúlveda (I076) y en el desarrollo que le imprimió su propagación a lo largo de la móvil frontera entre Castilla y el Islām durante los siglos XI y XII.

Cada uno de estos territorios se constituía en una comunidad de tierra y villa, que agrupaba multitud de aldeas gobernadas por la villa cabecera con una gran autonomía. Todo el territorio se atenía a un mismo fuero y, en un principio, su dependencia respecto de la villa era tal que es lícito hablar de señorío de ésta. Esta subordinación, tomada de Castilla, duró en Aragón hasta mediados del siglo XIII, cuando el creciente malestar entre los aldeanos por el dominio de las cabeceras se decantó en el reconocimiento jurídico de la comunidad, agrupación de todas las aldeas del término, excluida la villa. Hasta entonces, villa y aldeas conformaban una única entidad jurídica; desde ese momento, y sólo en Aragón, las comunidades de aldeas se fueron desvinculando progresivamente de las villas cabeceras para adquirir una considerable autonomía ${ }^{78}$. A pesar de esta emancipación jurídica, villa y aldeas siguieron vinculadas en lo militar, continuando la primera como núcleo rector de la defensa del territorio, presentando las mayores fortificaciones, pagadas con la contribución de las aldeas.

Cada territorio de extremadura era una isla de libertad a la que afluían gentes de procedencia heterogénea que, una vez ahí, quedaban sometidas a un estatuto jurídico igualitario. Gracias a los fueros, todos los colonos accedían a la condición de hombres libres, francos e ingenuos y se veían inmersos en una estructura social en la que no se reconocían privilegios a ningún hombre sobre los demás, fuera plebeyo, noble, clérigo o incluso judío o moro. En toda la extre- madura se pusieron importantes trabas a la penetración de la nobleza; la prohibición a los nobles de ocupar cargos públicos y de construir palacios ${ }^{79}$ garantizaba que, en el caso de que acudieran a estos territorios, no pudieran hacer efectivo un privilegio superior al de los demás vecinos.

A partir del igualitarismo inicial, las diferencias económicas entre los pobladores fueron apareciendo y acentuándose; durante los siglos XII y XIII, los caballeros -que llegaron a constituir un grupo con clara conciencia de claseadquiririeron la hegemonía económica, social y política, como consecuencia del interés de la Corona en favorecerlos con importantes exenciones fiscales; progresivamente, fueron haciéndose con el control de los cargos públicos, que adquirieron una condición de hecho casi hereditaria. El ascenso de la caballería villana implicó la transformación de unas sociedades de parentelas, basadas en la relación entre las familias, en sociedades de linajes, donde un determinado estamento ejercía el dominio político y económico.

El inicio del proceso de diversificación social en la extremadura radicó en la guerra, que proporcionaba pingües ingresos a los caballeros $y$, en menor medida, a los peones. Los fueros de frontera establecían una precisa regulación de la acción bélica, de las obligaciones de cada cual y del reparto del botín. Las expediciones bélicas concejiles, a las que cada familia debía enviar un hombre sano, proporcionaron nutridos botines, que financiaron las grandes obras públicas -murallas, catedrales, iglesias, sedes de las instituciones civiles- erigidas por los concejos en los siglos XII y XIII. Fruto de esta condición guerrera y de los vastos términos rurales encomendados a las villas cabeceras fueron los potentes recintos amurallados con que se rodearon, que simbolizaron el prestigio de la población.

78 Estas comunidades jurídicamente autónomas fueron reconocidas en I248 (Daroca), I254 (Calatayud), I277 (Teruel) y 1284 (Albarracín, en este caso, ya desde su misma incorporación al reino y la concesión de fueros).

79 En las villas no podía haber más palacios que los del rey y el obispo, entendiéndose por palacio, no una construcción suntuosa, sino aquella edificación, reducto de ciertos privilegios individuales, donde las autoridades concejiles no podían «entrar a prendar impunemente». 
Las murallas no sólo defendían la villa a la que rodeaban; debían acoger en extensos yermos interiores las familias y ganados de los campos cercanos, con los pastos necesarios en caso de asedio ${ }^{80}$. De ahí las grandes dimensiones de los recintos fortificados: el de Calatayud comprendía unas 50 hectáreas, el de Daroca 55, el de Teruel 17 y el de Albarracín 12. Las murallas eran pagadas proporcionalmente por todas las colaciones del casco urbano, y dejaban fuera a los barrios que se negaban a pagar ${ }^{81}$.

Junto a múltiples disposiciones relacionadas con la guerra, los fueros de frontera favorecían la colonización territorial ${ }^{82}$, el asentamiento y la reproducción de la población, y regulaban la convivencia, presumiblemente difícil, entre los vecinos. El primer objetivo se conseguía mediante la protección de la familia y de la propiedad privada.

Las heredades de todo vecino eran poseídas libre e ingenuamente, pudiendo venderlas, donarlas o gravarlas sin ninguna traba; más allá del reparto igualitario realizado por los quiñoneros, la facultad de concentrar propiedades animó el emprobrecimiento de unas familias y el enriquecimiento de otras. En su propiedad, un vecino podía construir libremente hornos, baños, tiendas, molinos o canales; en su casa podía denegar el alojamiento a cualquier caballero, noble o plebeyo, lo que era importante por lo que a la comitiva real se refería. En lugar de la prescripción de año y día de las ciudades burguesas, se prescribía el plazo de medio año tras la adquisición de una heredad, pasado el cual no se debía ya responder ante nadie por ella. En fueros como el de Teruel, se eliminó explícitamente la mañería, tributo que debía pagarse al rey para transmitir la heredad a un tercero por herencia cuando se carecía de descendencia directa, lo que acostumbraba implicar el paso de los bienes privados a manos de los monarcas. Se vislumbra ya el reflejo jurídico del proceso de privatización del suelo de realengo que tuvo lugar en la baja Edad Media, paralelamente a la desaparición del concepto patrimonial de la monarquía, que irá llevando a la ciudad fragmentaria, heterogénea y disgregada de la modernidad.

La familia adquirió un importante papel social. Se transfirió a los familiares los mecanismos de ejecución de la justicia, consagrándose el derecho a la venganza de la parentela del agraviado. En su casa, el individuo no podía ser detenido ni cercado y encontraba la seguridad que le daba su familia. A cada poblador le interesaba adscribirse al grupo más amplio posible, lo que daba lugar a una ciudad segmentada en barrios o colaciones donde se agrupaban los pobladores según su procedencia -navarros, serranos, francos, mozárabes...-, estableciéndose vínculos familiares en sentido extenso: un modelo no muy lejano de los asentamientos campamentales-gentilicios de los primeros tiempos de la expansión islámica. Sobre la base del barrio, elemento generativo y unidad básica social administrativa, las villas cabeceras de la extremadura se configuraron como ciudades-mosaico.

La fundación de una villa concejil comenzaba con la construcción de la amplia muralla $y$, en su interior, una estructura primaria de calles que unían las puertas del recinto, quedando entre ellas los espacios en los que se

80 Aunque se fortificaban también, con menor potencia, las aldeas más lejanas o más importantes.

8I Consta que cuando se construyeron las murallas de Teruel, se excluyeron dos barrios por no pagar las contribuciones. La noción de espacio intramuros y arrabales en las tierras de la extremadura tuvo un valor diferente del que tenía en las ciudades burguesas e infanzonas, no verificándose una discriminación originaria, pero sí otra según la disposición de cada grupo de pobladores a integrarse solidariamente en la comunidad del concejo y afrontar las obligaciones económicas que ello suponía. Este proceder ilustra acerca de la estructura social presente en estas ciudades de frontera, heterogénea y equiparable a un agregado de núcleos menores que estaban juntos pero no revueltos: más que partes derivadas de la subdivisión de una unidad inicial, sus barrios eran los componentes primarios que, más por yuxtaposición que por integración, generaban el conjunto.

82 Se favorecía el cultivo de la tierra yerma por la adopción de disposiciones como la de su adquisición por el simple hecho de su puesta en cultivo. 
formarían los distintos barrios. Cada uno, separado de los demás mediante espacios libres de mayor o menor extensión, se organizaba como una especie de microciudad con gran autosuficiencia, con su parroquia y su cementerio privativos y con una geometría urbana más o menos autónoma. Había tantos barrios y parroquias como grupos diferenciados de pobladores, sin una correspondencia con el tamaño de la ciudad en la misma proporción que en las ciudades del Ilano. En 1253, Calatayud tenía quince parroquias intramuros y una extramuros, y ya en I 196 Teruel tenía nueve, algunas de las cuales debieron acoger a un número muy reducido de parroquianos, a juzgar por su proximidad. Desde la conquista ( I 120) hasta | | 42 83, Daroca sólo tenía una iglesia, la de Santa María; a pesar de su reducido vecindario, la promulgación del fuero concejil de I I 42 llevó a la constitución, entre esta fecha y I I 96, de nueve parroquias más, además de la mezquita y la sinagoga; conforme la estructura de barrios definidos por el origen de los pobladores vaya dejando paso a otra de hecho jerarquizada, la estructura parroquial irá cambiando: hacia 1230, habrá sólo siete parroquias, que en 1905 se redujeron a una, la colegial de Santa María.

Teóricamente, en la ciudad concejil todos los barrios eran equivalentes y no había diferencias jurídicas entre los pobladores; aragoneses, castellanos, navarros, gascones, mozárabes e incluso judíos y musulmanes se colocaban en pie de igualdad sobre el suelo urbano, generando barrios yuxtapuestos, más que sometidos a una jerarquía urbana superior o a un orden común.

De las cuatro villas cabeceras de la extremadura aragonesa, Teruel es la que muestra una estructura polinuclear más pura, puesto que es la única de fundación aragonesa, proviniendo las otras tres de la adaptación de poblaciones musulmanas de cierta importancia. En su plano se observa esa fragmentación con cierta claridad a pesar del relleno que ha ido colmando los espacios vacíos que en su día quedaron entre los barrios. En Teruel, el centro no está resaltado por ningún edificio que imponga una jerarquía a toda la ciudad, como ocurre en las ciudades nobiliarias, pero, a diferencia de las burguesas, el centro existe: es un vacío ${ }^{84}$ que albergaba el mercado, la única actividad capaz de aglutinar al conjunto de la ciudad y desbordar el ámbito de sus barrios.

De cada uno de los tres vértices del triángulo de la plaza del mercado parte una calle de cierta importancia que lleva a un portal de la muralla: la puerta de Zaragoza, al este, la de Valencia, al sur, y la del Guadalaviar, al oeste; cada una de estas dos últimas calles cuenta, cerca de la puerta correspondiente, con un paso cubierto bajo un campanario parroquial. Aún sale del frente suroeste de la plaza una cuarta calle que lleva directamente al Portillo, abierto en la muralla al sur del portal del Guadalaviar.

El eje de dirección este-oeste que une las puertas de Guadalaviar y Zaragoza, con centro la plaza, divide el recinto urbano en dos zonas bien diferenciadas: la septentrional es más o menos llana, mientras la meridional tiene un relieve más pronunciado, en descenso desde el flanco oriental de la muralla. En correspondencia, la zona norte de la ciudad exhibe un trazado muy regular de calles en dirección norte sur que desembocan en el eje dorsal citado, mientras en la zona sur el callejero se condiciona por las curvas de nivel, apartándose mucho de la geometría regular en la zona oriental, la más empinada, y recobrándola, en la medida de lo posible, en la zona occidental, donde la pendiente se mitiga. A partir de aquí, se estableció una muy clara correspondencia entre características topográficas, regularidad de la traza y posición social de los ocupantes.

83 Antes de I 129, Daroca recibió un fuero de tipo militar, similar a los otorgados en el valle del Ebro; su fracaso llevó a la promulgación de un fuero de extremadura en I 142 .

84 La actual plaza del Torico. 
Los barrios más acomodados ocuparon la mitad septentrional de la ciudad. El de Santa María, el más rico, se vincula a la plaza central y a la calle que la une con la puerta de Guadalaviar; el de San Miguel conecta directamente con el otro tramo del eje principal, que va de la plaza al portal de Zaragoza, y los dos barrios juntos ocupan el centro de la zona norte de Teruel, cuya periferia, aledaña a la muralla y alejada de los ejes estructuradores, queda para la morería chica (en torno a la mezquita, más o menos en la actual Casa de la Cultura) y los más humildes barrios de Santiago y San Martín. En la zona sur, quedan los barrios de San Pedro, San Andrés, San Esteban y San Juan, más populares y ya sin una relación directa con el citado eje central, estructurándose a partir de calles procedentes de la que lo liga con el portal de San Esteban; al reducto más alto y tortuoso de esta zona meridional quedó relegada la judería, estructurada en calles radiales que no se abren al conjunto urbano. Por fin, encastrado entre ambas zonas y unido directamente a la plaza del mercado, queda el barrio de El Salvador, destinado a un sector social más acomodado, en razón de su ubicación.

La planta de Teruel evidencia una estructura fragmentaria, compuesta por diversos órdenes parciales yuxtapuestos pero no integrados; la mayoría de las calles son rectas y se entrecruzan ortogonalmente, pero el orden interno de cada barrio es independiente del vecino. Cada uno se centra en su parroquia, con una plaza, siempre bastante regular, ante su portal. Varias de las parroquias se sitúan junto a la muralla $y$, preferentemente, cerca de alguna puerta, identificando la entrada más como penetración en el barrio que en la villa ${ }^{85}$. Muchas de las iglesias fundadas en Teruel durante la Edad Media tuvieron torres en las que un arco abierto en su planta baja cubría una calle: San Martín, El Salvador, San Juan (cuyas tres torres cubrían calles de entrada a la ciudad), San Pedro y Santa María (donde cubrían calles de acceso al barrio).
El carácter descentralizado de la villa se evidencia en el hecho de que no dispusiera de ninguna iglesia capaz de aglutinar a todos los pobladores, reduciéndose el culto a las parroquias ${ }^{86}$; ya a lo largo del siglo XIV, la parroquia de Santa María de Mediavilla fue asumiendo un papel supraparroquial, elevándose a colegiata en I 342 y a catedral en I577: una evolución lógica, ya que se trataba de la iglesia del barrio más rico de Teruel, la más capaz y la más céntrica, próxima a las casas del Concejo y de la Comunidad. Conforme la población turolense se iba integrando en una colectividad -y conforme se iban consolidando unas nuevas formas de dominio-, iba unificándose la ciudad, con disolución de su fragmentación inicial.

\section{El urbanismo gótico}

En los siglos XIII y XIV, las ciudades de alguna importancia evolucionaron hacia una mayor complejidad social, por efecto de la emergencia del capital mercantil y del retroceso de la pequeña propiedad campesina, que envió a las ciudades contingentes de desposeídos. Hasta el año mil, la riqueza se asociaba al poder político y a la posesión de la tierra, lo que implicaba una estrecha correspondencia entre la jerarquía urbana y los poderes político-jurisdiccionales que operaban en la ciudad y el territorio; a partir del siglo Xl, la creciente mercantilización de la economía produjo una pérdida de cualidad social y política de la riqueza, que se fue emancipando de los privilegios jurídicos para consistir en posesión de moneda. En el siglo XIII, los comerciantes y los banqueros dejaron de ser considerados elementos marginales e incluso execrables de la sociedad; gracias a la institución, por entonces, de la confesión individual, el testamento obligatorio -con un mínimo diez por ciento para la Iglesia- y el Purgatorio, un infierno redimible en metálico, los mercaderes pudieron comprar su salvación, expendida por párrocos y frailes.

85 La iglesia de San Miguel se alza junto al portillo de San Miguel, la de San Martín junto al portal de Daroca, la de El Salvador junto al de Guadalaviar, la de San Juan junto al portal de Valencia, y junto a la parroquia de San Esteban se practicó el Portal Nuevo.

86 Incluso las ciudades campamentales islámicas contaban con una mezquita aljama. 
De la mano de la burguesía y del renovado poder de los monarcas y los concejos, la ciudad adquirió un prestigio del que había carecido en la alta Edad Media; el clero secular se recuperó del que había perdido y, entre los regulares, el protagonismo pasó de los monjes dedicados a la explotación de sus dominios rústicos a los frailes que vivían de las limosnas recaudadas en las áreas de depredación, estrictamente delimitadas y cuidadosamente preservadas, de sus conventos urbanos; en ellos, los burgueses enriquecidos encontraban la posibilidad de acometer sus propias fundaciones piadosas, aun en la pequeña escala de la capiIla familiar, y de acceder a ostentosas sepulturas de pago fuera de los fosares parroquiales.

La ciudad real ya no estaba reñida con la ciudad ideal, representada en los monasterios altomedievales. Al dejar de ser en sí misma un lugar despreciable, la ciudad se hizo compleja. En la reforma urbana y en la fundación de nuevas poblaciones irrumpió la estética urbana, tan fuera de lugar antes del siglo XIII; se retomaron los modelos hipodámico, transmitido por Aristóteles, y colonial romano, y el espacio se llenó de contenidos simbólicos como expresión de una comunidad civil armónica sujeta a una diversidad de poderes orgánicamente articulados entre sí: la iglesia, el concejo, las órdenes religiosas, los gremios... Estos poderes produjeron una estructura urbana con distintos centros -religioso (a su vez, parroquial y conventual), mercantil, municipal- sujetos a un orden conjunto que integraba partes heterogéneas.

La estética urbana era selectiva, y en las ciudades mayores se asoció, de modo muy evidente desde el final de la Edad Media, a la segregación social del espacio. Las nuevas instituciones civiles y religiosas, los mercaderes enriquecidos y los nobles que desde la baja Edad Media abandonaban sus residencias rurales para establecerse en las ciudades impulsaron la creación de espacios bellos, acordes con el prestigio que necesitaban escenificar en la etapa de feudalismo de estado -por usar la expresión de Perry Anderson- que se inauguraba. Como la otra cara de la misma moneda, surgieron barrios de pobres, asentamientos improvisados e insalubres donde malvivían, gracias al trabajo precario, la limosna y el delito, los desposeídos que llegaban del campo. Aparecieron también los guetos, donde los concilios de tercero y cuarto de Letrán (I I79 y 1215) decretaron el confinamiento de los habitantes ajenos a la comunidad cristiana -leprosos primero, y judíos, moros y prostitutas más adelante-, como medio de profilaxis y autorreconocimiento para el resto.

La sensibilidad estética de la baja Edad Media -Benevolo ha hablado de un urbanismo góticomostró una evidente preferencia por los trazados regulares y simples, basados en calles rectas y en manzanas rectangulares, que permitían una óptima realización de los aprovechamientos urbanos del suelo, un efectivo control militar de la ciudad y una fiscalidad eficaz. Frente a la extrema sencillez de las ordenaciones románicas, fueron introduciéndose precisas jerarquías urbanas, en las que cada parte ocupaba su sitio adecuado; reaparecieron elementos como las plazas cuadrangulares y las anchas calles porticadas, émulas de los foros, cardos y decumanos del urbanismo romano, y los edificios representativos se vincularon sistemáticamente a espacios libres públicos que les daban un sentido urbano moderno; los palacios de los nuevos patricios urbanos eligieron también situaciones urbanas privilegiadas, beneficiándose de la jerarquía urbana y confirmándola; en la periferia, los conventos mendicantes crearon complejos religiosos y asistenciales, ordenados en torno a vastas plazas de predicación que pasaron a ser los centros simbólicos de los arrabales. A muchas iglesias secundarias se les fue reconocido el rango parroquial, con el consiguiente derecho a celebrar sacramentos, enterrar los muertos del barrio en fosares propios y tocar campanas desde torres erigidas al efecto, que en lo sucesivo protagonizarían el paisaje y el ritmo de la ciudad ${ }^{87}$.

87 Hasta que, en el paso de la Edad Media al Renacimiento, los concejos disputaron a la Iglesia el control del tiempo, tan importante para la burguesía, desde torres de reloj adosadas a los ayuntamientos o exentas, como las de Zaragoza (I504) o Jaca (reloj de I599). 
La mera funcionalidad fue superada por la búsqueda de la belleza. La tendencia general de la sociedad medieval hacia la secularización motivó la recuperación de un simbolismo específicamente civil, ligado a la emergencia del patriciado ciudadano y a la renovación del poder monárquico, y el alejamiento del complejo cuadro de significados simbólicos de orden cósmico-religioso que había determinado la forma de la ciudad altomedieval. Este simbolismo cósmico se había asociado, en términos generales, a formas circulares, basadas en el juego del centro (la iglesia) y el límite (la muralla), mientras que el nuevo simbolismo laico se asociará a la retícula centrada en la cruz de calles del urbanismo romano, referencia idónea tanto para la gran burguesía como para los monarcas absolutos en germinación. Es la misma dicotomía que en el mundo islámico había dado lugar a Bagdag, por una parte, y a 'Anyar, por otra ${ }^{88}$.

El orden indefinido del urbanismo románico, cuyas expresiones más características son la ciudad itinerante y sus posibles evoluciones ad infinitum por manzanas paralelas o en espina de pez, dejó paso a un orden acabado, con un centro y un límite. Con LAVEDAN y HUGUENEY (1974), podemos decir que si en el siglo XIl dominó la villa organizada en función de un camino, la ciudad del siglo XIII se organizó en torno a una plaza.

Si hay un elemento que caracteriza al urbanismo del período que se inicia hacia 1250, es la plaza cívica y mercantil, formalizada arquitectónicamente y no pocas veces bordeada con soportales. Hasta entonces, los mercados se celebraban en explanadas extramuros, inme- diatas pero ajenas al orden del caserío; sólo al final de la Edad Media la ciudad, atraída por él, lo envolvió y civilizó. Los feriales originaron plazas más o menos grandes y despejadas, que generaron nuevos crecimientos extramuros. Así nacieron plazas como la de Cineja (luego la del Mercado) en Zaragoza, la de la Alquibla en Huesca, la de Aínsa, las de Ayerbe, las llamadas de España en Calatayud y en Ejea, la del Mercado de Barbastro, la de La Ginebrosa, la de Cantavieja...

Las plazas de mercado medievales de Cataluña y Aragón solieron rodearse por amplios soportales abiertos por arcos de piedra; en la mayor parte de los casos, se formaron por adición de edificios desiguales, cada uno con uno o más arcos de distinto tipo, pero lograron la unidad por la continuidad espacial del espacio porticado. Todas estas plazas solían tener accesos por las esquinas y planta rectangular o trapezoidal. Según la tesis de GUIDONI (1992), este tipo de plaza era una transposición directa del claustro cisterciense, lo que indica la transmisión al urbanismo de técnicas proyectuales y de diseño propias de la arquitectura, pero también el regreso a la ciudad real, como foro, de la utopía urbana confinada durante la alta Edad Media en los monasterios rurales.

Además de centro de la función mercantil, la plaza del mercado era el lugar público más importante de la ciudad, y pronto fue su centro representativo. La escasez de espacios públicos intramuros hizo de ella un lugar plurifuncional muy apto para funciones colectivas, espectáculos o juegos; la condición cívica de que estaba impregnada la hizo atractiva para las ins-

\footnotetext{
88 No debe pasarse por alto el cambio sustancial en la concepción del espacio que tuvo lugar a mediados del siglo XIII. Como todas las sociedades tradicionales, la Edad Media había imaginado un mundo simbólico, ritualizado, penetrado por lo sagrado, donde el centro podía estar en cada iglesia y el universo compendiado en cada aldea, donde el arriba y el abajo se oponían, del mismo modo que eran esencialmente diferentes el dentro y el fuera, la derecha y la izquierda. Bajo ningún concepto se podía imaginar antes de los siglos XII o XIII un espacio abstracto formado por elementos homogéneos repetibles, a la manera del espacio cartesiano (ZUMTHOR 1993: 5I). Entre los siglos XIII y XVI emergió una nueva concepción cuantitativa y objetivista de la realidad (CROSBY I997: 21), que impulsó la superación de la idea de ciudad como lugar específico e irrepetible, y la de su configuración física como organismo total indivisible. Al tiempo que la sociedad bajomedieval y renacentista se impregnaba de laicismo y la colonización territorial a gran escala exiǵa una técnica urbanística que hiciera posible la creación repetitiva de nuevas poblaciones por efecto de decisiones políticas centralizadas, la parte se emancipó del todo. La ciudad pasó también a ser un agregado de partes racionalmente concebidas, susceptibles de funcionar correctamente en un máximo de situaciones y escalas, y agrupadas según determinadas reglas racionales análogamente tipificadas.
} 
tituciones comunitarias de la ciudad a la hora de elegir su emplazamiento. Las nuevas casas consistoriales, las cárceles y otros edificios representativos, fueron edificándose en torno a estas plazas de mercado que ya podían llamarse con propiedad plazas mayores (la documentación tardomedieval denomina así en ocasiones a la del Mercado de Zaragoza). Este proceso se siguió, entre los siglos XIII y XVI, en Aínsa, Graus, Ejea, Calatayud, etc. En las ciudades de nueva fundación de Levante y la provincia de Teruel, las plazas de mercado constituían desde un principio el centro urbano.

En Aragón y en los secos países mediterráneos -Cataluña, Valencia, Baleares, península itálica-, las plazas mercantiles quedaron normalmente descubiertas, con la única protección de los pórticos adintelados o arcuados con que a veces se rodearon al final del Medievo. En muchas poblaciones de la Corona de Aragón las plazas se completaron con pequeñas lonjas, edificios públicos cubiertos pero abiertos en su frente, destinados a usos mercantiles, contratación de mercancías, operaciones bancarias, etc.; este tipo emparentaba con loggias cubiertas italianas como la de los Lanzi de Florencia o las tardías de los Capitanes, en Vicenza y obra de Palladio, y Rucellai, también en Florencia y obra de Alberti.

La más de las veces se utilizaron como lonjas los porches de la planta baja de las casas consistoriales construidas entre los siglos $X V$ y XVII; es el caso de Bielsa, Cantavieja, Beceite, Calaceite, Valderrobres y tantos otros municipios aragoneses, sobre todo de la zona oriental; en algún caso, como Cantavieja, la teoría de arcos de la lonja se prolonga para conformar una plaza porticada aneja. Otras veces, las lonjas fueron estructuras independientes adosadas a los edificios consistoriales, abiertas por sus frentes como porches exentos; es el caso de las de Alcañiz y Sos.

\section{Desarrollo de la técnica urbanística}

Tanto en las villas nuevas como en las operaciones de ampliación y reforma de las ciudades existentes fue fundamental desde el siglo XIII la recuperación de la antigua herencia de los gromatici romanos, conocida a través de manuscritos y de la práctica arquitectónica monástica, y perfilada por una nueva ciencia topográfica basada en el uso de la cuerda, el compás, la brújula y otros instrumentos ópticos. En la emergencia de un urbanismo de geometría más rigurosa y compleja tuvo un importante papel el trasvase de conocimientos que Occidente absorbió del Islām mediante las traducciones acometidas sistemáticamente en Toledo, Sicilia y Bizancio durante los siglos XII y $X I I I$, que dieron a conocer a los tratadistas griegos y musulmanes, junto a materias enteras antes desconocidas, como la geometría o el álgebra. Si hasta entonces los europeos habían realizado sus replanteos con simples cuerdas anudadas, en adelante se generalizará el uso del astrolabio ${ }^{89}$, instrumento auxiliar de la triangulación que permitía una gran precisión geométrica. A partir de la segunda mitad del siglo XIII, pudo alcanzarse una eficacia sin precedentes en la cartografía y en la realización de trazados urbanos, que permitió la ejecución de alineaciones perfectamente rectas, de orientaciones cardinales exactas y de ordenaciones ortogonales de gran pureza.

La apabullante aportación de conocimientos novedosos que sacudió Occidente en este periodo cristalizó en el nacimiento de la arquitectura y la ingeniería como actividades intelectuales emancipadas de la construcción. Los técnicos encargados del planeamiento urbano y territorial, como otros especialistas medievales, debieron de trabajar con una gran movilidad en el territorio de la Europa occidental, lo que explica la homogeneidad de las técnicas, la difusión de los modelos y la profunda unidad de la experiencia urbanística europea.

89 Instrumento de origen árabe al que habían dedicado tratados los astrónomos andalusíes Maslama de Madrid (m. ca. 1007) e lbn al-Ṣaffär (m. 1035), y cuyo conocimiento fue divulgado en Europa por el gran intelectual benedictino francés Gerberto de Aurillac (papa Silvestre II desde el 999), que lo había conocido en el monasterio de Ripoll entre el 967 y el 969. Alfonso X describió el manejo del astrolabio plano y el esférico en los Libros del saber de Astronomía (1280). 
En Aragón, conservamos documentación escrita del siglo XIII relativa a la actuación de los quiñoneros, personajes que podrían equipararse a los futuros urbanistas, y cuyo papel era estrictamente técnico, bajo una directa supervisión de la autoridad. Correspondía al quiñonero amojonar el término, elegir el lugar o los lugares donde fuera conveniente erigir las pueblas, parcelar el suelo urbano para su posterior construcción, deslindar el suelo cultivable en fincas para los pobladores y organizar todo lo relativo a pastos, aguas, vías, comunicaciones territoriales, etc. Desempeñaba, por tanto, una inequívoca labor de planificación integral del territorio, regida por criterios complejos, funcionales pero también formales: el nombramiento de quiñoneros para Mosqueruela, Camarena, Valdelinares, Peña Calva, Atorela, Turriles y Salmansa, de 1262, establecía que se elegirían para la ubicación de las pueblas aquellos lugares «do a vos fuere mellor visto e mas conveniente».

\section{Algunos ejemplos del urbanismo gótico aragonés}

En la actual provincia de Teruel y, cuando se fundó (1202), fronteriza con al-Andalus, Manzanera es un precoz ejemplo aragonés de fundación ordenada según unos criterios urbanísticos novedosos, con un trazado casi hipodámico. Bordeando una meseta, adopta la forma de un rectángulo alargado, con un perímetro amurallado de lados rectos y paralelos y ángulos achaflanados. Las casas se agrupan en pequeñas manzanas cuadradas, separadas por una cuadrícula de calles rectas, de las que las centrales longitudinal y transversal unían las cuatro puertas de la muralla y forman en el punto de cruce una plaza, a la que recaen la iglesia del Salvador y el ayuntamiento.

Como en algunas bastidas francesas contemporáneas (burgo nuevo de Carcasona, Mirande), la forma cuadrada de las manzanas de Manzanera sólo persigue una apariencia de bidireccionalidad, ya que la forma y agrupación de las parcelas estrechas y profundas sigue haciendo que las calles de una dirección den acceso a las viviendas y las perpendiculares correspondan a testeros.
Aunque limitado a un ensanche de la ciudad y sin espacios libres, edificios públicos ni complejidad alguna, el sector norte del ensanche de los Almudines Viejos en Alcañiz (siglo XIV) también presenta un inequívoco trazado tardomedieval de manzanas casi perfectamente cuadradas separadas por una trama ortogonal de calles e integradas por parcelas estrechas y profundas orientadas indistintamente a cualquiera de las direcciones.

Alcorisa (comienzos del siglo XIII) representa el tipo de ciudad regular más extendido en Aragón durante este período, caracterizado por su sencillez y por la falta de jerarquía espacial, así como por la ausencia de plaza u otros elementos singulares representativos. Su trazado es muy regular, con calles ortogonales paralelas y manzanas alargadas formadas por la alineación simple de parcelas estrechas y profundas; las calles que dan acceso a las parcelas parten, en espina de pez, de los dos lados del eje principal, y las manzanas así delimitadas se extienden sin interrupción hasta los límites del recinto. Es una típica bastida en llano, rodeada por una muralla, desaparecida, que debió de tener seis puertas; la puerta meridional se abría hacia un altozano coronado por la iglesia parroquial de santa María la Mayor. La ausencia de plazas o espacios de desahogo dentro de la cerca revela como objetivo básico del plan conseguir la mayor densidad con una parcelación exclusivamente residencial, ya que la propia iglesia se emplaza fuera del recinto.

El modelo de Alcorisa, que aúna fuertes condicionantes defensivos con una ordenación regular, reaparece en Muniesa, La Ginebrosa, Fuentespalda, Mosqueruela, Villafranca del Campo, Cantavieja o La Puebla de Valverde (Teruel); fuera de Aragón fue también un esquema muy habitual, repetido en fundaciones vizcaínas (Bilbao, Guernica), guipuzcoanas (Guetaria, Fuenterrabía), italianas (Villanova d'Asti) y francesas (Montastruc-la-Conseillère, Montesquieu-Volvestre, Le-Plan-Volvestre) de los siglos XIII y XIV.

Cuando la población era de menor tamaño, la espina de pez podía reducirse hasta una elemental cruz de calles delimitadora de cua- 
tro manzanas residenciales, como ocurría en Valbona (Teruel) o en Santa Cilia de Jaca (Huesca); el mismo esquema debió de presentar el núcleo originario de La Ginebrosa (Teruel), anterior a la ampliación de 1291. En estos casos, el edificio religioso quedaba siempre fuera del caserío y separado de él.

En La Ginebrosa, la ampliación de |29| supuso la construcción de una nueva cerca que incorporó la iglesia a una de sus esquinas y convirtió la plaza del mercado, situada ante la puerta, en plaza intramuros, con la consiguiente formalización geométrica. Procesos análogos tuvieron lugar en Cantavieja, Mora de Rubielos y otras muchas poblaciones.

Aunque Santa Cilia de Jaca ya existía en el siglo $X$, el trazado que conocemos debe de ser contemporáneo de la carta de población dada en 1336 por el monasterio de San Juan de la Peña. La precisa ortogonalidad de sus calles, la modulación de sus manzanas y la forma cuadrada de éstas recuerda algunas fundaciones militares turolenses y francesas de los siglos XIII y XIV. Su planta sugiere un crecimiento en dos fases: la primera correspondería a una planta ideal que reprodujo un claustro o un campamento romano reducido, con dos calles en cruz y cuatro manzanas cuadradas, rodeadas por una franja continua de parcelas que, seguramente, contaría con traseras fortificadas o se acomodaría a una cerca perimetral. Más tarde, con una parcelación muy diferente, este núcleo se desbordó hacia el oeste.

El mejor ejemplo aragonés de las nuevas concepciones urbanísticas es Mosqueruela (1262), asentamiento en llano de perímetro rectangular cuyo centro es una plaza, coincidente con el cruce de las dos calles principales y trazada con una proporción 3:4, idéntica a la del perímetro murado. A los lados de la plaza se enfrentan la iglesia de la Asunción y el ayuntamiento; el lado sur de la plaza está porticado gracias a los ocho arcos de la casa consistorial, y el oriental también, en continuidad con el porticado del lado este de la calle Mayor, que la atraviesa por este costado y sigue hasta dos puertas de la muralla: la puerta-capilla de San Roque, al norte, y un portal desaparecido al sur.
La influencia romana no sólo subyace en el manifiesto parentesco de la planta con los campamentos y las ciudades coloniales, sino en la idea rectora que subordina la posición de la iglesia, las instituciones civiles y la edificación privada a la ordenación jerárquica del espacio público: la plaza ha desplazado a la iglesia del centro urbano, preludiando la vocación civil de la ciudad renacentista.

Debe llamarse la atención sobre la forma de la plaza central, que ya no es el resultado de vaciar una de las manzanas, sino que responde -en Mosqueruela sólo en una de las dos direcciones- al modelo de plaza centrada en el cruce de dos calles ortogonales principales, a la manera de las colonias romanas, las fundaciones altomedievales anglosajonas o algunas pueblas bajomedievales del Piamonte y el Véneto, y del Levante español (más tardías), como Castelfranco Veneto (I | 89), Cittadella (Véneto, 1220) o Villarreal de Burriana.

A diferencia de la plaza con acceso por las esquinas, ésta es compatible con el mantenimiento de un viario jerarquizado con un cardo y un decumano máximos formando una cruz de calles, a cambio de insertarse de forma menos natural en la trama viaria, al interrumpir las calles y generar en la plaza un tráfico de paso por sus ejes; obliga, además, a disponer manzanas singulares en forma de $L$.

\section{LA EXPANSIÓN DEL URBANISMO REGULAR EN LA CORONA DE ARAGÓN}

La planificación urbana aragonesa sigue ya en el siglo XIII métodos sistemáticos, produciendo resultados cada vez más generalizables y cada vez más lejanos de una simple parcelación del suelo urbano: la ciudad se adentra en la categoría del fenómeno estético.

En Aragón sólo aparecen muestras de planificación avanzada en la actual provincia de Teruel, el único territorio que aún se estaba colonizando en ese tiempo; después de 1262, será rara la aparición de nuevas fundaciones urbanas en el reino, y habrá que mirar a Valencia 
o a Mallorca para estudiar la evolución subsiguiente de las técnicas urbanísticas nacidas y perfeccionadas en el norte subpirenaico.

\section{Poblaciones de la Plana de Castellón}

En la Plana de Castellón, los aragoneses fundaron en el siglo XIII, mediante fueros derivados de los de Zaragoza, Daroca o Aragón, un grupo de ciudades que se cuentan entre los más altos ejemplos de la planificación medieval europea. Las plantas de Soneja (1245), Almenara (1248), Castellón (I25I), Villarreal (1272) o Nules (principios del siglo XIV) muestran una clara continuidad en los métodos planificadores que se habían ido formando en Aragón desde el siglo Xl y que habían alcanzado resultados próximos en las fundaciones realizadas en el siglo XIII al sur de la provincia de Teruel, con ordenamientos jurídicos muy parecidos.

Entre todas estas fundaciones castellonenses destaca Villarreal, comenzada a edificar en 1272 y dotada con los fueros de Aragón en 1274. Su planta es una realización con mayor precisión geométrica del modelo que se había ejecutado en Mosqueruela, ante la que resulta ya inevitable recordar el trazado de la ciudad colonial romana, con su cardo y su decumano máximos, y el foro porticado en la intersección de los dos ejes. Se trata de un rectángulo perfecto, de proporción 3:5 entre sus lados ${ }^{90}$, delimitado por una muralla con cubos cilíndricos en los ángulos y una puerta en el centro de cada uno de los cuatro paños, unidas entre sí por dos calles principales en cruz, en cuyo centro se forma la plaza, cuadrada y con las esquinas cerradas, como en los modelos piamonteses y venecianos realizados desde finales del siglo XIl; a cada lado de las calles principales corre de extremo a extremo otra secundaria, delimitando manzanas perfectamente rectangulares. Tanto la plaza central como las dos calles principales contaron con soportales; a la plaza se abría la casa consistorial, pero no la iglesia, que, como en otros muchos modelos peninsulares, se construyó junto a una de las puertas de la muralla, reforzándola y dignificándola.

\section{Las Ordenaciones de Mallorca}

Más tarde vinieron los modelos teóricos, únicos en el Medievo europeo, de las Ordenaciones de Jaime II para las nuevas pueblas en el reino de Mallorca, y de la descripción de la ciudad ideal del valenciano Eximeniç.

Las Ordinacions de Jaime II, promulgadas en el año 1300, ordenaban que las nuevas pueblas establecidas para colonizar el territorio fueran trazadas por un «ordonador» O «stablidor»» que habría de seguir unas normas urbanísticas precisamente reguladas. Estamos ante la primera propuesta escrita de una ciudad ordenada por sucesiva partición de un cuadrado perfecto, y también ante un verdadero programa de planificación y colonización territorial a partir de esas nuevas ciudades.

Cada puebla se destinaba a una población formada por cien familias de agricultores, a cada una de los cuales se le adjudicaban dos parcelas, una intramuros, de un cuartón de superficie - $1.775 \mathrm{~m}^{2}$-, y otra agrícola, de cinco cuarteradas -3'55 hectáreas-, además de otras diez cuarteradas $-7^{\prime} 10$ hectáreas- de pastos para el ganado. Consecuentemente, el campo periurbano se parcelaba con criterios geométricos que prolongaban los utilizados en el recinto urbano.

La ciudad de las Ordenaciones tiene una estructura elemental, que puede reproducirse en llano cuantas veces sea necesario. Su perímetro es un cuadrado de unos 450 metros de lado, en el que se contienen 16 (4 por 4) manzanas cuadradas de unos 84 metros de lado,

\footnotetext{
90 La misma proporción que los perímetros amurallados de Almenara y Nules, también en Castellón, o que las francesas Aigues-Mortes (1246) y Monpazier (1284). La frecuencia con que perímetros urbanos, plazas y manzanas de fundaciones de este período se atienen a proporciones elementales como esta 3:5, 3:4 o I:I acredita el manejo de sistemas geométricos carentes de contenido funcional e inspirados por una voluntad estética.
} 
rodeadas por una franja perimetral de semimanzanas de 84 por 42 metros con cuartos de 42 por 42 en las esquinas; cada manzana cuadrada se subdivide en cuatro parcelas igualmente cuadradas de un cuartón de superficie (42 por 42 metros). Hay, pues, cien parcelas en total, ordenadas en $[1 / 2+4+1 / 2]^{2}$ manzanas. Las calles son rectas $y$ forman una cuadrícula; su anchura, constante, es fijada por las Ordenaciones en un destre y medio (6'32 metros).

El modelo de las Ordenaciones se materializó con la mayor exactitud en las fundaciones mallorquinas regulares de Lluchmajor, Felanitx y, sobre todo, Petra y Sa Pobla. Por su uso exhaustivo del cuadrado, son un precedente muy directo de la ciudad de Eximeniç y de las fundaciones españolas en América, pero falta en ellas la idea de jerarquía y cualificación espacial que estaba en Mosqueruela o en Castellón, y que repetirán esos modelos posteriores; es todavía un modelo regido por la homogeneidad, cuya misión fundamental es la garantía de igualdad de los pobladores.

\section{La ciudad ideal de Françesch Eximeniç}

A finales del siglo XIV, se escribió, también en el ámbito político de la Corona de Aragón, la primera teoría urbanística formulada en Occidente desde la Antigüedad. El franciscano valenciano Françesch Eximeniç, consejero de Pedro IV (1334- |387), describió, en el libro XII del Crestiá (| 384-1386), una ciudad utópica que representaba bien el ideal urbano bajmedieval: una «ciutat bella e bé edificada» concebida como conjunto armónico y, por tanto, lógico e inteligible.

La ciudad eximeniana es la culminación de una nueva idea de la creación artificial enunciada por la escolástica tomista, sustancialmen- te distinta de la agustiniana que había dominado hasta el siglo XIII. La obra artificial ya no se agota en un valor simbólico ${ }^{91}$, ni puede aplicarse el principio de la concordancia de opuestos para afirmar que la belleza del conjunto requiera la fealdad de sus partes inferiores. Revolucionariamente, se concibe la posibilidad de una obra de arte específicamente bella, por su cualidad material y no por lo que representa, formada por partes análogamente bellas: no basta con la belleza de unos cuantos edificios privilegiados inmersos en un caserío cochambroso; la perfección del conjunto exige la belleza homóloga de todas sus partes. La ciudad de Eximeniç es la propuesta teórica medieval más acabada de una ciudad orgánicamente bella, concebida ya, como lo hará el Renacimiento, como un cuerpo entero y bien acabado -perfecto- de partes bellas, dispuestas de tal modo que ninguna pueda cambiarse, quitarse ni añadirse, de acuerdo con la máxima aristotélica que retomará Leon Battista Alberti.

Para ser perfecta, la ciudad debe asentarse en llano ${ }^{92}$ y lograr el perfecto acuerdo entre la forma social y la material: «La ciudad -escribe Eximeniç en el capiítulo XCVIII- debe estar bien compuesta, esto es, bien ordenada en tres aspectos: el primero es que esté bien arreglada en lo espiritual; el segundo, que esté gobernada por una buena ley temporal, y el tercero que esté bien edificada en su forma material.»>

Como en la Jerusalén Celeste, en la muralla cuadrada de la ciudad ideal de Eximeniç hay doce puertas, tres en cada lado. El conjunto se configura a partir de dos ejes principales ortogonales y orientados hacia los puntos cardinales, que al cruzarse en una plaza central dividen el recinto cuadrado en cuatro cuarteles, cada uno con una plaza secundaria propia y destinado a un tipo diferente de habitantes; paralelas a esos ejes, corren cuatro calles secunda-

91 Lo que no excluye que la ciudad de Eximeniç tenga mucho de teocrática, con una plaza central dominada por la catedral, el palacio episcopal y las casas sacerdotales, y cuatro plazas de barrio presididas por otras tantas iglesias parroquiales.

92 «Los grandes filósofos dictan los siguientes puntos. Lo primero, que es propio del sitio de la ciudad, es que sea llana, puesto que así es más fácil ampliarla y ensancharla» (Dotzen libre del Crestiá CVI). 
rias en cada dirección, que dividen cada cuartel en dieciséis manzanas de 82 metros de lado, divididas en cuatro solares de 4 I por 4 I metros.

Cada uno de los cuatro barrios en que queda dividido el recinto urbano constituye algo parecido a una pequeña ciudad dotada de todo lo preciso para que sea posible en él una vida autosuficiente: un almudí, un convento mendicante, una parroquia y una plaza que le sirve de centro particular, además de todos los oficios necesarios para su funcionamiento autónomo: carniceros, pescateros, labradores, comerciantes... De este modo, la nueva ciudad no se reparte en barrios diferenciados, como la contemporánea ciudad gremial, sino que materializa el principio tomista del cuerpo perfecto compuesto por partes perfectas.

El esquema eximeniano comprende al mismo tiempo la experiencia del campamento y la ciudad de fundación romana, la ciudad ideal apocalíptica y lo visto en las ciudades aragonesas de Levante y en Mallorca, cuyas pueblas tienen dimensiones de solares y manzanas casi iguales.

Eximeniç fue la culminación del camino iniciado en Mosqueruela y proseguido en Levante $y$ en Mallorca durante los siglos XIII y XIV, $y$, a través de él, esos modelos estuvieron en la base de la ciudad colonial hispanoamericana, muestra inagotable de los mejores y más ambiciosos ejemplos de ciudades ordenadas del Renacimiento y, como ha escrito Fernando de Terán, la más grande empresa de creación de ciudades llevada a cabo por un pueblo en toda la historia.

\section{BIBLIOGRAFÍA}

ACIÉN ALMANSA, Manuel (200 I): «La formación del tejido urbano en al-Andalus»); en La ciudad medieval: de la casa al tejido urbano, pp. | |-32. Universidad de CastillaLa Mancha; Cuenca.

ACIÉN ALMANSA, M. y VALLEJO TRIANO, A. (1998): «Urbanismo y Estado islámico: de Corduba a Qurtuba-Madinat al-Zahrā»;; Genèse de la ville islamique en al-Andalus et au Maghreb occidental, pp. 107-136. Casa de VelázquezConsejo Superior de Investigaciones Científicas; Madrid.
ALOMAR ESTEVE, Gabriel (1976): Urbanismo regional en la Edad Media: las "Ordinacions" de Jaime II (1 300) en el reino de Mallorca. Gustavo Gili; Barcelona.

BETRAN ABADÍA, Ramón (1992): La forma de la ciudad. Las ciudades de Aragón en la Edad Media. Colegio Oficial de Arquitectos de Aragón. Zaragoza.

BETRAN ABADÍA, Ramón (1996): «Mutación y permanencia: el plano de Zaragoza en la Edad Media»; Tecnología y sociedad: las grandes obras públicas en la Europa medieval, pp. 38I-433. Gobierno de Navarra; Pamplona.

BETRAN ABADÍA, Ramón (1999a): El Camino de Santiago y la ciudad ordenada en Aragón. Gobierno de Aragón; Zaragoza.

BETRAN ABADÍA, Ramón (1999b): «El casco histórico de Jaca»; Centros históricos aragoneses, pp. 83-I I4. Institución Fernando el Católico; Zaragoza.

BETRAN ABADÍA, Ramón (2005): «Continuidad, proyecto y evolución urbana en Saraqusța (7|4- | | | 8)»; Zaragoza. Espacio histórico. Ayuntamiento de Zaragoza; Zaragoza (en prensa).

BOIS, Guy (1989): La revolución del año mil. Lournand, aldea del Mâconnais, de la Antigüedad al feudalismo. Crítica; Barcelona, 20002.

BONASSIE, Pierre (198I): Vocabulario básico de la historia medieval. Crítica; Barcelona, 19995.

BRUNSCHVIG, Robert (1947): «Urbanisme médieval et droit musulman»; Revue des Études Islamiques XV, pp. |27-155.

CANIGGIA, Gianfranco (1973): «Lectura de las preexistencias antiguas en los tejidos urbanos medievales»; Análisis urbano. Textos, pp. 27-60. Instituto Universitario de Ciencias de la Construcción; Sevilla, 1997.

CROSBY, Alfred W. (1997): La medida de la realidad. La cuantificación y la sociedad occidental, 1250- I600. Crítica; Barcelona, 1998.

DOMÍNGUEZ ORTIZ, A. y VINCENT, V. (1978): Historia de los moriscos. Vida y tragedia de una minoría. Alianza; Madrid, 1985.

DUBY, Georges (1962): Economía rural y vida campesina en el Occidente medieval. Ediciones Altaya; Barcelona, 1999.

ELIADE, Mircea (1957): Lo sagrado y lo profano. Paidós; Barcelona, 1998.

GARCÍA DE VALDEAVELLANO, Luis (1969): Orígenes de la burguesía en la España medieval. Espasa-Calpe; Madrid.

GARCÍA-BELLIDO Y GARCÍA DE DIEGO, Javier ( 1997): «Principios y reglas morfogenéticas de la ciudad islámica»; Qurtuba 2, pp. 59-86.

GARCÍA-BELLIDO Y GARCÍA DE DIEGO, Javier (200 I): «Morfogénesis de la ciudad islámica: algunas cuestiones abiertas y ciertas propuestas explicativas»; L'urbanisme 
dans l'Occident musulman au Moyen Âge. Aspects juridiques; pp. 243-283. Casa de Velázquez-Consejo Superior de Investigaciones Científicas; Madrid.

GEREMEK, Bronislaw (1986): La piedad y la horca. Historia de la miseria y de la caridad en Europa. Alianza; Madrid, 1989.

GRABAR, Oleg (1973): La formación del arte islámico. Cátedra; Madrid. 1979.

LA GRANJA, Fernando de (1966): La Marca Superior en la obra de al-'Udri. Heraldo de Aragón; Zaragoza.

GUICHARD, Pierre et alii (1985): «Las Españas medievales: pluralidad de destinos»;; Historia de los españoles I, pp. II-353. Crítica; Barcelona, 1989.

GUIDONI, Enrico (1978a): La ville européene. Formation et signification du quatrième au oncième siècle. Pierre Mardaga; Bruselas, 1981.

GUIDONI, Enrico (1978b): «Strada e isolato. Dall'Alto Medioevo al Settecento»; Lotus International 19, pp. 4-19. Milán.

GUIDONI, Enrico (1989): Storia dell'urbanistica. II Duecento. Editori Laterza; Bari.

GUTIÉRREZ GONZÁLEZ, Francisco Javier (2002): Informe preliminar de resultados de la excavación arqueológica realizada en el vial tramo central del paseo de la Independencia de Zaragoza. Inédito.

HEERS, Jacques (1990): La ville au Moyen Âge en Occident. Paysages, pouvoirs et conflits. París.

AL-HIMYARI: Kitâb ar-rawd al-Mictâr. Anúbar; Valencia, 1963.

IBN JALDUN (1977): Introducción a la historia universal (alMuqaddimah). Fondo de Cultura Económica; México D.F.

JIMÉNEZ, P. y NAVARRO, J. (200I): «El urbanismo islámico y su transformación después de la conquista cristiana: el caso de Murcia»; La ciudad medieval: de la casa al tejido urbano, pp. 7I-129. Universidad de Castilla-La Mancha; Cuenca.

LACARRA DE MIGUEL, José María (1950): El desarrollo urbano de las ciudades de Navarra y Aragón en la Edad Media. Diputación General de Aragón; Zaragoza, 1991.

LACARRA DE MIGUEL, José María ( 198 I): Colonización, parias, repoblación y otros escritos. Institución Fernando el Católico; Zaragoza.

LACARRA DE MIGUEL, José María ( 1982-1985): Documentos para el estudio de la reconquista y repoblación del valle del Ebro (2 vol.) Anúbar; Zaragoza.

LAPEÑA PAUL, Ana Isabel (1994): «La presencia del monasterio de San Juan de la Peña en la ciudad de Jaca»; Actas del Congreso de historia de la Corona de Aragón III: Jaca en la Corona de Aragón (siglos XII-XVIII), pp. 305-3I 4. Gobierno de Aragón; Zaragoza.
LAURENT, A., MALEBRANCHE, R. y SERAPHIN, G. (1988): Bastides. Villes Nouvelles du Moyen-Age. Éditions Milan; Toulouse.

LAVEDAN, P. y HUGUENEY, J. (1974): L'Urbanisme au Moyen Age. Droz; Ginebra.

LEDESMA RUBIO, María Luisa (1992): Cartas de población aragonesas en la Edad Media. Institución Fernando el Católico; Zaragoza.

LINAZASORO, José lgnacio (1978): Permanencias y arquitectura urbana. Las ciudades vascas de la época romana a la llustración. Gustavo Gili; Barcelona.

LÓPEZ CUERVO, Serafín (1983): Medina az-Zahra. Ingeniería y formas. Ministerio de Obras Públicas y Urbanismo; Madrid.

MAílLO SALGADO, Felipe (1996): «El palacio islámico: de la Dār al-Imāra a la ciudad palatina»; Tecnología y sociedad: las grandes obras públicas en la Europa medieval, pp. 327-362. Gobierno de Navarra; Pamplona.

MUMFORD, Lewis (|96|): La ciudad en la historia (2 vol.). Ediciones Infinito; Buenos Aires, 19792.

MÜNZER, Jerónimo (| 495): Viaje por España y Portugal. Ediciones Polifemo. Madrid; 1991.

MUÑOZ Y ROMERO, Tomás ( 1847): Colección de Fueros Municipales y Cartas Pueblas. Atlas; Madrid, 1978.

NAVARRO, J. y JIMÉNEZ, P. (2003): «Sobre la ciudad islámica y su evolución»; Estudios de arqueología dedicados a la profesora Ana María Muñoz Amilibia, pp. 319-38I. Universidad de Murcia; Murcia.

PASSINI, Jean (1988): Aragón. Los núcleos urbanos del Camino de Santiago. Diputación General de Aragón; Zaragoza.

PICCINATO, Luigi (1978): Urbanistica medievale. Edizioni Dedalo; Bari.

PINON, Pierre (200I): «La transición desde la ciudad antigua a la ciudad medieval: permanencia y transformación de los tejidos urbanos en el Mediterráneo Oriental»; La ciudad medieval: de la casa al tejido urbano, pp. 179-213. Universidad de Castilla-La Mancha; Cuenca.

SANGORRÍN Y DIEST-GARCÉS, Dámaso (1920): El libro de la Cadena del Concejo de Jaca. Documentos reales, episcopales y municipales de los siglos X, XI, XII, XIII y XIV. Casino de Jaca/Heraldo de Aragón; Zaragoza, 1979.

VAN STAËVEL, Jean-Pierre (1995): «Casa, calle y vecindad en la documentación jurídica»; Casas y palacios de al-Andalus. Siglos XII-XIII, pp. 53-6I. Sierra Nevada 95; Barcelona-Madrid.

VAN STAËVEL, Jean-Pierre (200I): «Le qāḍī au bout du labyrinthe: l'impasse dans la littérature jurispudentielle mâlikite (al-Andalus et Magreb, 3e/lXe - 9e/XVe s.)»; L'urbanisme dans l'Occident musulman au Moyen Âge. Aspects juridiques; pp. 39-63. Casa de Velázquez-Consejo Superior de Investigaciones Científicas; Madrid. 
TORRES BALBÁS, Leopoldo (197I): Ciudades hispanomusulmanas. Ministerio de Asuntos Exteriores; Madrid, 1985.

TORRÓ ABAD, Josep (1996): «El urbanismo mudéjar como forma de resistencia. Alquerías y morerías en el reino de Valencia (siglos XIII-XV)»; Actas del VI Simposio Internacional de Mudejarismo (Teruel. 16-18 de septiembre de 1993), pp. 535-598. Instituto de Estudios Turolenses; Zaragoza.

UBIETO ARTETA, Antonio (1952): «Ayerbe: notas y sugerencias»; Argensola 9; pp. I- I0. Instituto de Estudios Oscenses; Huesca.
VALLIN, Pierre (1984): «Genèse médiévale des villes d'Occident: Points de vue d'histoire sociale et de théologie»; Lídée de la ville. Actes du colloque international de Lyon, pp. 65-84. Editions du Champ Vallon; Seyssel.

VILA, Soledad (1984): La ciudad de Eiximenis. Un proyecto teórico de urbanismo en el siglo XIV. Valencia.

ZUMTHOR, Paul (1993): La medida del mundo. Representación del espacio en la Edad Media. Cátedra; Madrid, 1994. 


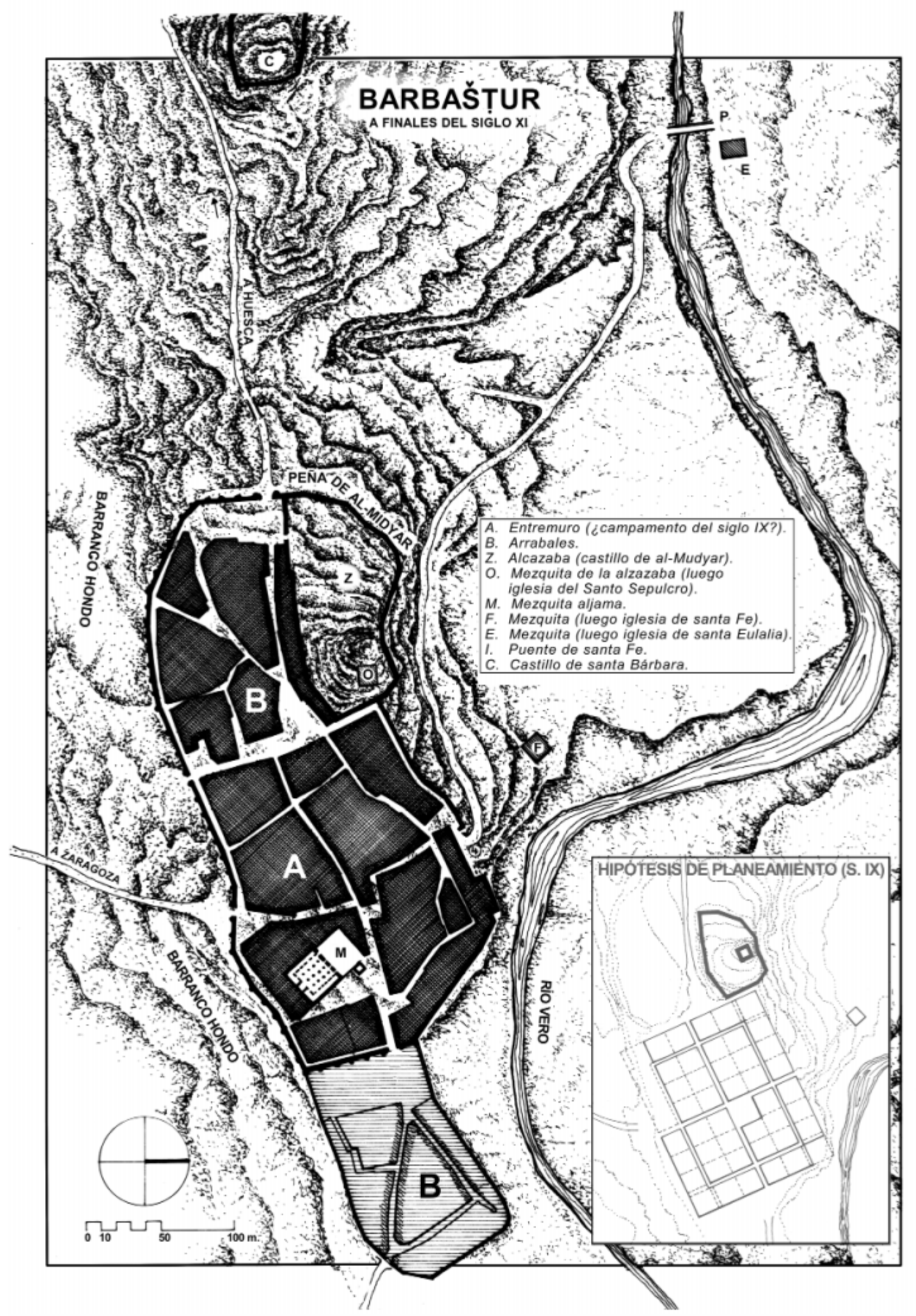

Lam. I. Organización y regularidad en la ciudad islámica. Barbašțur 


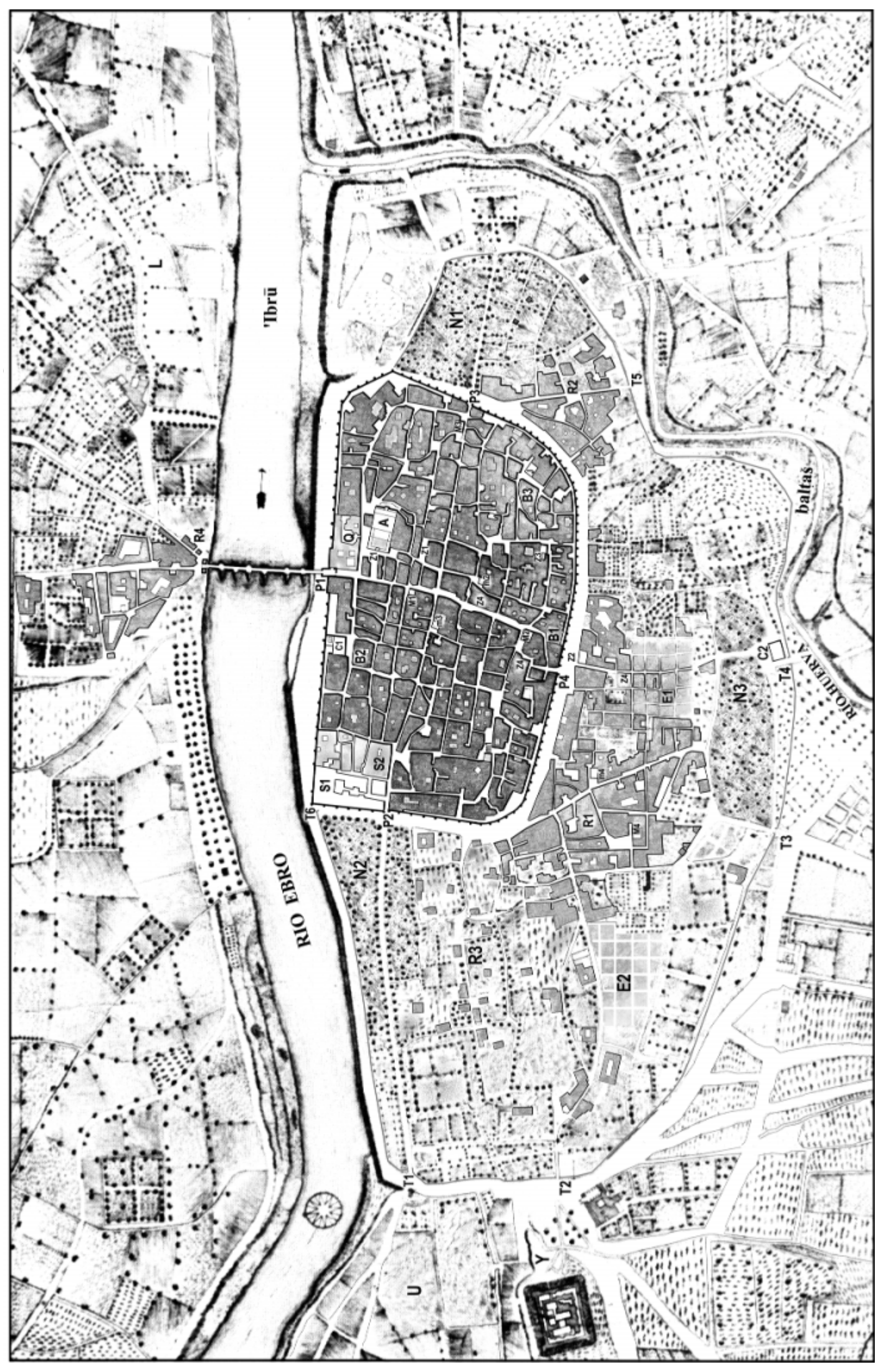

Lam. 2. Organización y regularidad en la ciudad islámica. Saraqusta en el siglo XI 


\section{LEYENDA Lámina 22}

P MURALLA DE PIEDRA (S. III):

PI puerta del Puente ( $b^{a} b$ al-Qandara)

P2 puerta de Toledo ( $b^{a} b$ Eulaydula)

P3 puerta de La Meca (b b al-Qibla $)$

P4 arco Cinegio (bab al-Sinh $\left.{ }^{a} \ddot{y} a\right)$

A MEZQUITA ALJAMA (AL-ŸaMIC)

M MEZQUITAS MENORES
MI futura iglesia de Santiago (doc. I I |8)
M2 futura iglesia de San Gil (doc. | | 21 )
M3 futura iglesia de la Magdalena (doc. I I26)
M4 futura mezquita vieja de la morería

m OTRAS POSIBLES MEZQUITAS MENORES

mI futura iglesia de San Felipe (doc. I|4I)

m2 futura iglesia de San Juan el Viejo (doc. I I55)

m3 futura iglesia de Santa Cruz (doc. I I56)

m4 futura mezquita mayor de la morería

S ALCAZABA (AL-QAIABA; AL-SUDDA)

SI área incluida en el recinto con seguridad

S2 área posiblemente incluida en el recinto

Q ¿ALCAZAR ANTIGUO? (DOC. 937)

C IGLESIAS MOZARABES
CI Santa María la Mayor
C2 Santas Masas

J SINAGOGA

Z AREAS COMERCIALES
ZI zocos centrales
Z2 zoco de la puerta de Sinhacha
Z3 alcaicería (al-qays ${ }^{2}$ riyya)
Z4 tiendas

B BARRIOS INTRAMUROS
BI barrio de Sinhacha ( ${ }^{a}$ rat al-Sinh $\left.{ }^{a} \ddot{y} a\right)$ (posible localización en el siglo VIII)
B2 mozarabía en el siglo Xl
B3 Judería (madlnat al-yahñd; ${ }^{a}$ rat al-yahñd)

R ARRABALES ANTERIORES AL SIGLO XI

RI arrabal de Azoque (raba? al-Sñq)

R2 arrabal ¿de Curtidores? (raba? al-Dabbäỳ̀n)

R3 arrabal de Alfareros (raba? al-Faÿarln)

R4 arrabal de Atabahas, llamado el Arrabal (ar-Raba?)

E ARRABALES TAIFALES (SIGLO XI) (reconstrucción imaginaria)

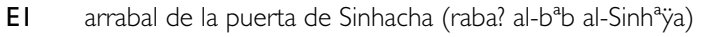

E2 arrabal del Campo del Toro

Y LA ALFAJERIA (AL-ÕACFARIYYA)

$\cup \quad$ ALMOZARA (AL-MUI'RA)

$N$ NECROPOLIS

NI cementerio de la puerta de La Meca (maqbarat al-bab al-Qibla)

N2 cementerio de la puerta de Toledo (maqbarat al-bab Eulaydula)

N3 cementerio de la puerta de la serpiente (maqbarat $b^{a} b$ al- anaë)

T MURO DE TIERRA (RADAM) (trazado hipotético)

TI puerta de Sancho (denominación posterior; doc. I 180)

T2 Portillo

T3 puerta del Huerva (bab al-Baldaë) (doc. 1259)

T4 ¿Puerta de la Serpiente? ( $b^{a} b$ al- anaë)

T5 Puerta Quemada (denominación posterior)

T6 Puerta del mercado (denominación posterior)

L ALMUNIAS 


\section{REALIZACIONES URBANAS EN LA ZARAGOZA TAIFAL}

A

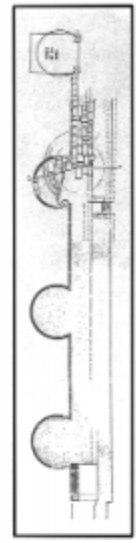

B

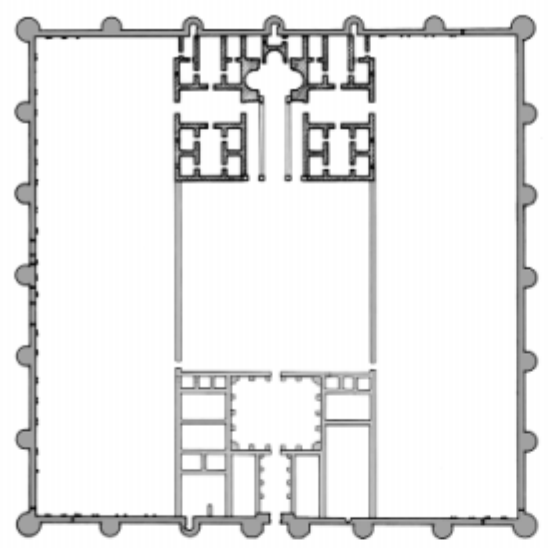

C

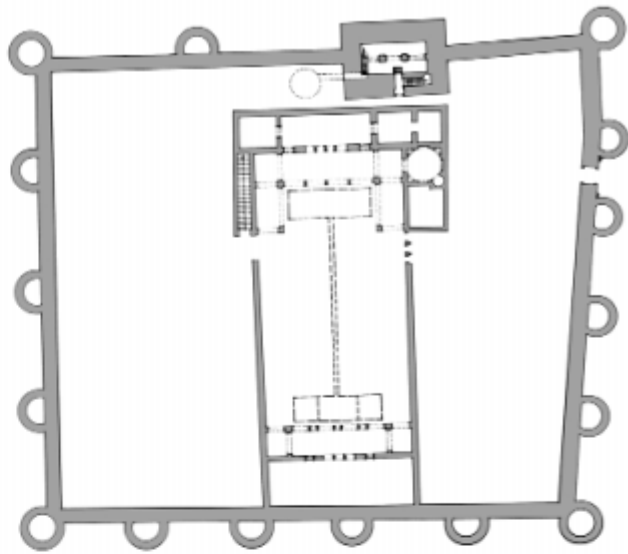

A la muralla romana en san Juan de Los Panetes, SEgún Francisco iÑIGUeZ

B QASTR AL-MŠATTA (JORDANIA, 743-744), SEGÚN OLEG GRABAR

C LA ALJAFERIA DE AL-MUQTADIR, SEgÚN CHRISTIAN EWERT

MUROS SUPUESTOS

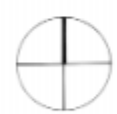

MUROS EXCAVADOS

$$
\text { DrADR, SEGÜN CHRSTIAN EWERT }
$$




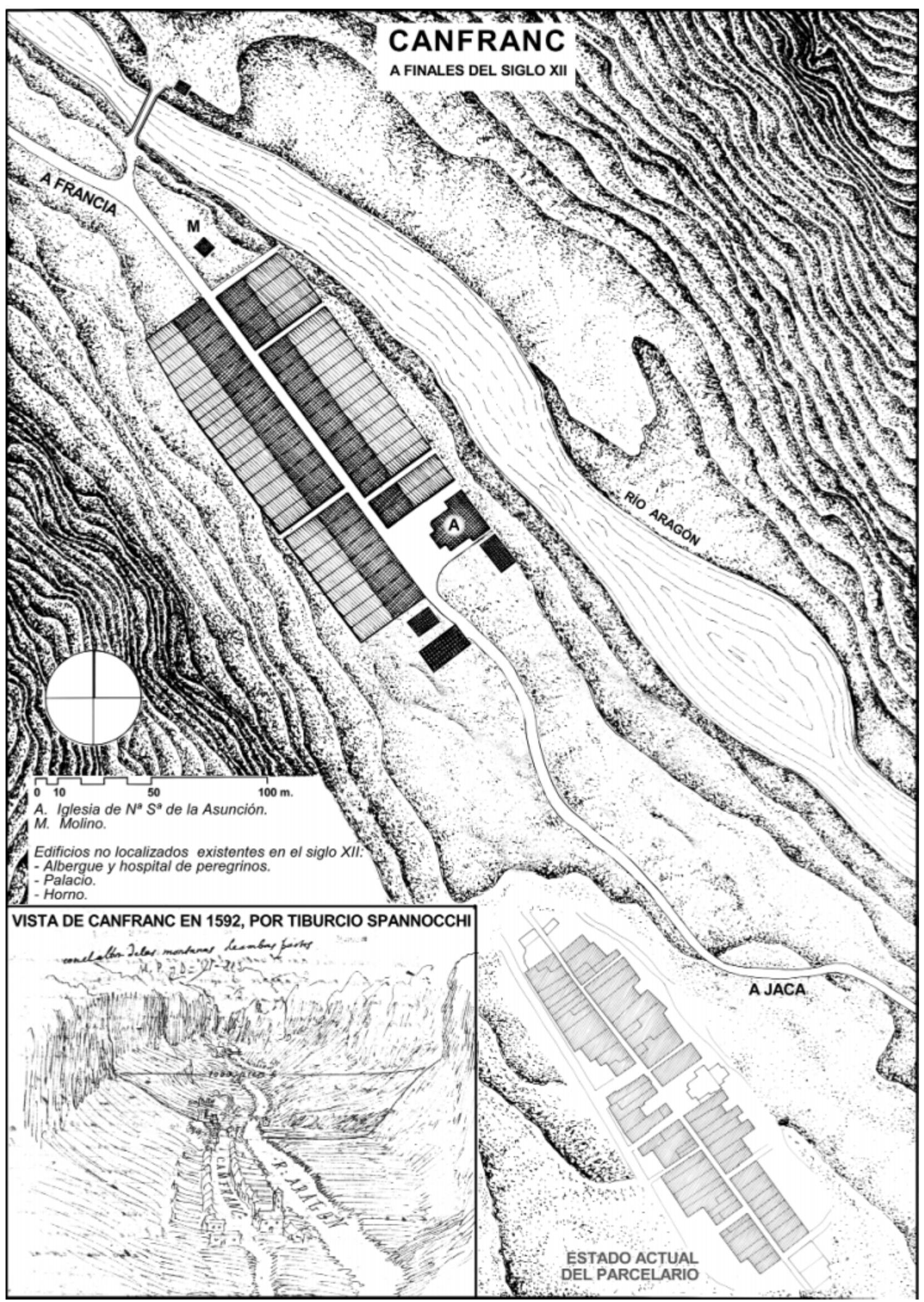

Lam. 4. Las primeras ciudades regulares en Aragón. Canfranc. 


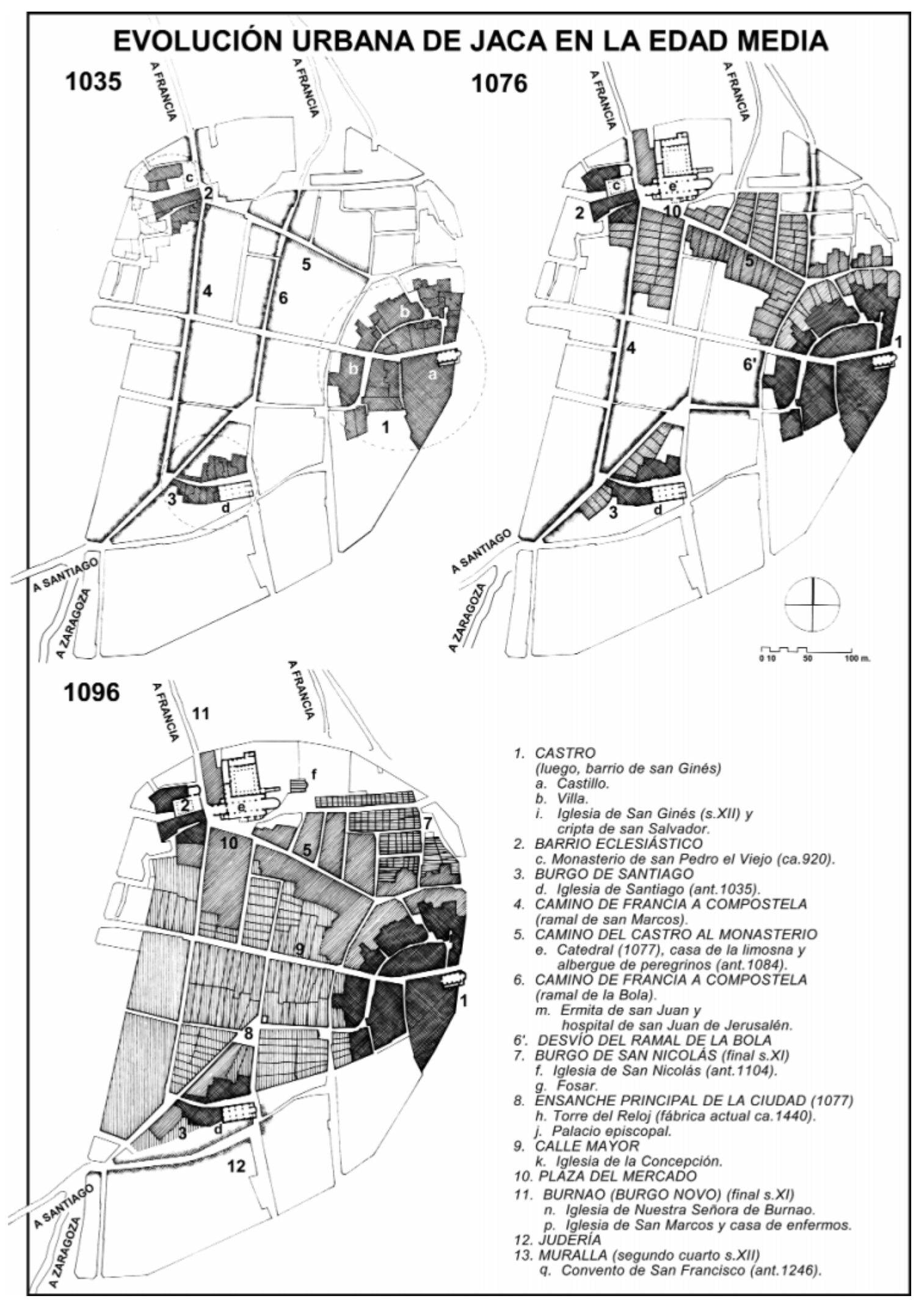

Lam. 5. Las primeras ciudades regulares en Aragón. Evolución urbana de Jaca. 


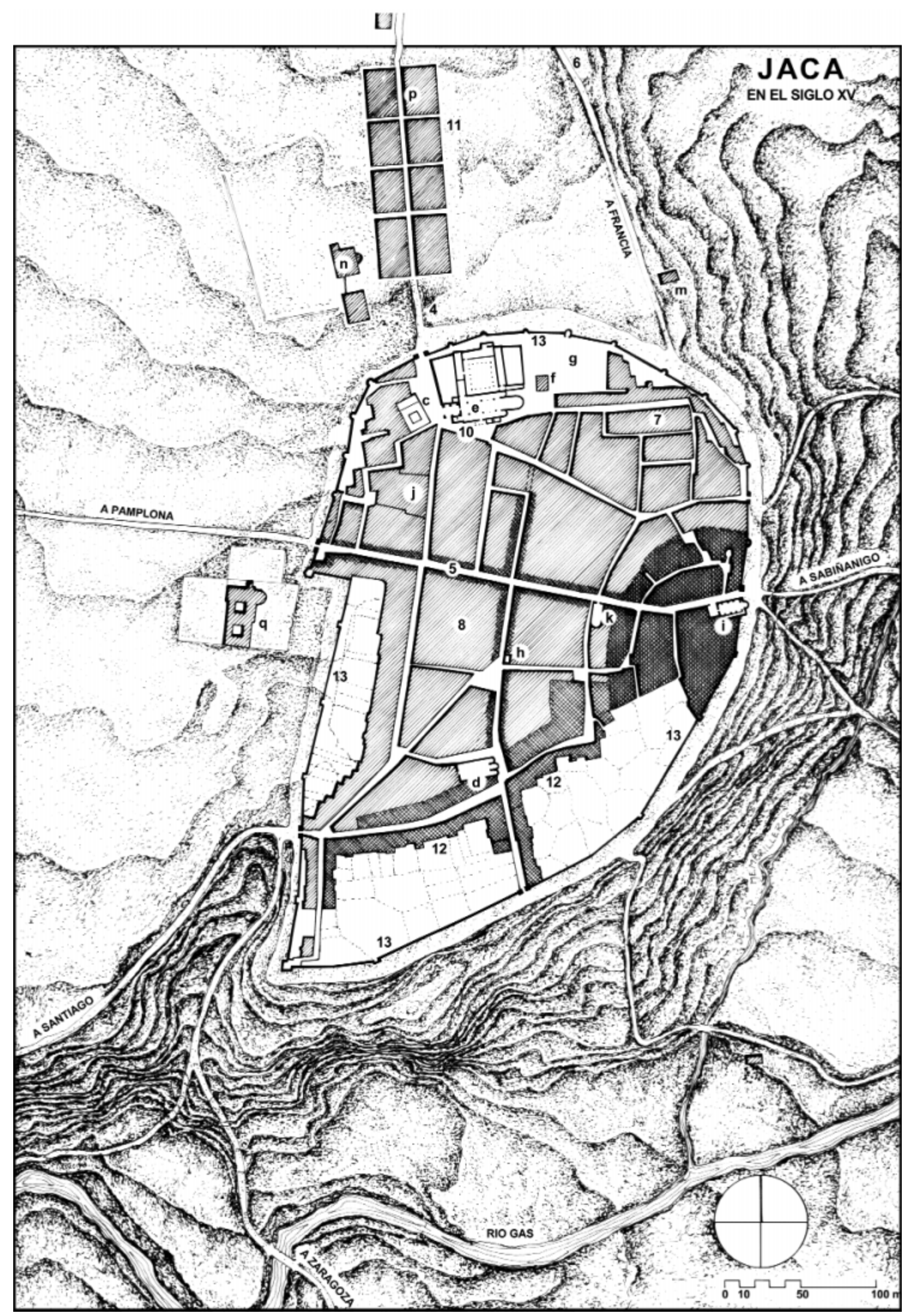

Lam. 6. Las primeras ciudades regulares en Aragón. Jaca en el siglo XV. 


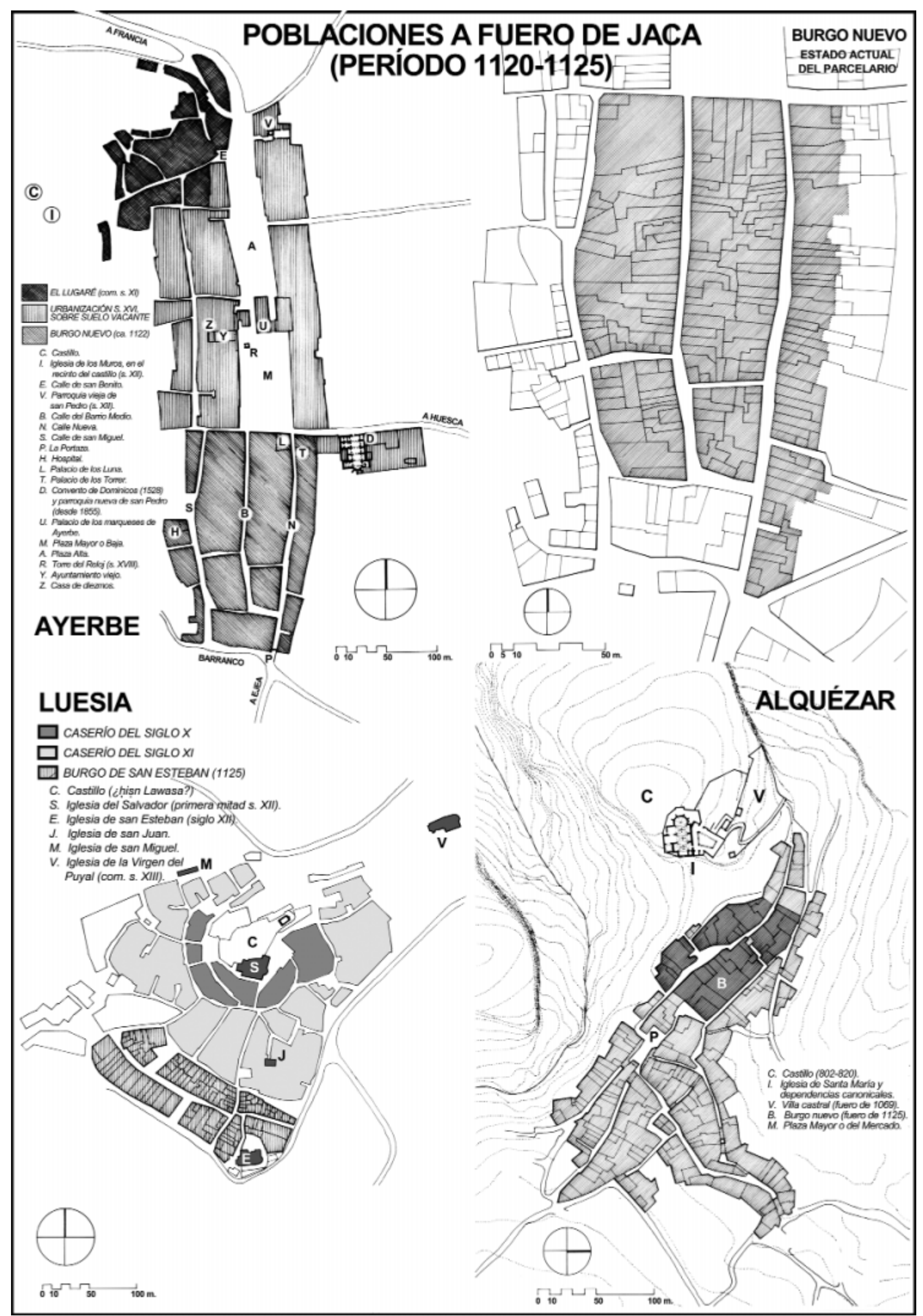

Lam. 7. Las primeras ciudades regulares en Aragón. Poblaciones a fuero de Jaca ( / | 20- / | 25). 


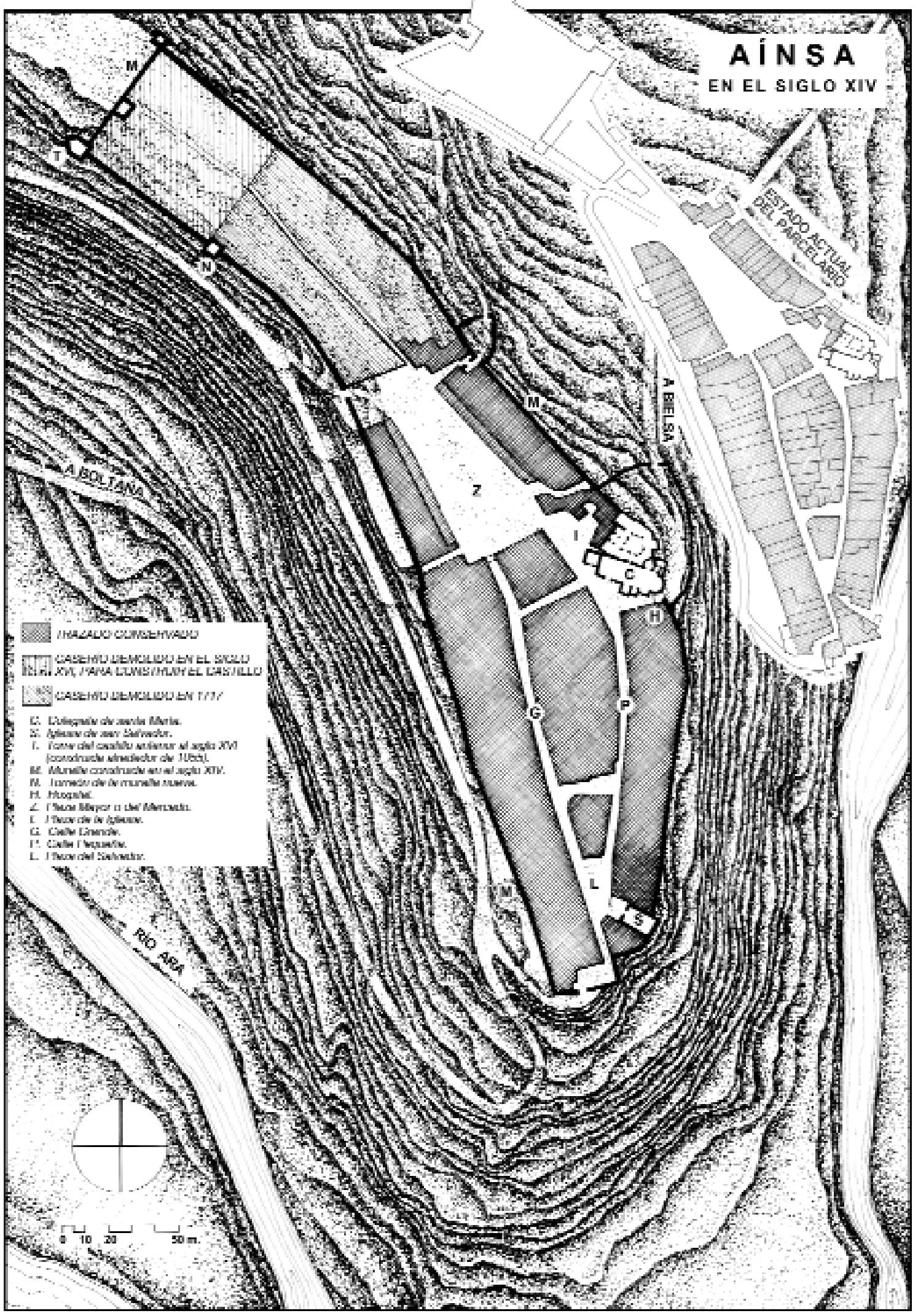

Lam. 8. Las primeras ciudades regulares en Aragón. Ainsa. 


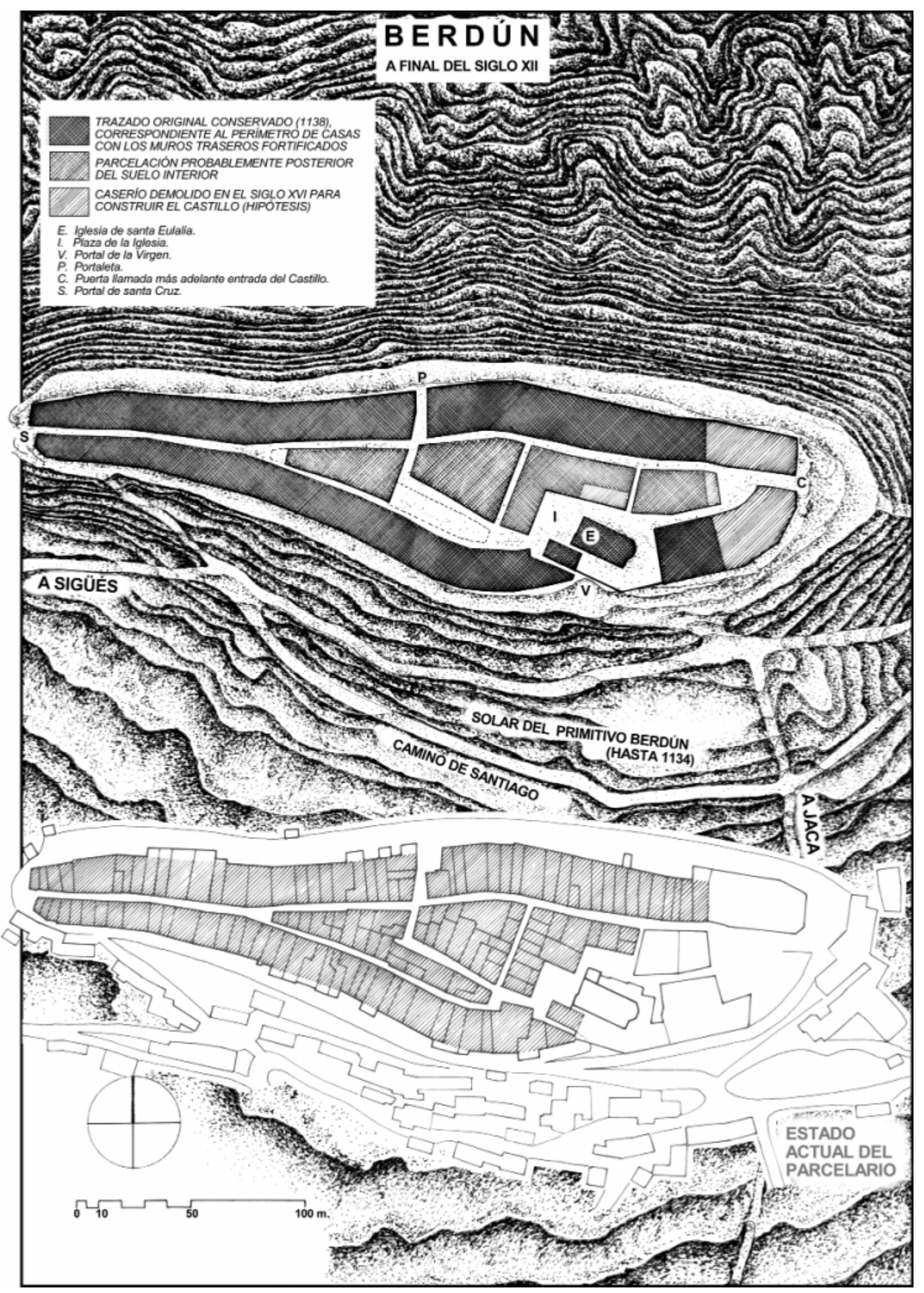

Lam. 9. Las primeras ciudades regulares en Aragón. Berdún. 


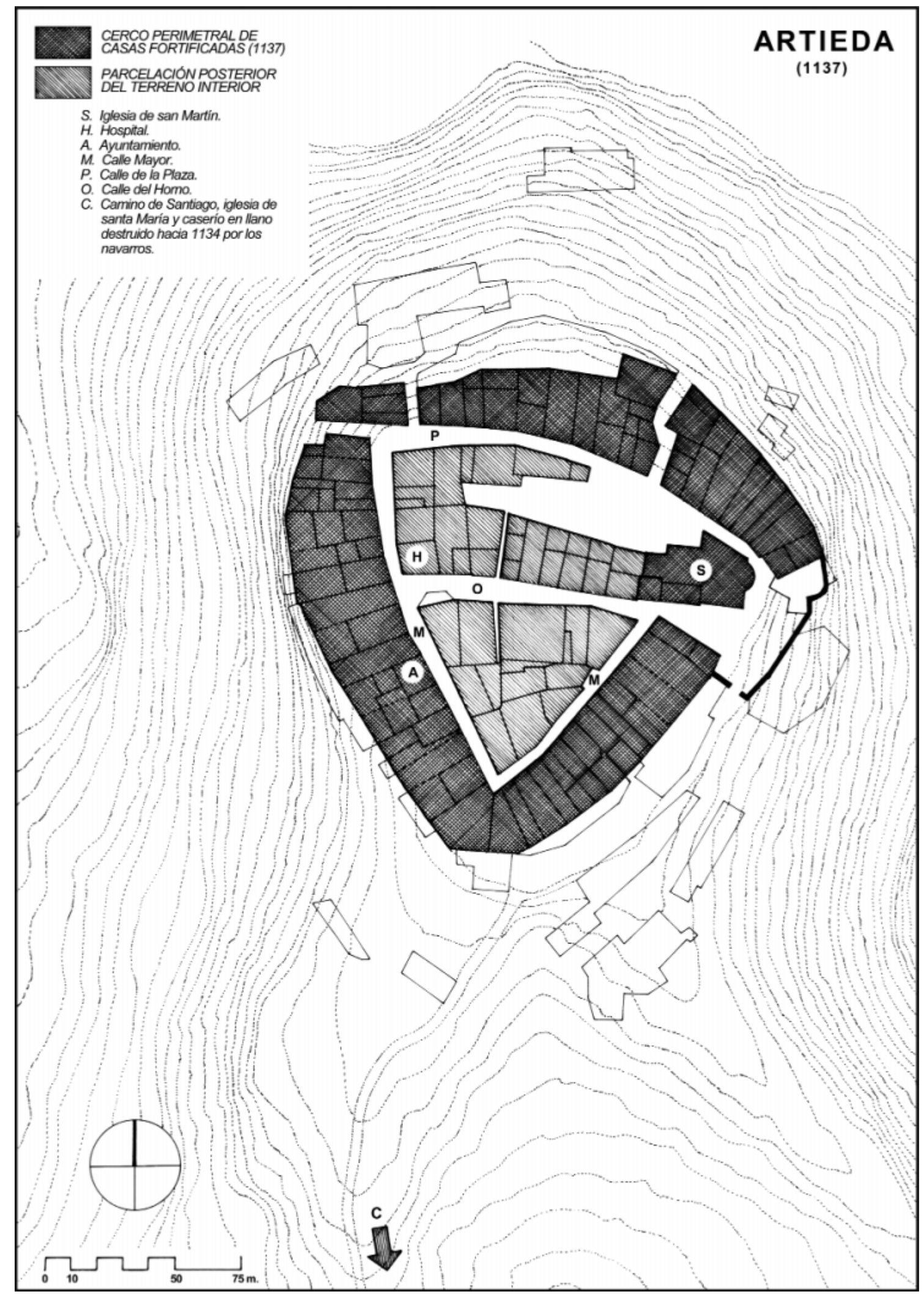

Lam. I0. Las primeras ciudades regulares en Aragón. Artieda. 


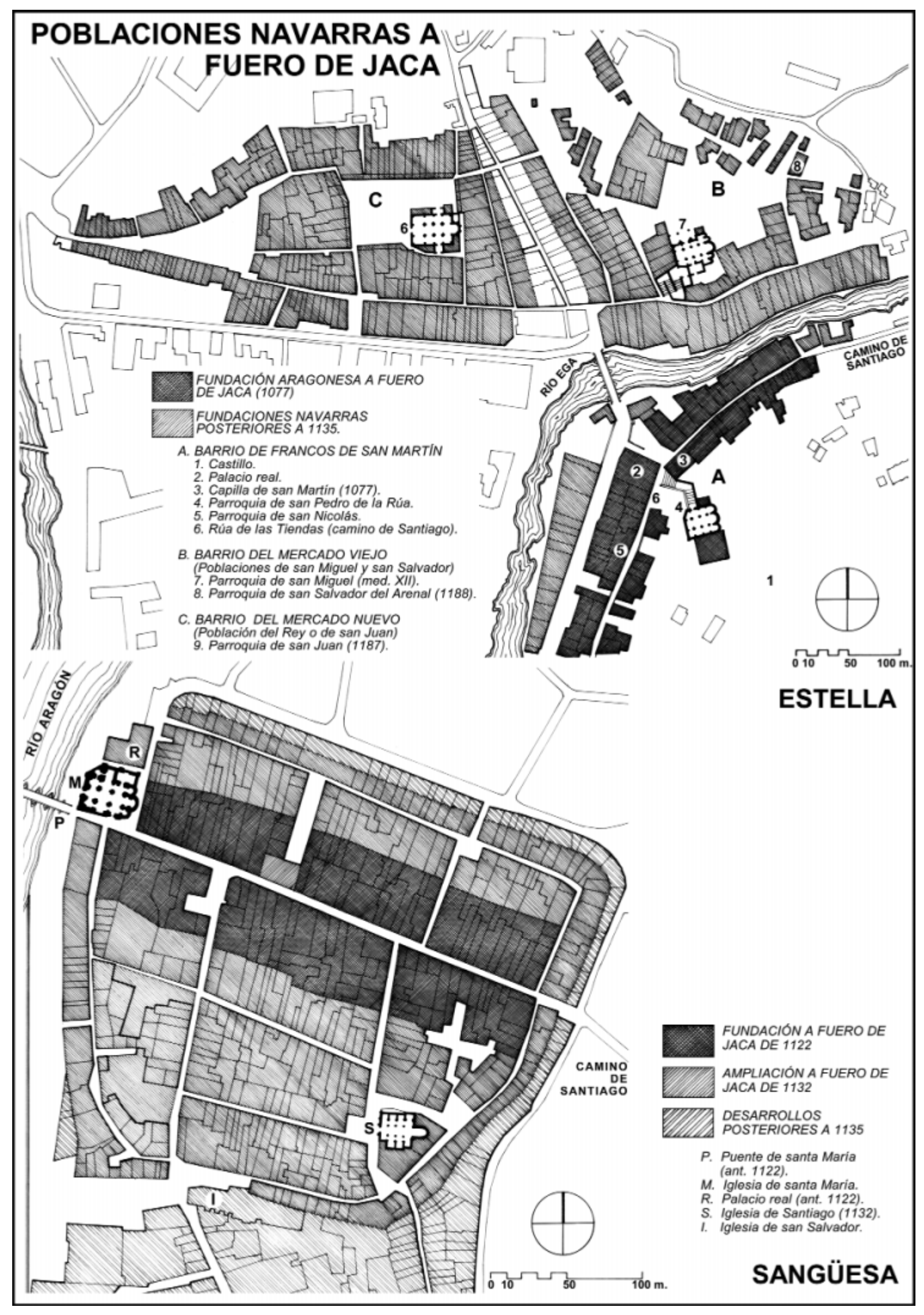

Lam. I I. Las ciudades regulares con fuero de Jaca en el Camino navarro. Estella y Sangüesa. 


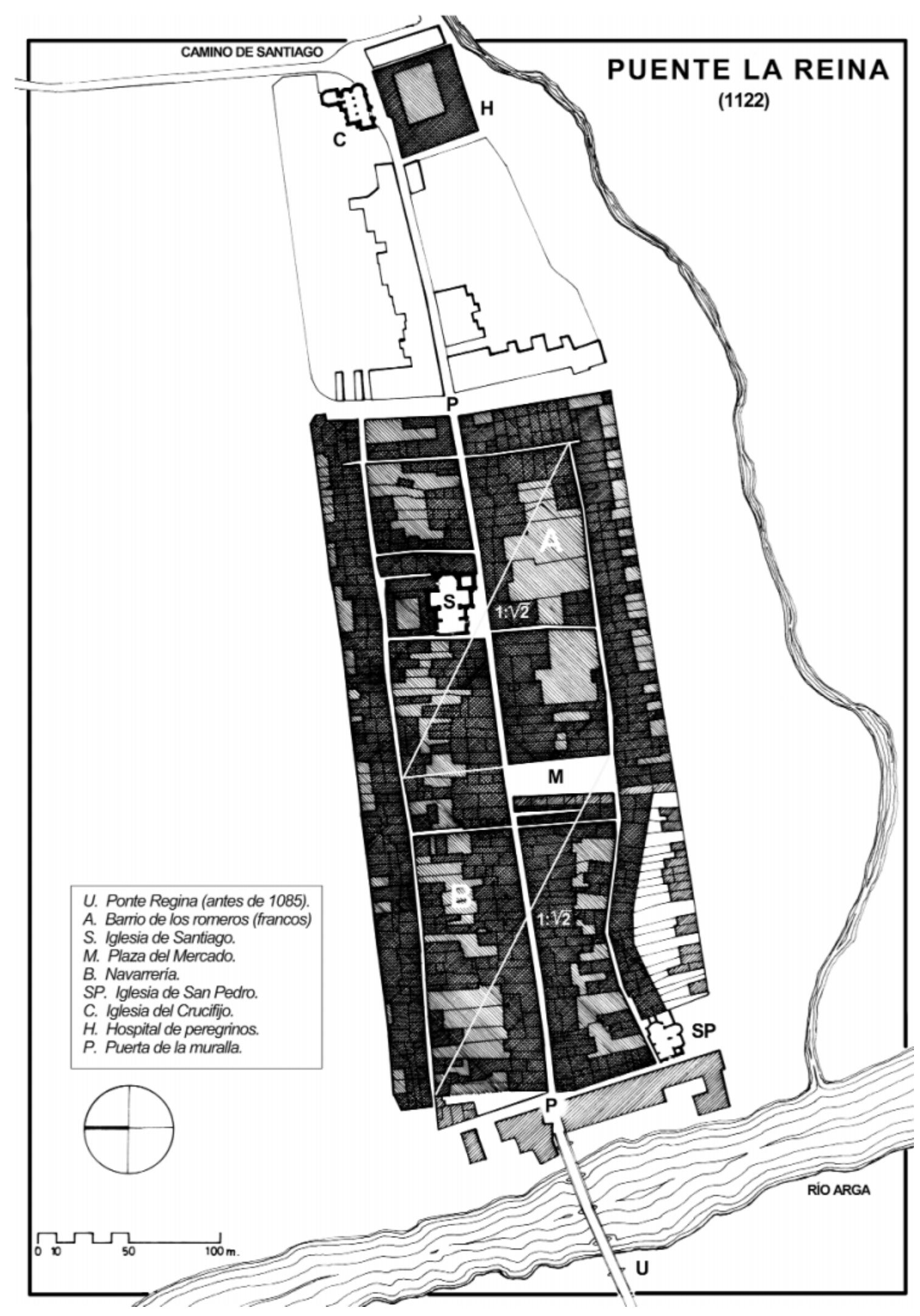

Lam. I2. Las ciudades regulares con fuero de Jaca en el Camino navarro. Puente la Reina. 


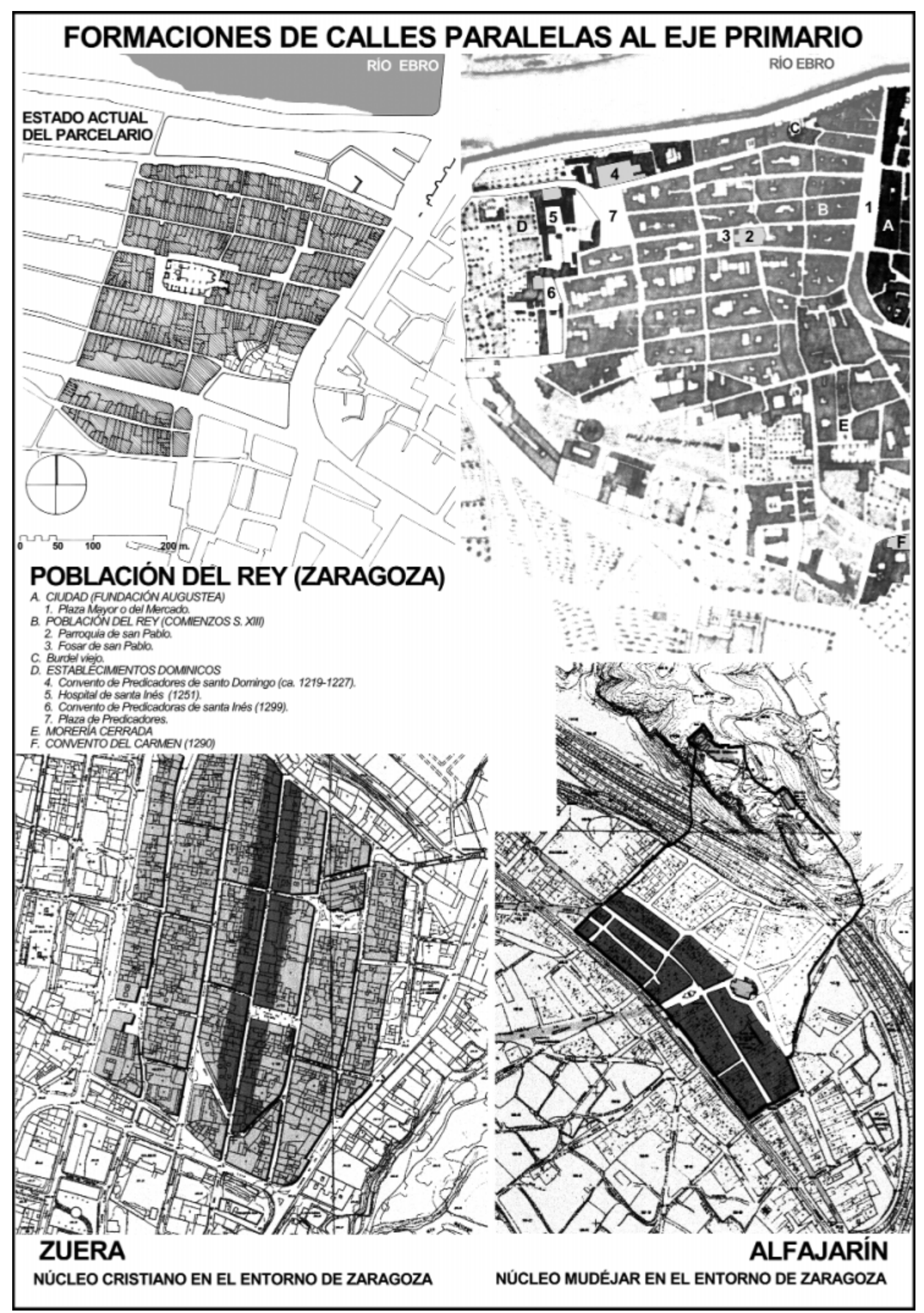

Lam. I3. Formaciones de calles paralelas al eje primario. 


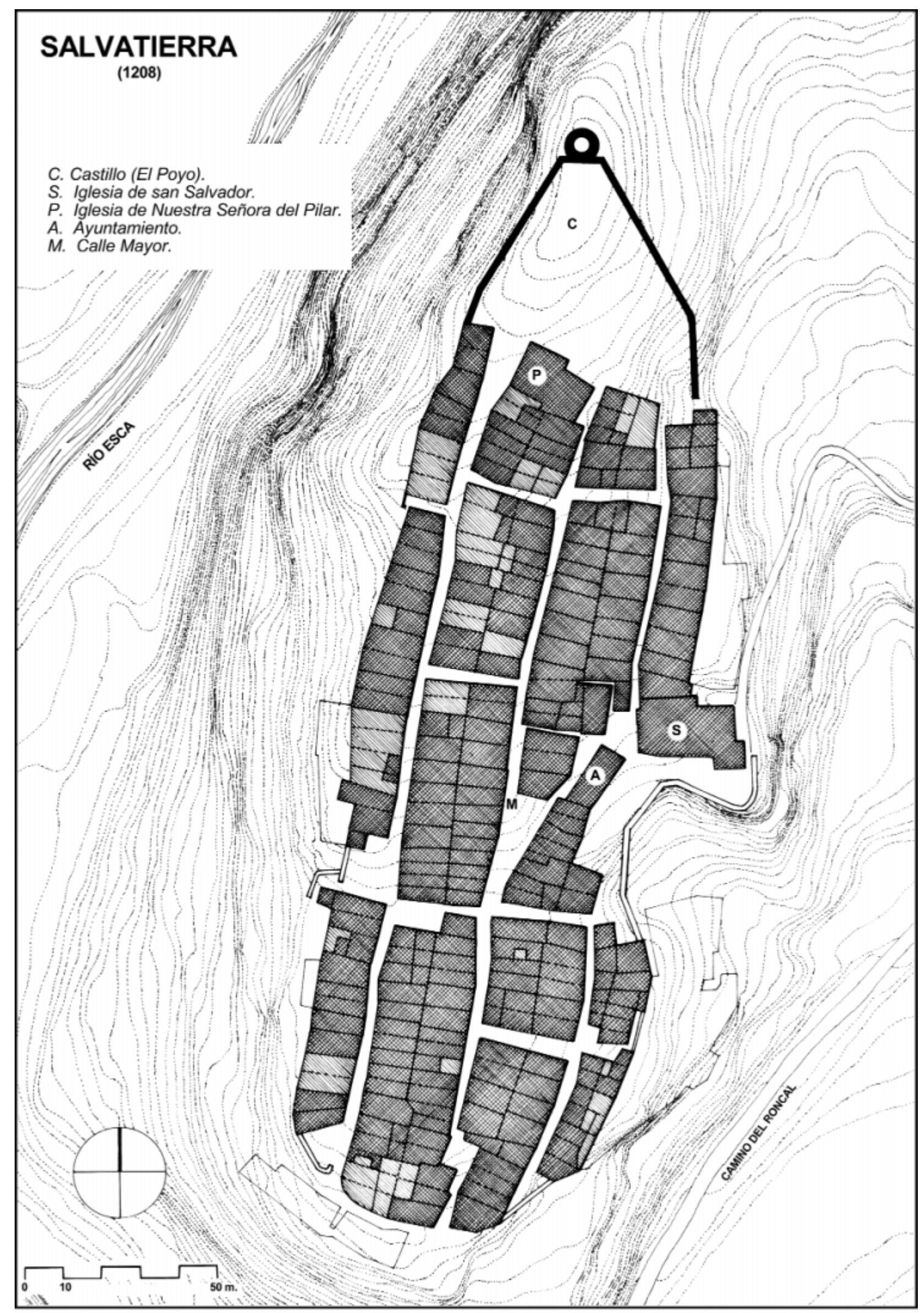

Lam. I4. Formaciones heterogéneas de fronters. Salvatierra de Esca. 


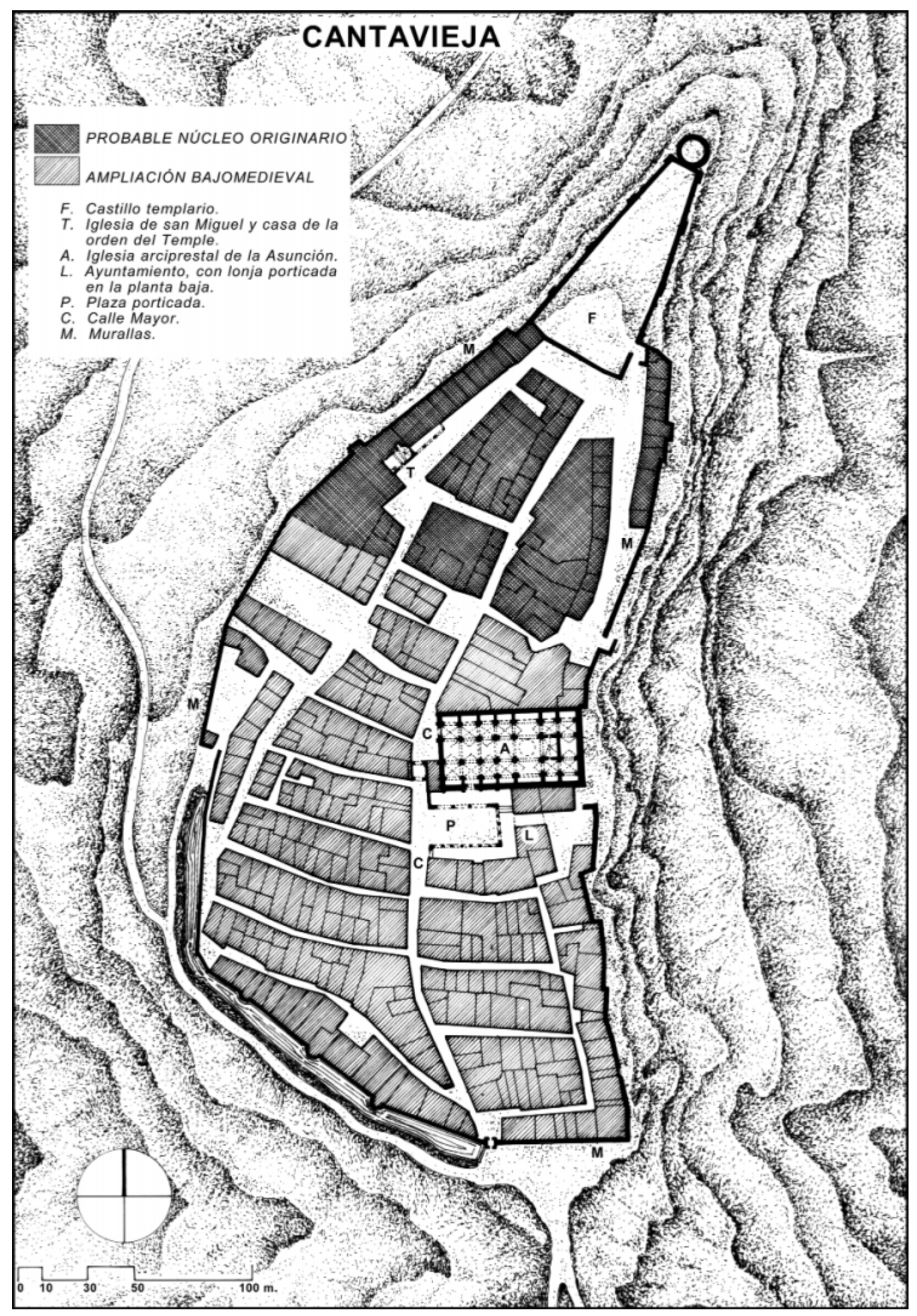

Lam. I 5. Fundaciones de las órdenes militares en el sudeste del reino. Cantavieja. 


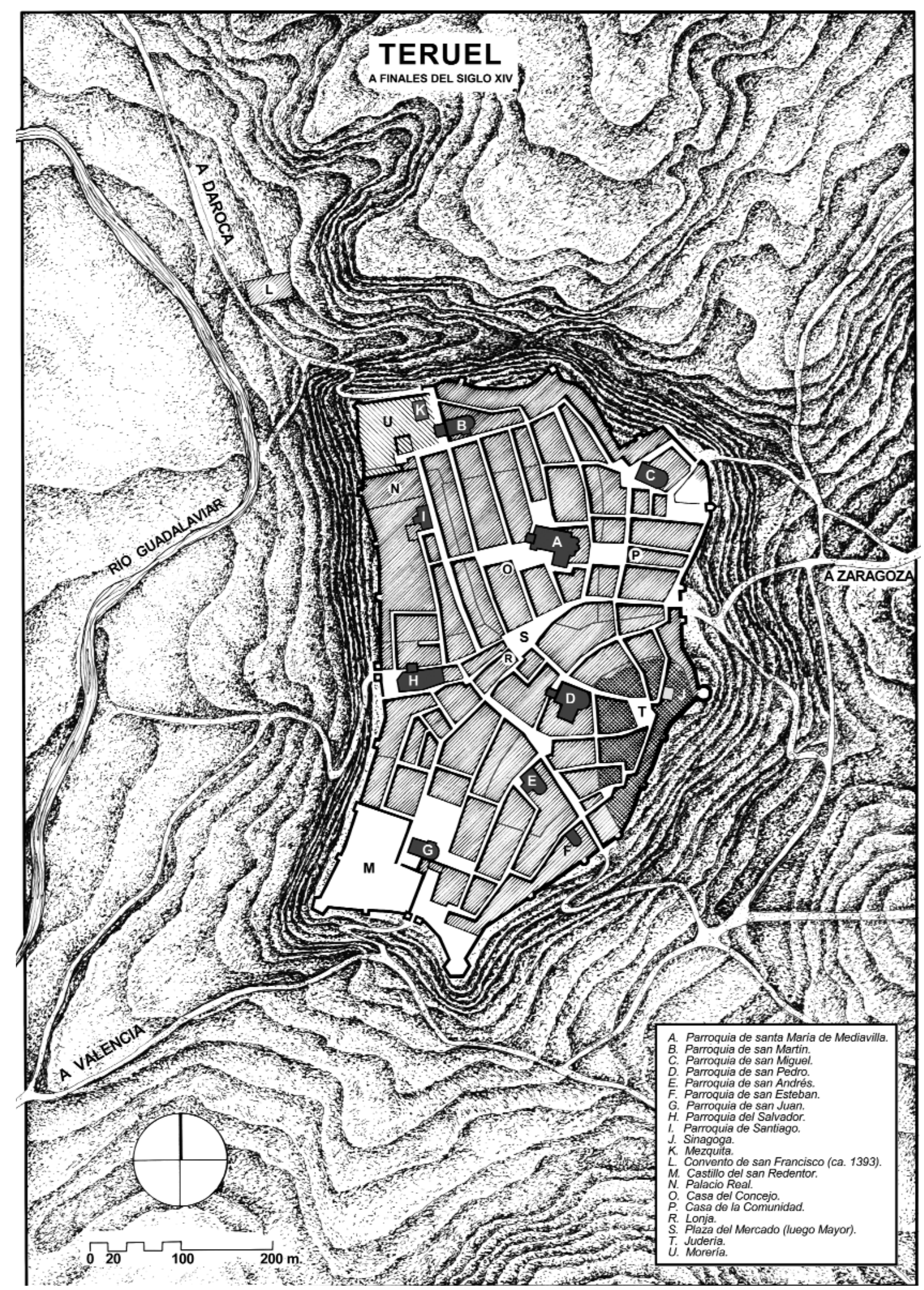

Lam. I6. Las villas concejiles. Teruel. 


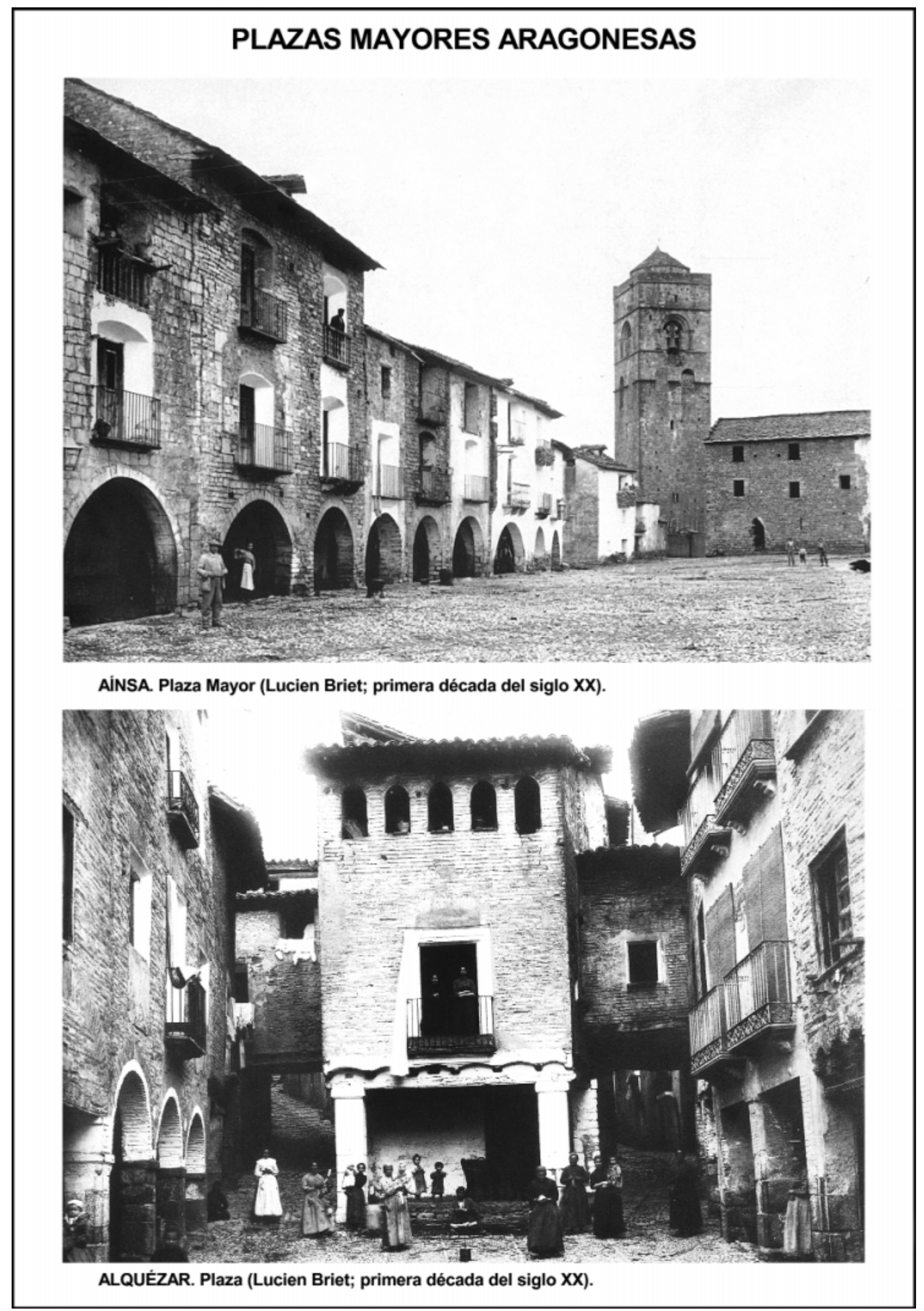

Lam. I7. El urbanismo gótico. Plazas mayores aragonesas. 


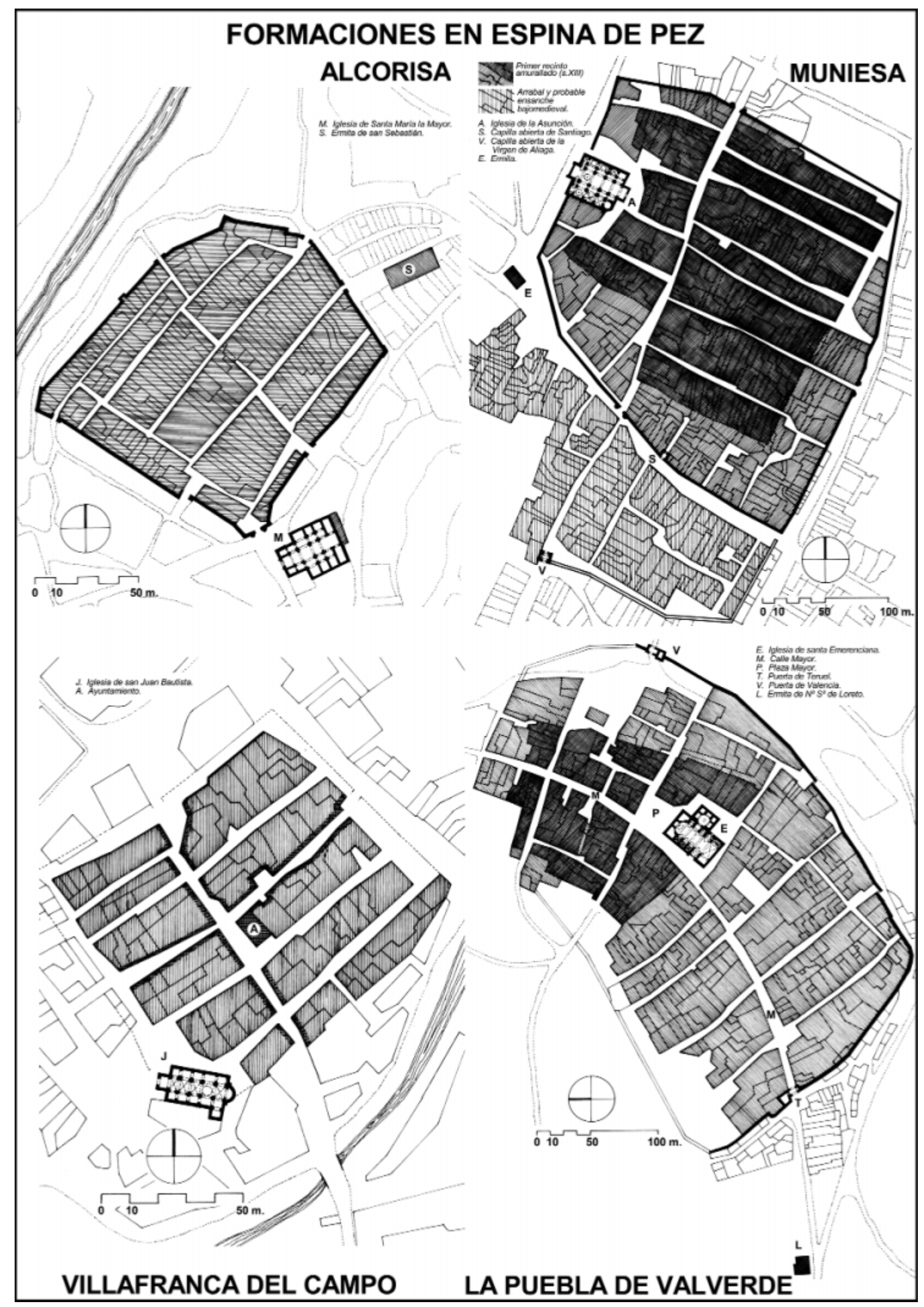

Lam. I 8. Algunos ejemplos del urbanismo gótico aragonés. Formaciones en espina de pez. 


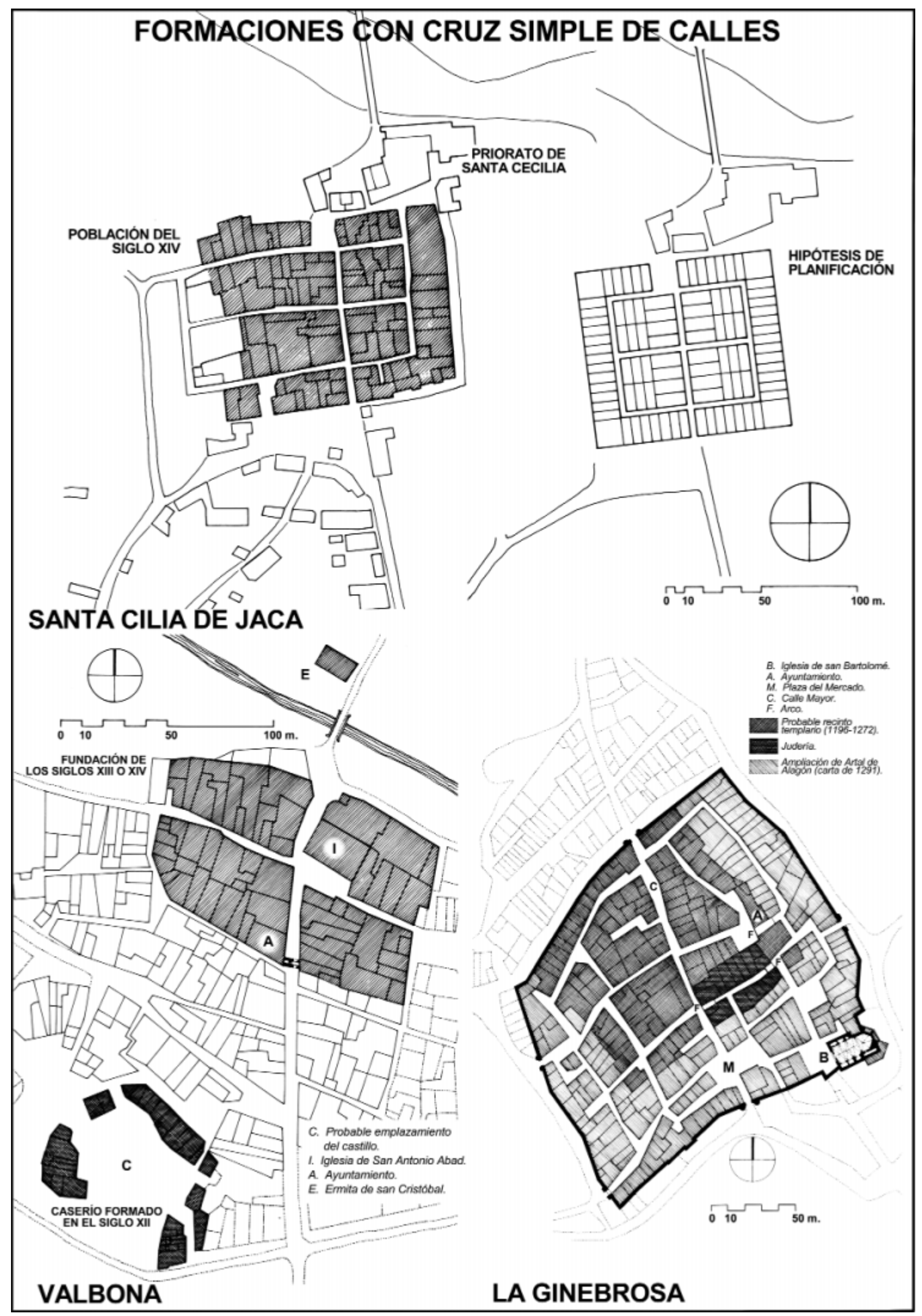

Lam. 19. Algunos ejemplos del urbanismo gótico aragonés. Formaciones con cruz simple de calles. 


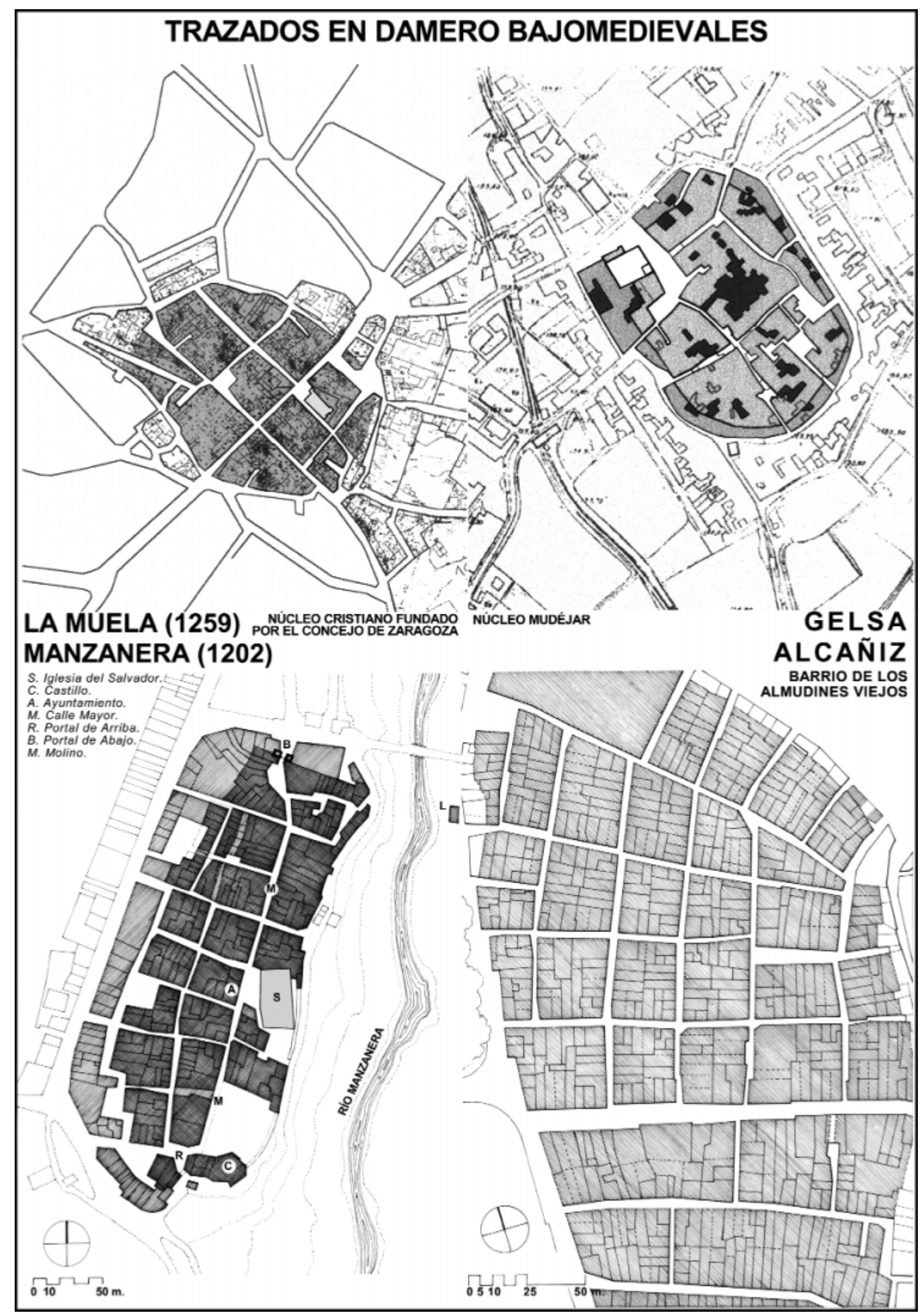

Lam. 20. Algunos ejemplos del urbanismo gótico aragonés. Trazados en damero. 


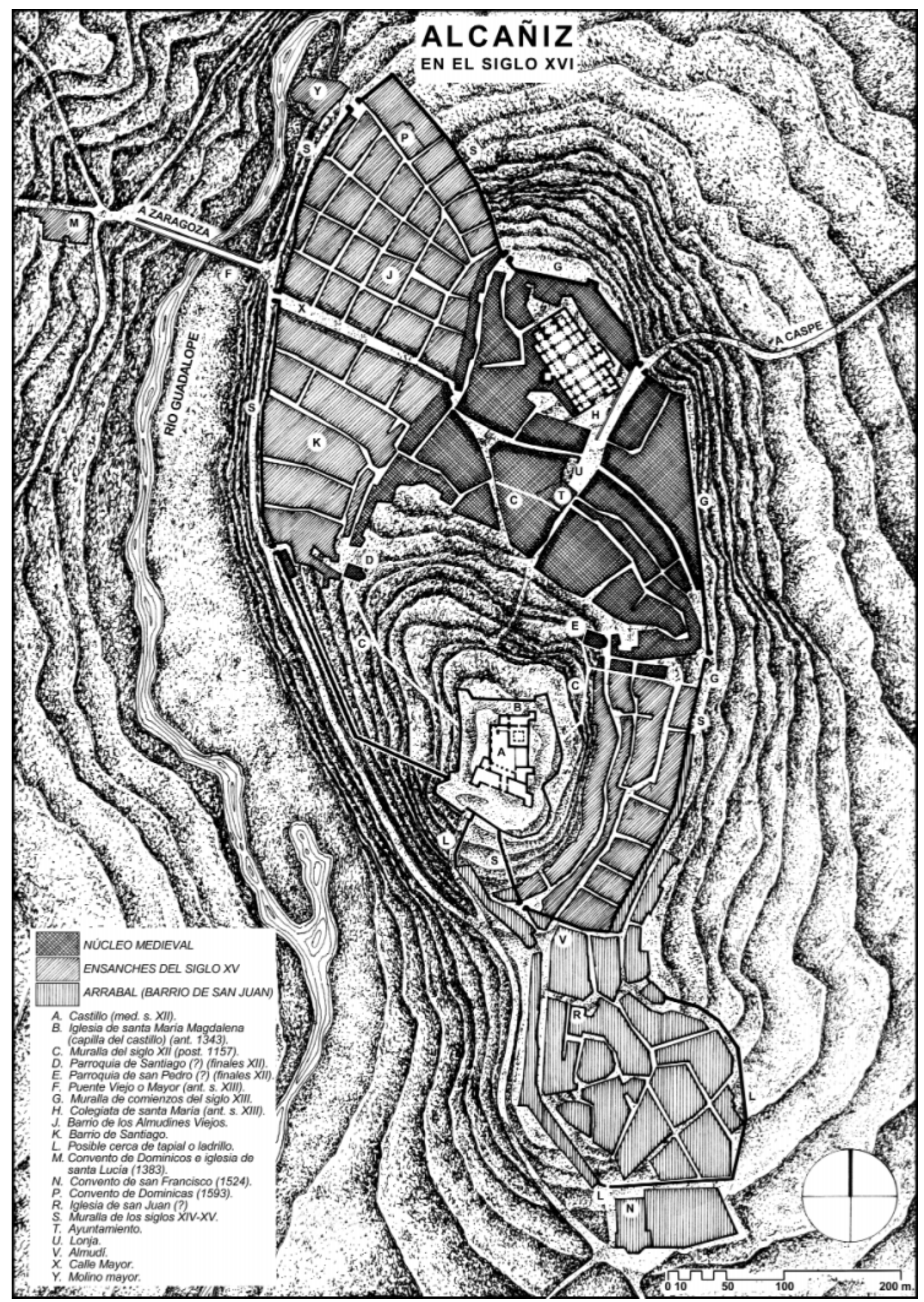

Lam. 2 I. Algunos ejemplos del urbanismo gótico aragonés. Alcañiz 


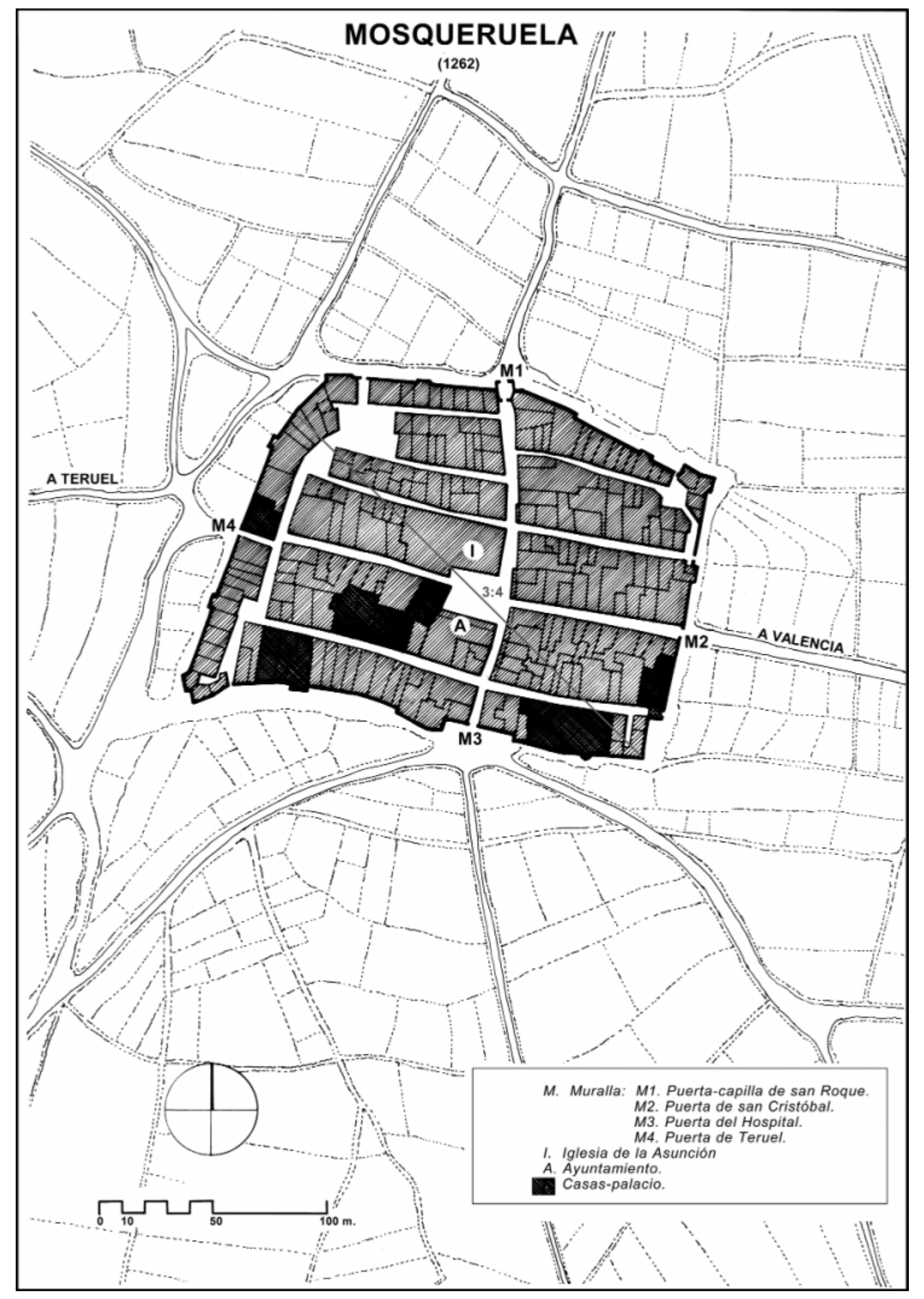

Lam. 22. Algunos ejemplos del urbanismo gótico aragonés. Mosqueruela. 


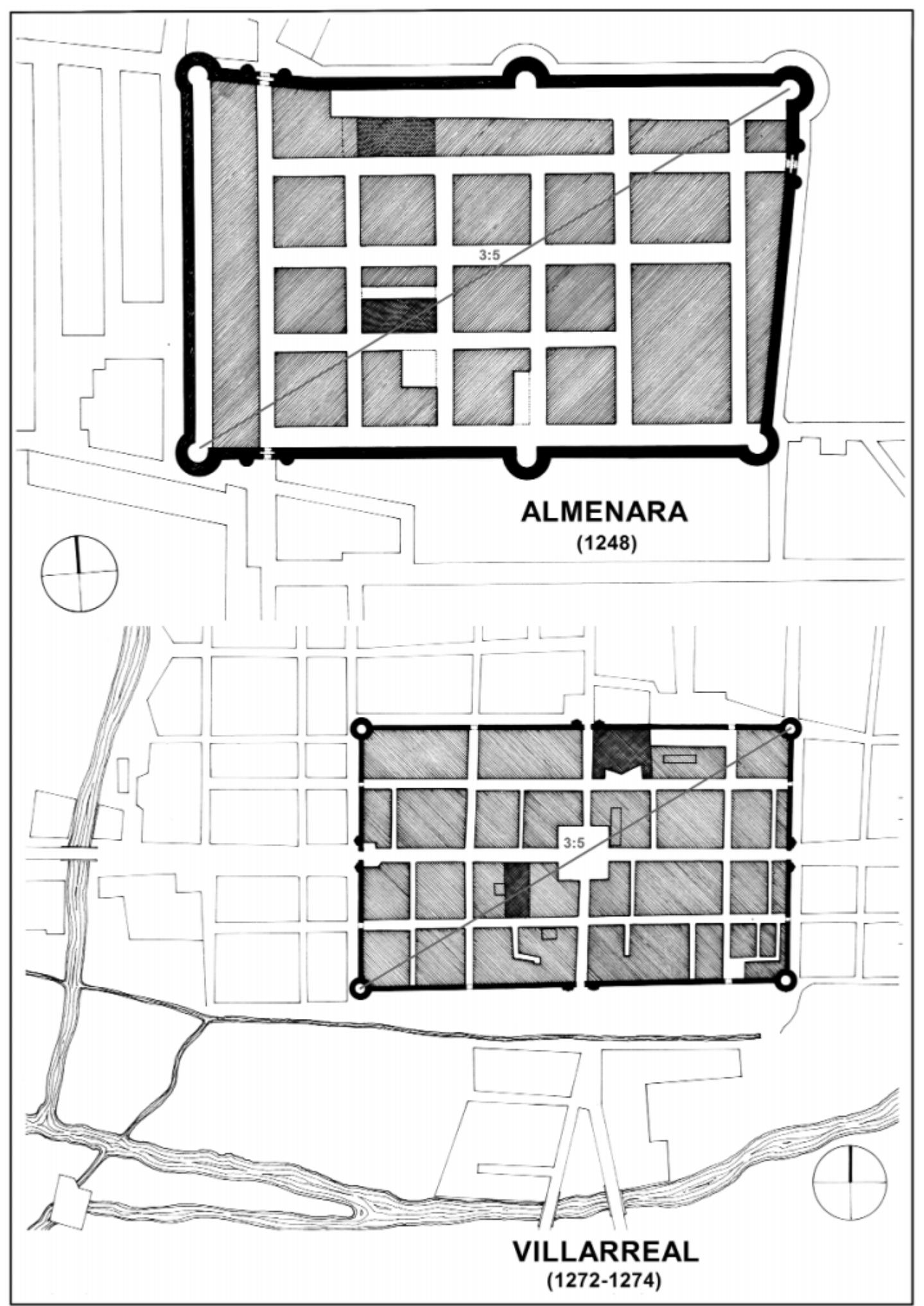

Lam. 23. Poblaciones de la Plana de Castellón, 


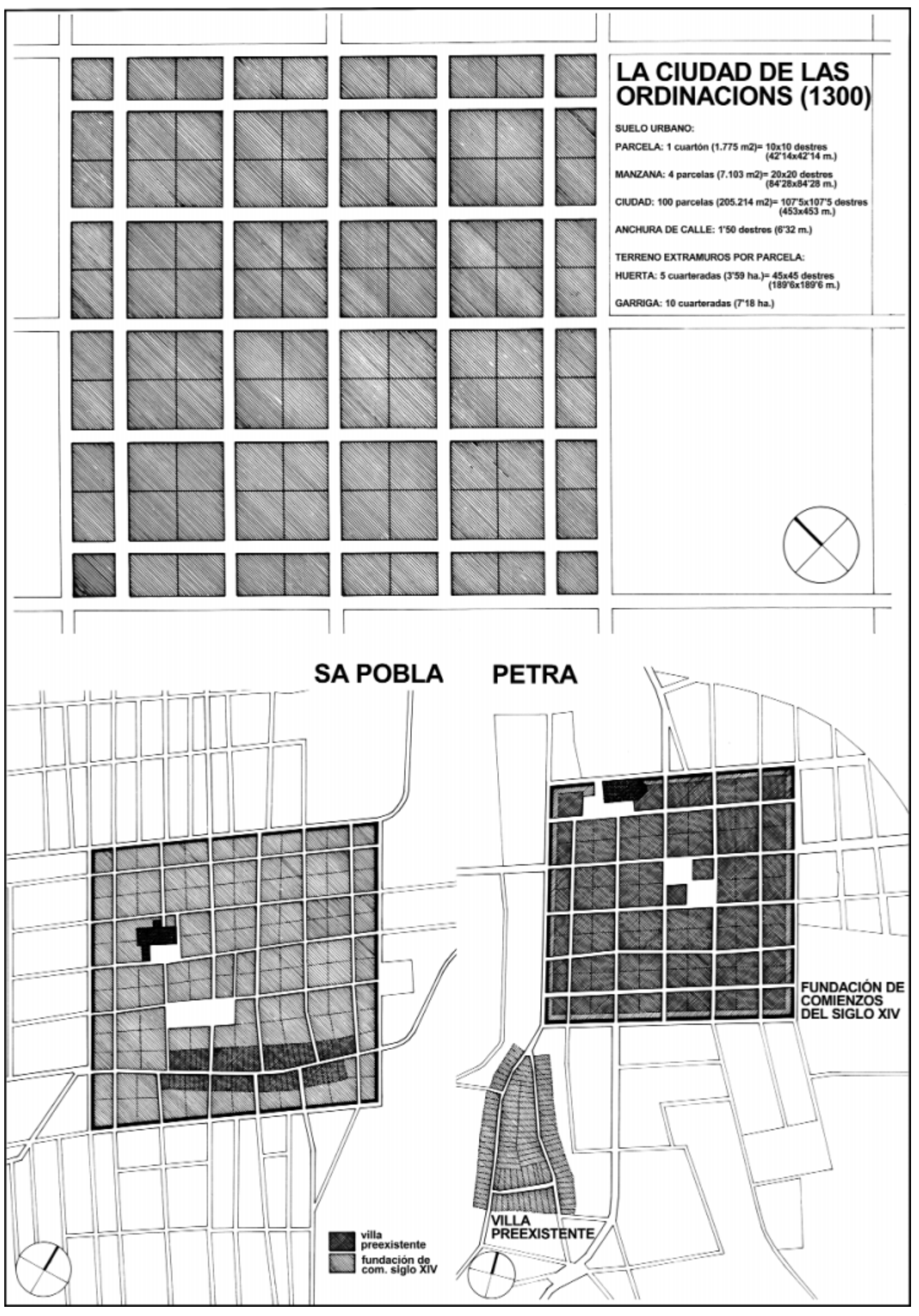

Lam. 24. Las ordenaciones de Mallorca. 


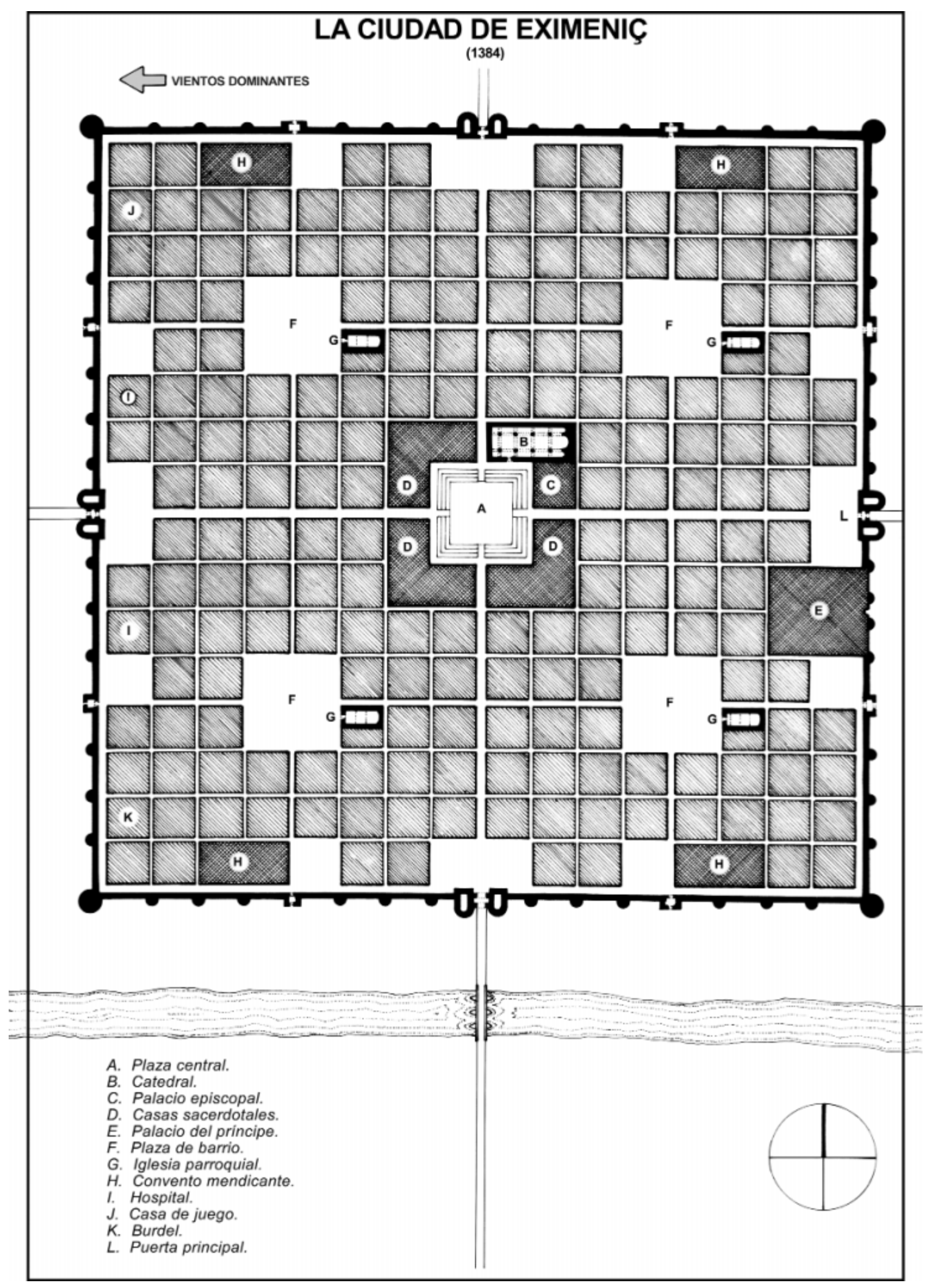

Lam. 24. La ciudad ideal de Françesch Eximeniç. 